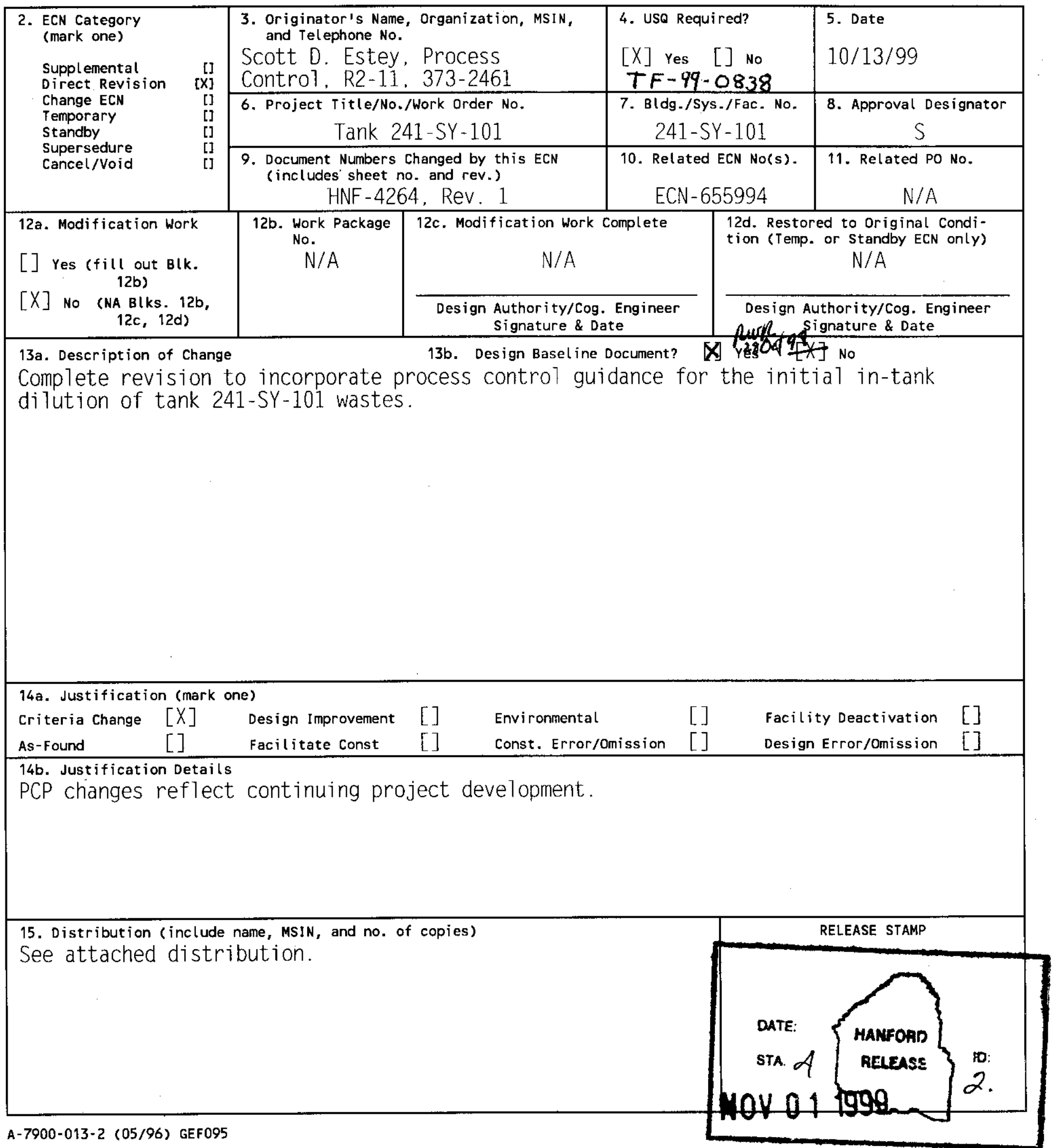




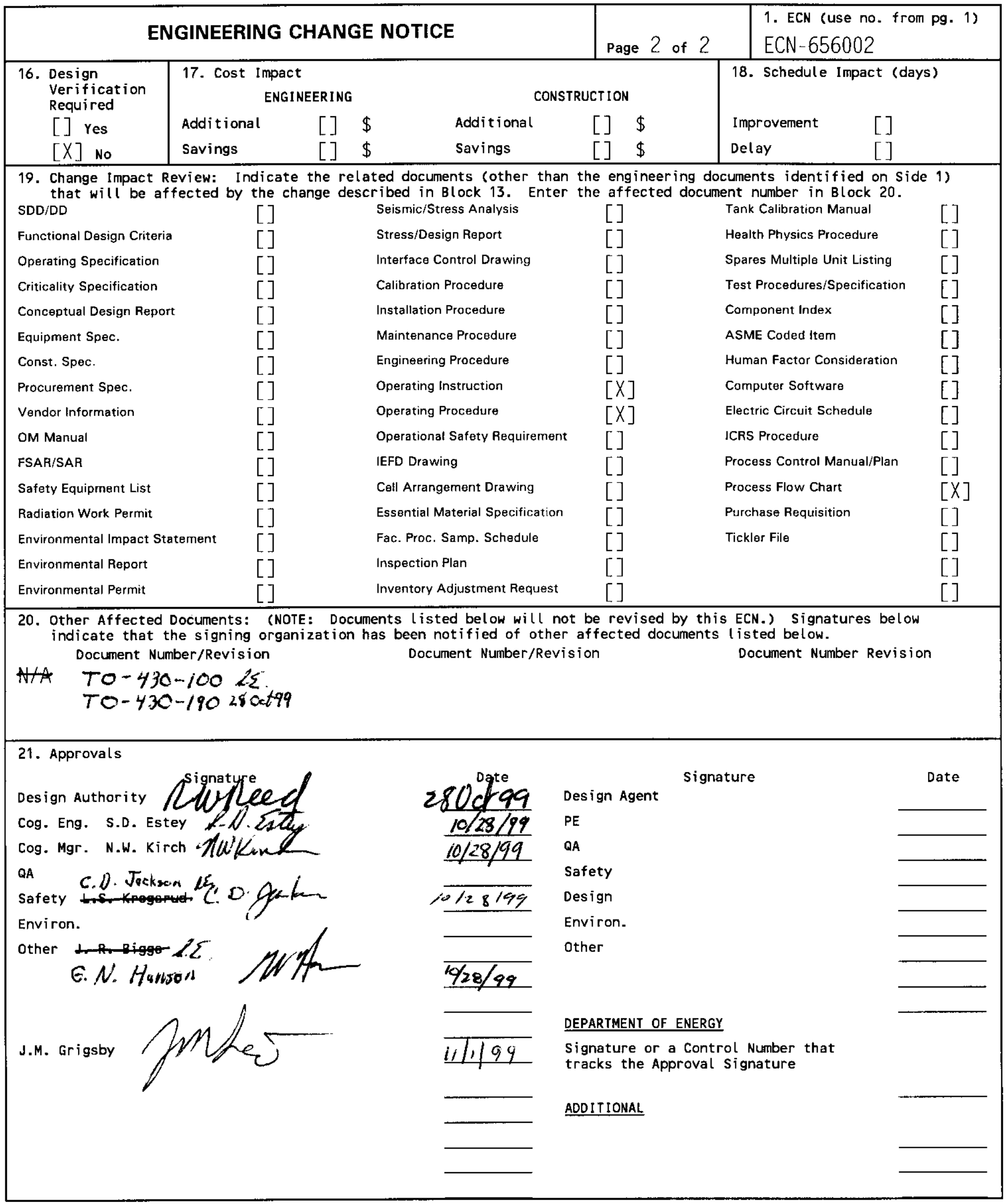




\title{
Process Control Plan for Tank 241-SY-101 Surface Level Rise Remediation
}

\author{
S. D. Estey
}

Lockheed Martin Hanford, Corp., Richland, WA 99352

$\begin{array}{llll}\text { EDT/ECN: } & \text { ECN-656002 UC: } 2070 \\ \text { Org Code: } & 74 B 50 & \text { CACN/COA: 108979/BA10 }\end{array}$

B\&R Code: EW 3120074 Total Pages: 123

Key Words: Tank 241-SY-101, Tank SY-101, SY-101, SY Farm. Mitigation. Transfer, Overground, Pump, PPP, Piping. Pump Pit. Drop Leg. New Generation Transfer Pump, NGTP, Prefabricated Pump Pit

Abstract: N/A

TRADEMARK DISCLAIMER. Reference herein to any specific comercial product, process, or service by trade name, trademark, manufacturer, or otherwise, does not necessarily constitute or imply its endorsement, recommendation, or favoring by the United States Government or any agency thereof or its contractors or subcontractors.

Printed in the United States of America. To obtain copies of this document, contact: Document Control Services, P.0. Box 950, Mailstop H6-08, Richland WA 99352, Phone (509) 372-2420; Fax (509) 376-4989.
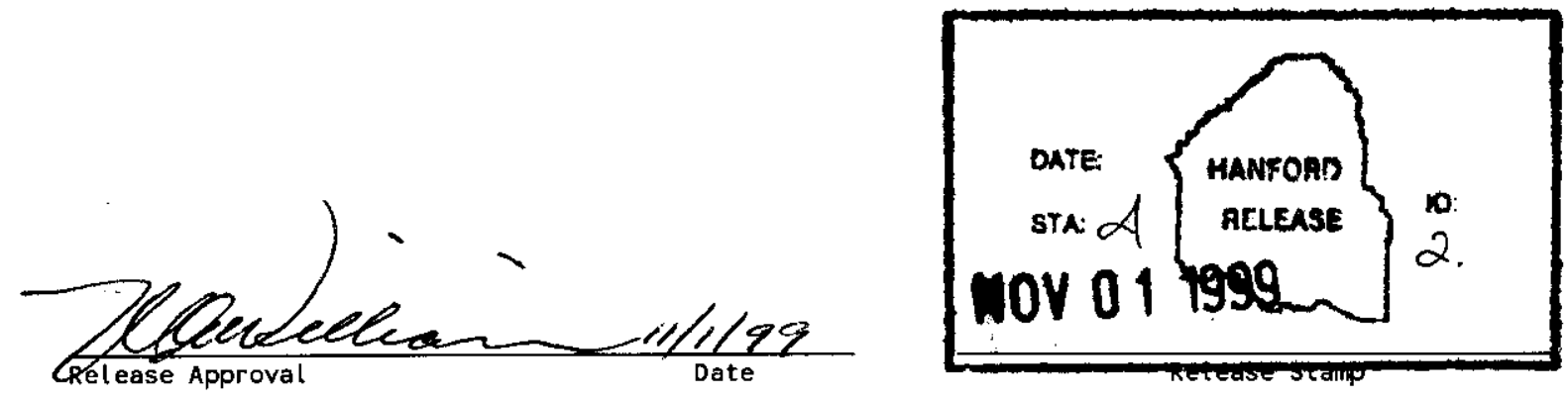

\section{Approved for Public Release}


RECORD OF REVISION

(1) Document Number

HNF-4264

Page 1

(2) Title

Process Control Plan for Tank 241-SY-101 Surface Level Rise Remediation

CHANGE CONTROL RECORD

\begin{tabular}{|c|c|c|c|}
\hline \multirow{2}{*}{ (3) Revision } & \multirow{2}{*}{ (4) Description of Change - Replace, Add, and Delete Pages } & \multicolumn{2}{|c|}{ Authorized for Release } \\
\hline & & (5) Cog. Engr. & (6) Cog. Mgr. \\
\hline 0 & $\begin{array}{l}\text { (7) Initially released } 06 / 29 / 99 \text { on EDT- } \\
611465 \text {. }\end{array}$ & S.D. Estey & N.W. Kirch \\
\hline $1 \leqslant$ & Incorporate per ECN-655994. & S.D. Este & N.W. Kirgh $9 / 28 / 9$ \\
\hline 2 RS & Incorporate per Een-6es6002. & S.D. E.XY & n.w. Kirch \\
\hline & & & \\
\hline & & & \\
\hline & & & \\
\hline & & & \\
\hline & & & \\
\hline & & & \\
\hline & & & \\
\hline & & & \\
\hline & & & \\
\hline & & & \\
\hline & & & \\
\hline & & & \\
\hline & & & \\
\hline & & & \\
\hline & & & \\
\hline & & & \\
\hline & & & \\
\hline & & & \\
\hline & & & \\
\hline & & & \\
\hline & & & \\
\hline & & & \\
\hline & & & \\
\hline & & & \\
\hline & & & \\
\hline & & & \\
\hline & & & \\
\hline ( & ( & & \\
\hline
\end{tabular}


HNF-4264

Revision 2

\title{
PROCESS CONTROL PLAN FOR TANK 241-SY-101 SURFACE LEVEL RISE REMEDIATION
}

\author{
S. D. Estey \\ Lockheed Martin Hanford Corporation
}

Date Published

November 1999

Prepared for the U. S. Department of Energy

Assistant Secretary for Environmental Management

Project Hanford Management Contractor for the

U.S. Department of Energy under Contract DE-AC06-96RL13200

Approved for public release; distribution is unlimited 


\section{TABLE OF CONTENTS}

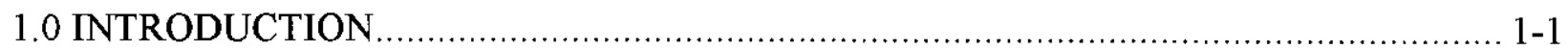

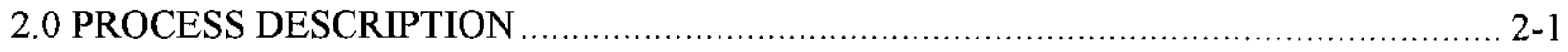

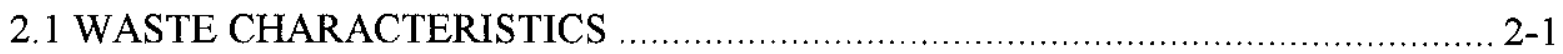

2.1.1 Waste Solids Composition Dependence on Waste Dilution and

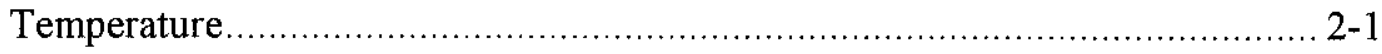

2.1.2 Waste Viscosity Dependence on Waste Dilution and Temperature................ 2-3

2.1.3 Waste Critical Velocity Dependence on Waste Dilution and Temperature ....... 2-7

2.1.4 Waste Compatibility with Tank 241-SY-102 Wastes ................................ 2-7

2.1.5 Other Waste Property Issues .............................................................. 2-8

2.2 SPECIFIC WASTE PROPERTY ISSUES FOR REMEDIATION ACTIVITIES ...... 2-9

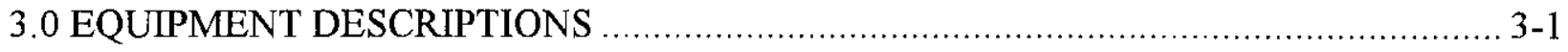

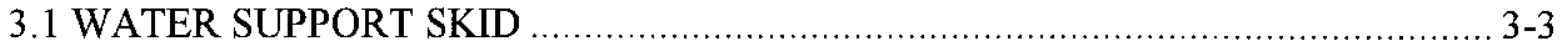

3.2 TANK 241-SY-101 PREFABRICATED PUMP PIT (PPP) AND NEW

GENERATION TRANSPER PUMP (NGTP, P-350) ..................................... 3-5

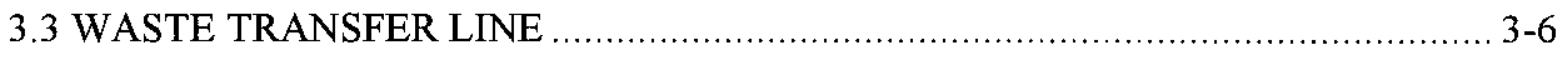

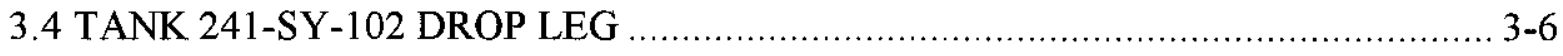

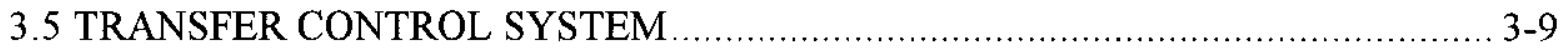

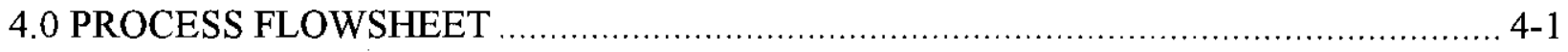

4.1 RAPID TRANSFER SYSTEM CONFIGURATION .................................... 4-3

4.2 RAPID TRANSFER SYSTEM PROCESS FLOW VALVE LINE-UPS ................. 4-5

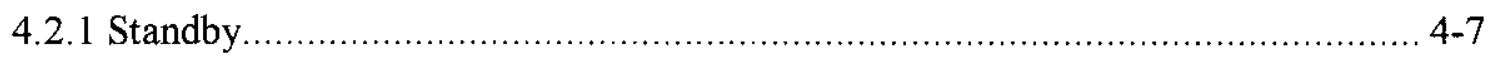

4.2.2 Transfer Line Flush ............................................................. 4-9

4.2.3 Transfer Line Back-Flush ............................................................... 4-11

4.2.4 Pump P-350 Purge .............................................................. 4-13

4.2.5 Siphon Break Flush .............................................................. 4-15

4.2.6 ACC-401 Transfer Line Flush.................................................... 4-17

4.2.7 ACC-401 Transfer Line Back-Flush .................................................. 4-19

4.2.8 Waste Transfer ..................................................................... 4-21

4.2.9 Tank Water Addition via Transfer Pump Dilution Line ............................... 4-23

4.2.10 Tank Water Addition via Transfer System Vent Line ............................. 4-25

5.0 CONTRACTOR PRUDENT CONTROLS IMPLEMENTED BY THIS PROCESS

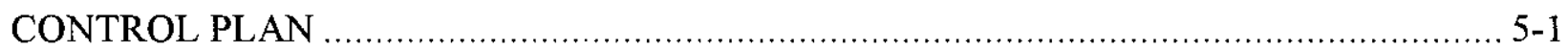


5.1 IMPLEMENTATION OF TSR AC5.12.b, MATERIAL BALANCE REQUIREMENTS

5.2 ALLOWABLE VOLUME OF WASTE TRANSFERRED OUT OF TANK 241-SY-101 $5-4$

5.3 ALLOWABLE VOLUME OF TANK 241-SY-101 DILUTION ……...................... 5-5

6.0 PROCESS CONTROL

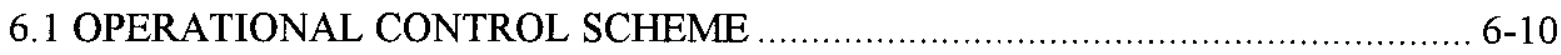

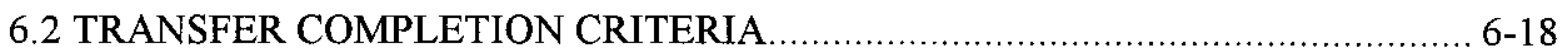

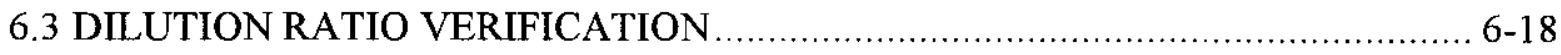

6.4 SPECIFIC OPERATING INSTRUCTIONS FOR TRANSFER ........................... 6-21

6.5 CONTROL OF TANK BACK-DILUTION ACTIVITIES …................................ $6-21$

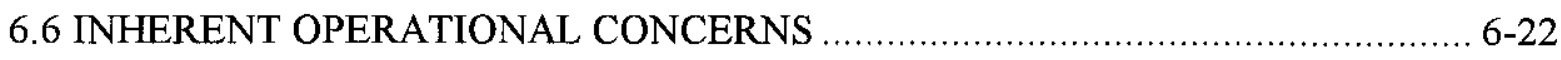

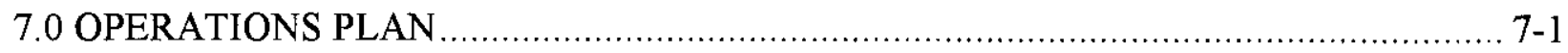

7.1 INITIAL PUMP P-350 INSTALLATION AND STANDBY LINE-UP

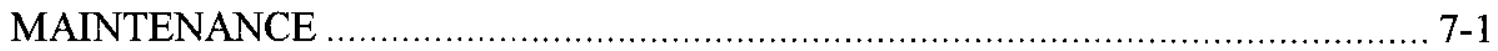

7.2 A DISCUSSION OF FLOW AND TEMPERATURE MEASUREMENT

ERROR

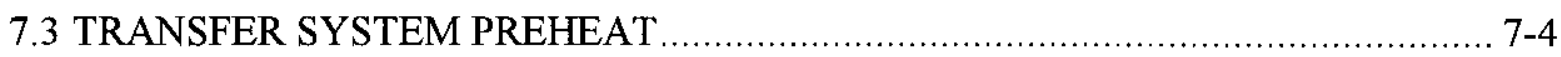

7.4 SYSTEM STARTUP MANAGEMENT PLAN _.................................................. 7-4

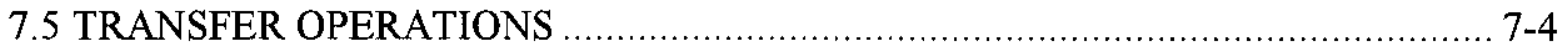

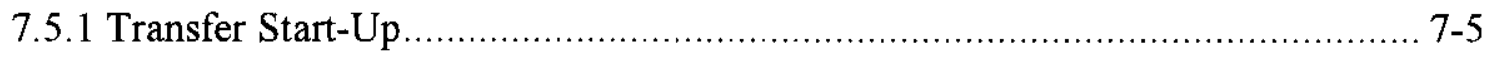

7.5.2 Controlled Transfer Shut-Down .................................................................... 7-5

7.5.3 Off-Normal Transfer Shut-Down and Flushing ........................................... 7-6

7.5.4 Tank Farm Access Considerations during Transfer Operations ....................... 7-6

7.5.5 Monitored Parameters for Transfer Operations............................................... 7-7

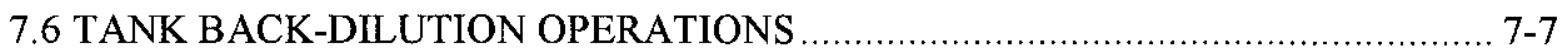

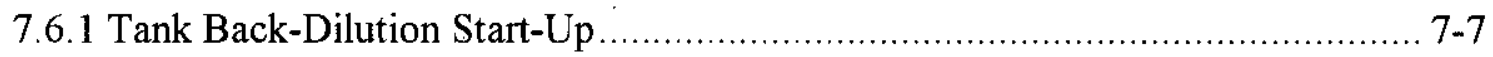

7.6.2 Tank Back-Dilution Shut-Down ................................................................. 7-8

7.6.3 Tank Farm Access Considerations during Tank Back-Dilution Operations....... 7-8

7.6.4 Monitored Parameters for Tank Back-Dilution Operations .............................. 7-8

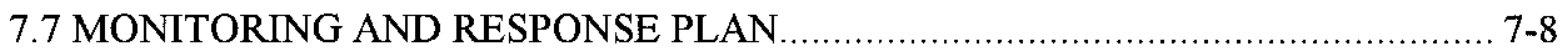

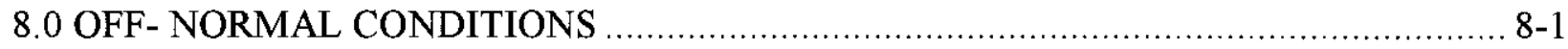

8.1 HIGH TANK HEADSPACE FLAMMABLE GAS CONCENTRATION ................... 8-1 
8.2 EXCESSIVE SY-FARM VENTILATION SYSTEM AMMONIA OR VOC

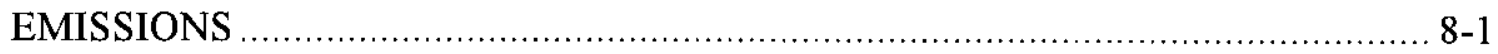

8.3 LOSS OF SY-FARM PRIMARY VENTILATION ……....................................... $8-2$

8.4 LOSS OF SY-FARM ANNULUS VENTILATION …......................................... 8-2

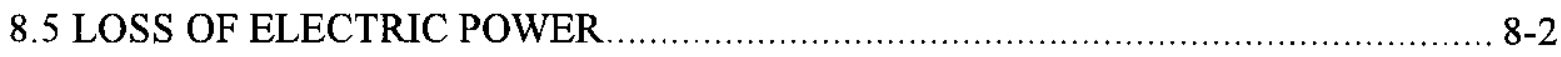

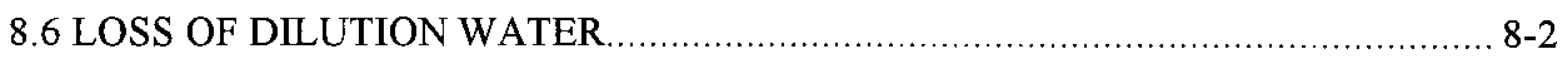

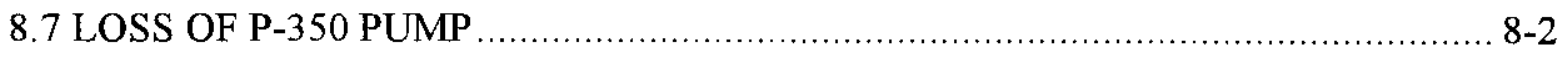

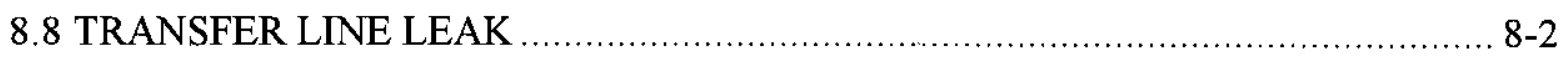

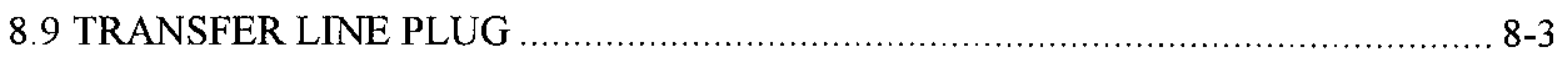

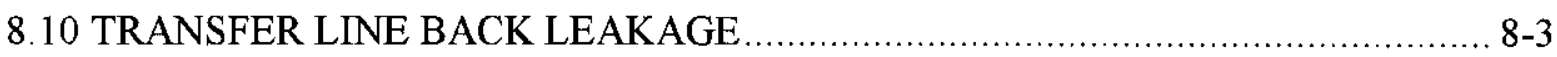

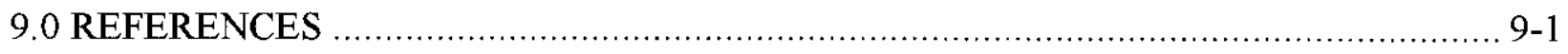

\section{APPENDICES}

APPENDIX A. INDEX OF TECHNICAL OPERATING REQUIREMENTS

\section{LIST OF FIGURES}

Figure 3-1. RAPID Transfer System Drawing List ….................................................... 3-2

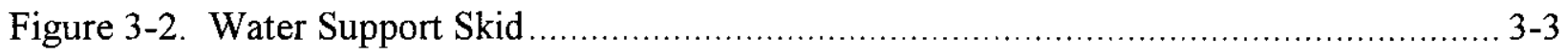

Figure 3-3. Prefabricated Pump Pit and P-350 Pump ..................................................... 3-5

Figure 3-4. Anti-Siphoning Slurry Distributor Detail ................................................. 3-8

Figure 4-1. RAPID Transfer System Process Flowsheet …….......................................... 4-2

Figure 4-2. RAPID Transfer System Schematic ........................................................... 4-3

Figure 6-1. Drawing H-14-103656,"RAPID MITIGATION SYSTEM P\&ID" ..................... 6-3

Figure 6-2. Drawing H-14-103657, "WATER SUPPORT SYSTEM P\&ID" ......................... 6-4 


\section{LIST OF TABLES}

Table 2-1. In-Situ Tank 241-SY-101 Apparent Viscosity ................................................... 2-5

Table 2-2. In-Situ Tank 241-SY-101 Physical Properties .................................................... 2-5

Table 2-3. In-Situ Tank 241-SY-101 Apparent Viscosity ……....................................... 2-6

Table 2-4. Slurry Viscosity Behavior at $120^{\circ} \mathrm{F}$ and $50 \sec ^{-1}$ Shear Rate............................ 2-6

Table 2-5. Preliminary FY 1999 Core Sample Characterization ........................................... 2-8

Table 2-6. Parameters of Concern for Tank 241-SY-101 Level Growth.................................. 2-9

Table 3-1. Water Support Skid Valve Functions ............................................................... 3-4

Table 3-2. Prefabricated Pump Pit Valve Functions .......................................................... 3-6

Table 3-3. Transfer System Controls, Indications, Interlocks and Alarms ........................... 3-11

Table 4-4-1. RAPID Transfer System Valve Nomenclature ................................................ 4-4

Table 4-2. Permissible Process Limits for Waste Transfer ................................................ 4-22

Table 5-1. Material Balance for Leak Detection …….................................................. 5-2

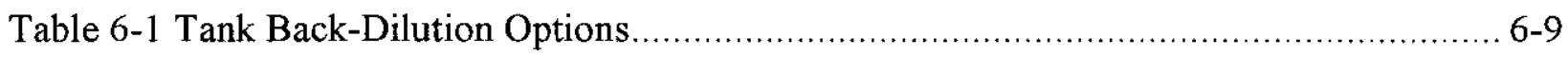

Table 6-2 Transfer System Flow Control Devices …................................................. 6-10

Table 6-3 Selected New Instrumentation for RAPID Transfer System (2 Sheets) ................. 6-10

Table 6-4. Tank 241-SY-101 Transfer System Process Control Features .............................. 6-12

Table 6-5. Flow Instrument Loops Performance Per HNF-4972 ….................................... 6-13

Table 6-6. Leak-Detection Instrument Loops Performance Per HNF-4972 ......................... 6-13

Table 6-7. Level Detection Instrument Loops Performance Per HNF-4972 .......................... 6-14

Table 6-8. Pressure Detection Instrument Loops Performance Per HNF-4972 ….................. 6-14

Table 6-9. Temperature Instrument Loops Performance Per HNF-4972 ……………......... 6-15

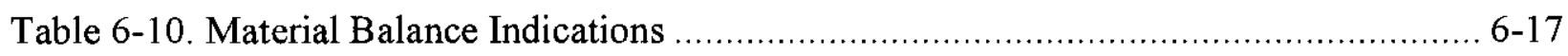

Table 7-1. Transfer System Key Process Control Variables* …….................................. 7-10 
Table 7-2. Existing SY-Farm Level Instrumentation............................................. 7-11

Table 7-3. Existing SY-Farm Gas Monitoring Instrumentation ................................... 7-12

Table A-1. Safety SSCs and TSRs and Defense-in Depth for Representative Accidents. ..... A-3

Table A-2. Operating Specification Document (OSD) Controls for Tanks 241-SY-101

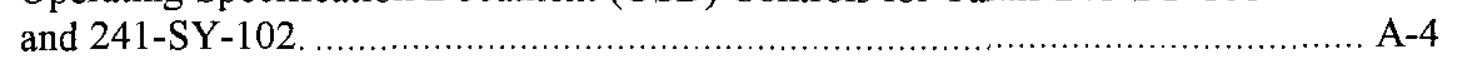

Table A-3. Industrial Safety (Tank Farm HASP) Controls for Tanks 241-SY-101 and

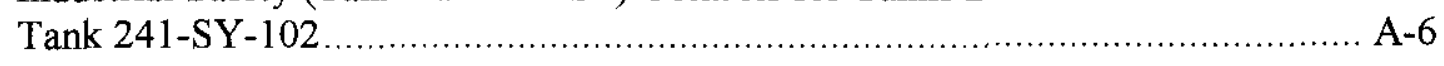




\section{LIST OF TERMS}

$\begin{array}{ll}\text { AC } & \text { Administrative Control } \\ \text { ACC } & \text { accumulator } \\ \text { ASSD } & \text { Anti-siphoning slurry distributor } \\ \text { Btu/lb } & \text { British thermal units per pound } \\ \text { Ci/yr } & \text { Curies per year } \\ \text { cP } & \text { centi-Poise } \\ \text { DACS } & \text { Data Acquisition and Control System } \\ \text { DCP } & \text { DACS control panel } \\ \text { DOE } & \text { U.S. Department of Energy } \\ \text { DOE-ORP } & \text { U.S. Department of Energy, Office of River Protection } \\ \text { DR } & \text { dilution ratio } \\ \text { DST } & \text { double-shell tank } \\ \text { EIN } & \text { equipment identification number } \\ \text { FCP } & \text { Farm Control Panel } \\ \text { FDH } & \text { Fluor Daniel Hanford, Inc. } \\ \text { FSAR } & \text { Final Safety Analysis Report } \\ \text { ft } & \text { feet } \\ \text { ft/sec } & \text { feet per second } \\ \text { FY } & \text { fiscal year } \\ \text { gal } & \text { gallon } \\ \text { gm/cc } & \text { grams per cubic centimeter } \\ \text { GMS } & \text { Gas Monitoring System } \\ \text { gpm } & \text { gallons per minute } \\ \text { HP } & \text { horse power } \\ \text { ID } & \text { internal diameter } \\ \text { in. } & \text { inch } \\ \text { kg } & \text { kilogram } \\ \text { kg/gal } & \text { kilograms per gallon } \\ \text { kg/L } & \text { kilograms per liter } \\ \text { kgal } & \text { kilogallon } \\ \text { kPa } & \text { kilo-Pascal } \\ \text { LFL } & \text { lower flammability limit } \\ \text { b } & \text { pound } \\ \text { LMHC } & \text { Lockheed Martin Hanford Corporation } \\ \text { M } & \text { molar } \\ \text { MCC } & \text { Motor Control Center } \\ \text { NGTP } & \text { new generation transfer pump } \\ \text { OSD } & \text { Operating Specification Document } \\ \text { Pa } & \text { Pascal } \\ \text { P\&ID } & \text { process and instrumentation drawing } \\ \text { PCP } & \text { Process Control Plan } \\ \text { PCV } & \text { Pressure control valve } \\ \text { PFD } & \\ \text { ppm } & \end{array}$




$\begin{array}{ll}\text { PPP } & \text { Prefabricated Pump Pit } \\ \text { PNNL } & \text { Pacific Northwest National Laboratory } \\ \text { PRV } & \text { pressure-regulating valve } \\ \text { psi } & \text { pounds per square inch } \\ \text { psig } & \text { pounds per square inch (gauge) } \\ \text { RAPID } & \text { respond and pump in days } \\ \text { sec }^{-1} & \text { per second } \\ \text { SHMS } & \text { Standard Hydrogen Monitoring System } \\ \text { SLRRP } & \text { Surface Level Rise Remediation Project } \\ \text { SOV } & \text { solenoid-operated valve } \\ \text { SpG } & \text { specific gravity } \\ \text { SSCs } & \text { structures, systems and components } \\ \text { SST } & \text { single-shell tank } \\ \text { TAP } & \text { technical advisory panel } \\ \text { TMACS } & \text { Tank Monitoring and Control System } \\ \text { TRG } & \text { Technical Review Group } \\ \text { TRU } & \text { transuranic } \\ \text { TSR } & \text { Technical Safety Requirement } \\ \text { TWRS } & \text { Tank Waste Remediation System } \\ \text { VFD } & \text { variable frequency drive } \\ \text { VOC } & \text { volatile organic compound } \\ \text { vol \% } & \text { volume percent } \\ \text { w.g. } & \text { inches water gauge } \\ \text { WSCP } & \text { water skid control panel } \\ \text { wt \% } & \text { weight percent } \\ \text { WSS } & \text { Water Support Skid } \\ { }^{\circ} \text { C } & \text { degrees Celsius } \\ { }^{\circ} \text { F } & \text { degrees Fahrenheit } \\ \% \% & \text { percent } \\ & \end{array}$




\section{HNF-4264 REV. 2}

This page intentionally left blank. 


\subsection{INTRODUCTION}

The tank 241-SY-101 transfer system was conceived and designed to address the immediate needs presented by rapidly changing waste conditions in tank 241-SY-101. Within approximately the last year, the waste in this tank has exhibited unexpected behavior (Rassat et al. 1999) in the form of rapidly increasing crust growth. This growth has been brought about by a rapidly increasing rate of gas entrapment within the crust. It has been conceived that the lack of crust agitation beginning upon the advent of mixer pump operations may have set-up a more consolidated, gas impermeable barrier when compared to a crust regularly broken up by the prior buoyant displacement events within the tank.

As a result, a series of level-growth remediation activities have been developed for tank 241-SY-101. The initial activities are also known as near-term crust mitigation. The first activity of near-term mitigation is to perform the small transfer of convective waste from tank 241-SY-101 into tank 241-SY-102. A 100 kgal transfer represents about a 10\% volume reduction allowing a $10 \%$ water tank back-dilution. Current thinking holds that this should be enough to dissolve nitrite solids in the crust and perhaps largely eliminate gas retention problem in the crust (Raymond 1999).

Additional mitigation activities are also planned on less constrained schedules. The net affect of the small transfer and follow-on mitigation activities for tank 241-SY-101 is strongly believed to be the remediation of tank $241-S Y-101$ as a flammable gas safety concern.

The process for remediating the tank will require two or more transfer/dilution cycles. Tank back-dilution will begin shortly after the initial transfer and the total dilution required to reach the final state is estimated to be between 250 to $400 \mathrm{~K}$ gallons. The final state of the waste will not require any active measures to safely store the waste and operation of the mixer pump will no longer be necessary.

The remediation activities are centered on a purpose designed and built waste transfer and dilution system. This Process Control Plan (PCP) deals with the operation of the system. To facilitate design, construction, and operation, this transfer system conveys waste from tank to tank via a transfer line composed of an overground, encased flexible hose. An existing waste transfer pump, known alternately as the new generation transfer pump (NGTP) or pump P-350, is installed in tank 241-SY-101 to accomplish the transfer. Instrumentation and control features are kept as simple as possible to facilitate the mitigation activity, yet comply with the necessary safety constraints. The design incorporates a pressurized, heated water supply to provide a high degree of operational flexibility and reliability by limiting the concentration of waste slurries in transfer. The transfer system water supply also provides the water for dilution of the waste in tank 241-SY-101. Various connections are provided to supply dilution water addition devices from the dedicated transfer system water supply. 
The Process Control Plan (PCP) provides translation of the high-level guidance and regulatory criteria and expresses it in terms of operating instructions for the waste transfer system. These controls include:

- Tank Farm Operations Administrative Controls developed in response to the U.S. Department of Energy, Office of River Protection (DOE-ORP) direction regarding supplemental controls placed upon tank 241-SY-101 surface level rise remediation activities specifically involving waste transfer activities

- Authorization Basis controls (Final Safety Analysis Report [FSAR]/Technical Safety Requirements [TSRs] and supplemental U.S. Department of Energy [DOE] direction)

- Environmental, Industrial Hygiene and Safety controls

- Operating Specification Document (OSD) controls

- Good operating practices

A current listing of these controls as identified can be found in Appendix A.

Included in this document are descriptions of tank conditions, waste conditions, major equipment, and a high-level overview of the system and the line-ups in which it operates. Primarily, the PCP addresses how the waste transfers and tank back-dilutions will be managed, defining the monitoring and control methods including material balances to determine the progress and to define completion criteria for the remediation activities.

The general concept of the waste transfers is to dilute a volume of tank 241-SY-101 wastes with an equal volume of water and to transport the combined volume to tank 241-SY-102. The water dilution is specified to minimize operational risk in the form of solids precipitation in and potential plugging of the transfer line. The waste volume in tank 241-SY-102 at the start of the transfer is in the range of 500 to $750 \mathrm{kgal}$. The anticipated waste volume in tank 241-SY-102 at transfer completion will be in the range of $700 \mathrm{kgal}$ to $950 \mathrm{kgal}$. These limits are specified to maintain the functions of the mixer pump and tank operation. Flammable gas hazards associated with this transfer have been postulated and control implemented appropriately. Additionally, it is intended that the "post-transfer" condition of tank 241-SY-102 will not be maintained for an extended period, as this waste volume will need to be cross-sited to create additional tank 241-SY-102 volume for continuing saltwell pumping and further tank 241-SY-101 remediation activities.

The dilutions in tank 241-SY-101 are specified with an immediate goal of maintaining mixer pump operability and with a longer-term goal of releasing gas trapped in the waste and particularly the crust. Any other goals specified for tank back-dilutions can ultimately be expressed in these terms. These goals are accomplished by the addition of water to tank 241-SY-101 waste at specific locations by the use of different in-tank equipment. All this equipment is supplied by the dilution/flush water system. The choice of the tank back-dilution location is determined by the immediate goal. Protection of 
mixer pump operation indicates that water injection deep in the convective waste is optimal, whereas the release of gas from the crust is more efficiently served by addition of water in, on, or immediately beneath the crust.

Goals for the project: The interim goals of the project are to: 1) protect the mixer pump operability 2) begin releasing gas from the crust, and 3) begin dissolving the crust and solids in the slurry layer. The final goals of the project (Final State) are to solve both the level growth and BD-GRE safety issues in this tank by achieving a condition of the waste such that no active measures are required to safely store the waste, i.e., crust and non convective layer are mostly dissolved, and therefore the mixer pump will no longer be needed to prevent BD-GREs in excess of $100 \%$ LFL. Transfers (which are designed to create space in the tank) and dilution (which will dissolve the solids) will accomplish this. Dissolution of solids will result in a release of gas retained by those solids and remove that volume of solids as a future retention site.

In support of the interim project goals, the first tank back-dilution sequence is specified as up to a $72 \mathrm{kgal}$ water addition through the waste transfer pump (P-350) and up to 30 kgal through the transfer system vent line (via valve V-355).

This document was written with the best information available at the time. However, this information is subject to frequent change. For the most current information, see the project H-14 drawings, the Functional Requirements and Technical Criteria for the 241-SY-101 RAPID Mitigation System (HNF-3885), and the applicable Authorization Basis documents. 


\section{HNF-4264 REV. 2}

This page intentionally left blank. 


\subsection{PROCESS DESCRIPTION}

\subsection{WASTE CHARACTERISTICS}

The bulk physical behavior of the convective wastes from tank 241-SY-101 is of great concern to a transfer system. These wastes are saturated, high-salt materials with high specific gravity and high viscosity. These properties exist at the in-situ waste temperature of $120^{\circ} \mathrm{F}$. This transfer system poses the potential, upon a process upset, to allow the waste to be cooled to ambient (i.e., approximately atmospheric) temperatures. At these low temperatures, both the degree of waste saturation and viscosity rapidly increases, posing the scenario of essentially freezing solid in the transfer line. Driven by these concerns, both water dilution and temperature control are specified for the transfer of tank 241-SY-101 wastes.

As a result of these estimated behaviors, the volumetric dilution range specified for the waste transfer system varies from 2 parts waste to 1 part water to 1 part waste to 2 parts water. The average dilution is specified as 1 part waste to 1 part water. The low dilution limit is specified due to concerns about the build-up of high salt concentrations in tank 241-SY-102. Some of the 200 West area single-shell tank (SST) saltwell wastes possess high concentrations of phosphate. Interim stabilization activities accumulate these wastes in tank 241-SY-102. By limiting the nitrate/nitrite salt concentrations in tank 241-SY-102, the probability of phosphate precipitation will be minimized. The high dilution limit is specified from a desire to limit the impact of tank 241-SY-101 transfer activities on operational double-shell tank (DST) volume.

\subsubsection{Waste Solids Composition Dependence on Waste Dilution and Temperature}

The volume percent precipitated solids contained in the in-situ convective regions of tank $241-S Y-101$ are stated as $5 \%$ to $25 \%$ with an average of $15 \%$. This corresponds to the solids concentration at $120{ }^{\circ} \mathrm{F}$. During the actual transfer of waste from tank 241-SY-101 to tank $241-S Y-102$, the waste will be in the piping system for only a few seconds. It is prudent to assume that no dissolution of precipitated solids occurs during slurry transfer. Therefore, the solids concentrations in the transferred waste are diluted proportional to the dilution volume of water. Assuming that tank 241-SY-101 waste with 25 vol \% solids is diluted with water at the low dilution limit, the maximum expected solids concentration in the transfer line is approximately $17 \mathrm{vol} \%$ and the minimum somewhere around $2 \mathrm{vol} \%$. The average slurry solids concentration thus derived from tank 241-SY-101 convective waste and water dilution would be in the vicinity of $7.5 \mathrm{vol} \%$ with an expected range from about $2 \mathrm{vol} \%$ to $17 \mathrm{vol} \%$.

\section{Insoluble Solids}

The insoluble solids concentration of tank 241-SY-101 in the convective layer is estimated to be 3 weight percent or less. This is consistent with laboratory data and 
expert opinion. The concentration would be slightly lower on a volumetric basis because of the higher density of solids. The laboratory data (Steen 1999) indicate insoluble metals $(\mathrm{Ca}, \mathrm{Cr}, \mathrm{Fe}, \mathrm{Mn}, \mathrm{Ni}, \mathrm{Si}$, and $\mathrm{U}$ ) are present at around 0.5 weight percent. This corresponds to approximately 1 to 1.5 weight percent as metal oxides in the waste. The remainder of the solids is at least partially soluble, depending on temperature and concentration.

\section{Dissolution/Precipitation Kinetics}

The overall kinetics of dissolution will be measured in the dilution and mixing study (Estey 1999). The consensus of tank waste chemistry experts is that dissolution of the nitrate, nitrite, carbonate, and phosphate solids should be fairly rapid (minutes). This may not have much effect on transfer properties, as the transit time to tank 241-SY-102 will be less than one minute. Dissolution of oxalate is expected to take longer (hours).

Some precipitation of aluminum hydroxide is expected to occur because of the reduced $\mathrm{pH}$ of the diluted waste. This is known to be a slow process (days) and will not affect the pipeline behavior of the waste during the transfer. Although not expected to be a problem in the pipeline because of dilution, the precipitation of phosphates might occur within minutes and precipitation of oxalate and fluoro-phosphates within hours. The phosphate concentration in tank 241-SY-101 waste is fairly low at around 0.5 weight percent (Steen 1999). Precipitation of phosphates or fluoro-phosphate double salts may occur upon mixing with high phosphate saltwell liquors in tank 241-SY-102. However, this is neither a pumping nor a pipeline transfer issue.

The effect of the water dilution on solids dissolution has been studied using OLI Systems Inc. Environmental Simulation Program (ESP). The simulations indicate that dissolution of soluble salts is 87 percent complete at a dilution of 35 parts water to 100 parts waste and 98 percent complete at 50 parts water to 100 parts waste (Reynolds 1998). Further dilution actually results in a slight increase in solids because of $\mathrm{pH}$-induced precipitation of aluminum hydroxide.

These data support the preliminary conclusion that a dilution of 35 parts water to 100 parts waste is adequate, but ratios of at least 50 parts water to 100 parts waste are desired. The permitted dilution range is from 50 to 200 parts water to 100 parts waste. Experimental results using actual waste samples have confirmed these ratios (Person 1999).

The effect of dilution water temperature on solubility has also been modeled (Reynolds 1998). Increasing the temperature of the dilution water does not have as great an effect as increasing the dilution. At a dilution of 30 parts water to 100 parts waste, approximately $25 \%$ more soluble solids are present using $85^{\circ} \mathrm{F}$ dilution water than 130 ${ }^{\circ} \mathrm{F}$ water. The target temperature range for dilution water has been specified as $102{ }^{\circ} \mathrm{F}$ to $130^{\circ} \mathrm{F}$ to allow operational flexibility. Any dilutions using water in this temperature range will result in lower overall solids concentrations. 
A specific concern is the net effect of diluting tank 241-SY-101 waste with water at a nominal 1:1 ratio and allowing the mixture to equilibrate and cool to $65^{\circ} \mathrm{F}$ (which could happen in the discharge drop leg in tank 241-SY-102 if transfer line flushing were significantly delayed). Although not modeled, it is anticipated that the final solids concentration would be lower than the initial, just-mixed concentration. That is, dissolution with the diluent is expected to have a stronger effect than the reduction in temperature. A 1:1 dilution is about 3 times more dilution water than is necessary to dissolve all $\mathrm{NaNO}_{3}$ at the temperature of tank 241-SY-101 $\left(120^{\circ} \mathrm{F}\right)$. Even upon cooling to $65^{\circ} \mathrm{F}$, much more $\mathrm{NaNO}_{3}$ will be dissolved in the diluted waste than in the original tank 241-SY-101 waste.

\subsubsection{Waste Viscosity Dependence on Waste Dilution and Temperature}

Viscosity of slurries is highly complex and essentially indeterminate. The viscosity and viscosity behavior of many liquids, such as water, is well defined. However, when suspended solids are included in a liquid (i.e., a slurry), no universally known method exists to specify the viscosity of a slurry, even if other physical properties of the slurry are well known. For example, whereas most liquids can be considered Newtonian fluids, most slurries cannot. The only way the viscosity of actual slurry in a specific application can be positively determined is to measure it in that application. Such a measurement cannot be made in the application of the transfer from tank 241-SY-101.

The best known means of estimating a slurry viscosity from other known slurry parameters is via an "Einstein" type relationship. This relationship can at best be considered as only a rough rule-of-thumb. In its simplest form, this relationship expresses the slurry viscosity as a linear function of the carrier liquid viscosity and an exponential function of the solids loading or slurry density. Some terms are useful to define:

$$
\begin{aligned}
& \mathrm{c}=\text { carrier or liquid phase of a slurry } \\
& \mathrm{d}=\text { dispersed or solid phase of a slurry } \\
& \mathrm{m}=\text { bulk property of a slurry } \\
& \alpha=\text { phase volume fraction in a slurry (dimensionless) } \\
& \rho=\text { phase density of slurry (units of mass per volume) } \\
& \mu=\text { dynamic viscosity (units of mass per length per time) }
\end{aligned}
$$

The following relationships apply:

$$
\begin{aligned}
& \alpha_{c}+\alpha_{d}=1 \\
& \rho_{m}=\alpha_{c} \rho_{c}+\alpha_{d} \rho_{d} \\
& \rho_{\infty}=\rho_{m} \text { at infinite dilution, where } \rho_{m}=\rho_{c}
\end{aligned}
$$


$\alpha_{d}$ must be distinguished from the volume fraction of settled solids. Settled solids always contain void volumes occupied by the liquid phase so that the volume fraction of settled solids would be greater than the volume fraction of dispersed solids, or true solids.

The desired quantity is the effective, or slurry viscosity, $\mu_{m}$. A relationship can be defined as for Newtonian slurries:

$$
\mu_{\mathrm{m}}=\mu_{\mathrm{c}} \exp \left[\mathrm{k}\left(\rho_{\mathrm{m}}-\rho_{\infty}\right) / \rho_{\infty}\right] \quad \text { where "k" is an arbitrary constant }
$$

The term "Newtonian slurries" refers to slurries with slowly settling solids that possess an effective viscosity that can be measured in a viscometer. This form of an empirical expression for slurry viscosity is similar to other simplified models available in the literature (Shook and Rocco 1991). In their most simplified forms, these models state slurry viscosity as a function of the carrier liquid viscosity and the difference in density between the slurry and its carrier liquid.

To determine the constant in the relationship, the value of $\mu_{\mathrm{m}}$ must be known for at least one set of $\mu_{\mathrm{c}}, \rho_{\mathrm{c}}$, and $\rho_{\mathrm{m}}$ values. $\rho_{\mathrm{m}}$ is a value established fairly well for the waste in question. The range of $\rho_{\mathrm{m}}$ values for tank 241-SY-101 convective wastes at $120^{\circ} \mathrm{F}$ is stated as 1.45 to $1.75 \mathrm{gm} / \mathrm{cc}$ with a mean of $1.60 \mathrm{gm} / \mathrm{cc}$. For tank $241-\mathrm{SY}-101$ wastes, the value of $\rho_{\mathrm{c}}$ at any non-infinite dilution is not known with much precision. The only thing that can be positively stated for tank $241-S Y-101$ waste is that at infinite dilution, $\rho_{\mathrm{m}}=\rho_{\mathrm{c}}=1.0 \mathrm{gm} / \mathrm{cc}$.

Tingey et al. (1994) and Stewart (1996) document viscosity analyses performed on tank $241-S Y-101$ wastes. The former investigated material from core 22 taken during Window $\mathrm{C}$ while the latter reported results from ball rheometer testing in tank 241-SY-101. Both references report Non-Newtonian, shear-thinning (thixotropic) behavior of the tank wastes.

Analyses documented in Tingey et al. (1994) looked at parameters of $\rho_{\mathrm{m}}$, settled solids density, settled solids volume fraction, filtered solids weight fraction, and viscosity at a $400 \mathrm{sec}^{-1}$ shear rate at a $0,20,40,70$, and $100 \mathrm{vol} \% 2 \mathrm{M} \mathrm{NaOH}$ dilution and 50,70 , and $90{ }^{\circ} \mathrm{C}$. The results indicate that little difference could be noted between $\rho_{\mathrm{m}}$ and the settled solids density at any dilution or temperature. Differences in viscosity, volume percent settled solids, and weight percent filtered solids showed much more variation at differing dilutions and temperatures. In this application, $2 \underline{\mathrm{M} \mathrm{NaOH}}$ can be considered equivalent to water

Tingey et al. (1994) reported a dynamic viscosity of $40 \mathrm{cP}$ at a $400 \mathrm{sec}^{-1}$ shear rate for undiluted waste at $50^{\circ} \mathrm{C}$. Stewart (1996) reported ball rheometer viscosity behavior with an uncertainty factor of two, shown in Table 2-1. 
Table 2-1. In-Situ Tank 241-SY-101 Apparent Viscosity

\begin{tabular}{|c|c|c|c|c|}
\hline Shear rate (sec') & 1 & 10 & 100 & 400 \\
\hline Viscosity (cP) & $\sim 600$ & $\sim 150$ & $\sim 80$ & $\sim 40$ \\
\hline
\end{tabular}

The viscosity results from both references for undiluted wastes at tank temperature and a $400 \mathrm{sec}^{-1}$ shear rate show good agreement. When shear rate is expressed as the pipe flow velocity divided by the pipe inner radius, a $6 \mathrm{ft} / \mathrm{sec}$ flow velocity corresponds to a shear rate of about $50 \mathrm{sec}^{-1}$.in a 3-inch ID pipe. At this shear rate, Stewart (1996) indicates an in situ waste viscosity of about $100 \mathrm{cP}$.

A summary of selected data for tank $241-\mathrm{SY}-101$ waste at $50{ }^{\circ} \mathrm{C}$ at various water dilutions from Tingey et al. (1994) is shown in Table 2-2.

Table 2-2. In-Situ Tank 241-SY-101 Physical Properties

\begin{tabular}{|c|c|c|c|c|c|}
\hline $\begin{array}{l}\text { Dilution } \\
\text { (water/waste) } \\
\text { Property }\end{array}$ & $0: 1$ & $0.2: 1$ & $0.4: 1$ & $0.7: 1$ & $1: 1$ \\
\hline $\begin{array}{l}\text { Apporent } \\
\text { Viscosity at } 400 \\
\text { sec (cP) }^{\prime} \text { (cP) }\end{array}$ & 39.4 & 35.8 & 12.3 & 6.8 & 2.9 \\
\hline $\begin{array}{l}\text { Vol } \% \text { settled } \\
\text { solids }\end{array}$ & 100 & 100 & 96 & 89 & 34 \\
\hline $\begin{array}{l}\text { Wt \% filtered } \\
\text { solids }\end{array}$ & 83 & 60 & 68 & 40 & 25 \\
\hline $\begin{array}{l}\text { Settled solids } \\
\text { density }\end{array}$ & 1.72 & 1.68 & 1.59 & 1.51 & 1.42 \\
\hline Slurry density & 1.72 & 1.68 & 1.60 & 1.48 & 1.34 \\
\hline
\end{tabular}

The value of 1:1 $100 \mathrm{vol} \%$ dilution corresponds to the minimum dilution specified for the waste transfer system. Based on the shear viscosity behavior reported by Tingey et al. (1994), the viscosity at $50 \mathrm{sec}^{-1}$ shear rate would appear to be 2.4 times larger than the value at $400 \mathrm{sec}^{-1}$. The viscosity of water at $50^{\circ} \mathrm{C}$ is $0.55 \mathrm{cP}$.

For a $50 \mathrm{sec}^{-1}$ shear rate, tank 241-SY-101 waste viscosities can be derived from data in Tingey et al. (1994) and Stewart (1996). These are shown in Table 2-3: 
HNF-4264 REV. 2

Table 2-3. In-Situ Tank 241-SY-101 Apparent Viscosity

\begin{tabular}{|l|c|c|c|c|c|}
\hline $\begin{array}{l}\text { Dilution ? } \\
\begin{array}{c}\text { (rater/waste) } \\
\text { Property }\end{array}\end{array}$ & $0: 1.0$ & $0.2: 1.0$ & $0.4: 1$ & $0.7: 1$ & $1: 1$ \\
\hline $\begin{array}{l}\text { Apparent } \\
\text { Viscosity at 50 } \\
\text { sec }^{-1} \text { (c) }\end{array}$ & 100 & 85 & 30 & 16 & 7.0 \\
\hline
\end{tabular}

This suggests a slurry viscosity expression in the form of:

$$
\begin{aligned}
& \mu_{\mathrm{m}}=0.55 \mathrm{cP} \exp \left[\mathrm{k}\left(\rho_{\mathrm{m}}-1.0 \mathrm{gm} / \mathrm{cc}\right) / 1.0 \mathrm{gm} / \mathrm{cc}\right] \\
& \text { where } 100 \mathrm{cP}=0.55 \mathrm{cP} \exp [\mathrm{k}(1.6 \mathrm{gm} / \mathrm{cc}-1.0 \mathrm{gm} / \mathrm{cc}) / 1.0 \mathrm{gm} / \mathrm{cc}] \\
& \text { since } \mu_{\mathrm{m}}=100 \mathrm{cP} \text { when } \rho_{\mathrm{m}}=1.6 \mathrm{gm} / \mathrm{cc} . \text { This yields } \mathrm{k}=8.67
\end{aligned}
$$

Therefore, at $50^{\circ} \mathrm{C},\left(\sim 120^{\circ} \mathrm{F}\right)$ and a shear rate of $50 \mathrm{sec}^{-1}$, the expression for the slurry viscosity produced by the waste transfer system becomes:

$$
\mu_{\mathrm{m}}=0.55 \mathrm{cP} \exp \left[8.67\left(\rho_{\mathrm{m}}-1.0 \mathrm{gm} / \mathrm{cc}\right) / 1.0 \mathrm{gm} / \mathrm{cc}\right]
$$

This expression yields the results shown in Table 2-4.

Table 2-4. Slurry Viscosity Behavior at $120^{\circ} \mathrm{F}$ and $50 \mathrm{sec}^{-1}$ Shear Rate

\begin{tabular}{|c|c|c|}
\hline $\begin{array}{c}\text { Slurry Density (gm/cc) } \\
\text { (corresponding to no dilution) }\end{array}$ & Mean Viscosity (cP) & Maximum Viscosity (cP) \\
\hline $\begin{array}{c}1.4 \\
\text { (corresponding to minimum specified } \\
\text { dilution of 1 part water to 2 parts waste) }\end{array}$ & 100 & 200 \\
\hline $\begin{array}{c}1.3 \\
\text { (corresponding to mean dilution of 1 part } \\
\text { water to 1 part waste) }\end{array}$ & 18 & 36 \\
\hline $\begin{array}{c}1.2 \\
\text { 1.0 }\end{array}$ & 7.4 & 15 \\
\hline $\begin{array}{c}\text { (corresponding to maximum dilution of } 2 \\
\text { parts water to } 1 \text { part waste) }\end{array}$ & 3.1 .0 & 6.2 \\
\hline
\end{tabular}


From the above table, at the specified waste transfer system operating temperature of $120^{\circ} \mathrm{F}$, the minimum specified dilution of 1 part by volume water to 2 parts by volume waste yields a slurry with an estimated viscosity of less than $30 \mathrm{cP}$. Only in the extreme of low dilution at the high viscosity bound does it exceed $30 \mathrm{cP}$. At the mean 1:1 dilution, the expected slurry viscosity is about $7.5 \mathrm{cP}$ with an expected maximum of $15 \mathrm{cP}$.

\subsubsection{Waste Critical Velocity Dependence on Waste Dilution and Temperature}

Critical velocity in slurry flow is an estimated fluid flow velocity at which the effects of random, turbulent fluid motions provide enough agitation to keep individual solid particles in the slurry suspended in the slurry. The idea is that if the velocity of slurry transport is kept above the critical velocity, that solids deposition and the attendant potential of line plugging can be avoided. The concept of a critical velocity is generally acknowledged as having no hard scientific definition, but rather results from experimental data fits as determined from various researchers.

A review of many critical velocity correlations as applied to Hanford tank wastes has been performed (Estey and Hu 1998). Specific application of the concept to the tank 241-SY-101 transfer has also been performed by Pacific Northwest National Laboratory (PNNL) (Onishi and Recknagle 1999). Both analysis surveys indicate that a specified slurry flow velocity of $6 \mathrm{ft} / \mathrm{sec}$ meet all practical requirements for critical velocity, provided some amount of water dilution of the waste is performed.

The specific analyses documented by PNNL indicate that there are values of water dilution and slurry temperature that optimize (i.e., minimize) the resultant critical velocity. The concept behind this finding is that high carrier liquid viscosities are more efficient at momentum transfer to solid particles, yet impose higher pressure drops in piping and require larger velocities to achieve turbulent flow. In contrast, low carrier liquid viscosities make possible turbulent flow at lower velocities, yet are less efficient ant transferring momentum to the solid particles in a slurry

Both increasing water dilution and, to a lesser extent, increasing slurry temperature, lower the carrier liquid viscosity in a slurry. At higher values of changes in water dilutions and temperatures, the affect on critical velocity is small. However, very evident in the PNNL findings is that undiluted tank 241-SY-101 wastes posses a significant carrier liquid viscosity. The net effect is to require extremely high flow velocities to achieve turbulent flow in the transport of undiluted wastes. This result is strong evidence for the need of at least some water dilution of tank 241-SY-101 wastes.

\subsubsection{Waste Compatibility with Tank 241-SY-102 Wastes}

The tank 24l-SY-101 level-rise remediation project acknowledges the need to perform a waste transfer compatibility assessment (Fowler 1995; Mulkey 1997) for this transfer. 
This is a requirement specified by Administrative Control AC 5.12 (LMHC 1999c). The assessment must be successfully completed in order for the $150-\mathrm{kgal}$ waste transfer to occur.

The waste transfer compatibility assessment acts as a screening tool that determines if any safety or operationally related concerns might arise as a result of the proposed transfer. Upon Process Engineering request, or upon any positive findings for the waste compatibility criteria, a more in-depth analysis must be performed before a disposition is determined. The findings of the in-depth analysis of the Complexed Waste compatibility criteria has been reported (Beck 1999) with favorable results. At this time, no additional waste incompatibilities are expected from this assessment.

Table 2-5 shows the preliminary chemical compound distribution based on fiscal year (FY) 1999 core sample of tank 241-SY-101.

Table 2-5. Preliminary FY 1999 Core Sample Characterization

\begin{tabular}{|c|c|c|}
\hline Chemical Species & $\begin{array}{c}\text { Mass Percentage of Waste } \\
\text { Reported to Two Sigmificant Figures }\end{array}$ & $\begin{array}{c}\text { Mass Percentage of Waste } \\
\text { Normalized to Two Significant } \\
\text { Figures }\end{array}$ \\
\hline $\mathrm{H}_{2} \mathrm{O}$ & 40 & 39 \\
\hline $\mathrm{Na}$ & 19 & 18 \\
\hline $\mathrm{Al}(\mathrm{OH})_{4}$ & 12 & 12 \\
\hline $\mathrm{NO}_{3}$ & 11 & 11 \\
\hline $\mathrm{NO}_{2}$ & 11 & 11 \\
\hline $\mathrm{OH}_{\mathrm{CO}}$ & 2.8 & 2.7 \\
\hline $\mathrm{C}_{2} \mathrm{O}_{4}$ & 2.2 & 2.1 \\
\hline $\mathrm{Cl}$ & 1.3 & 1.3 \\
\hline $\mathrm{CHO}_{2}$ & 0.85 & 0.82 \\
\hline $\mathrm{SiO}_{2}$ & 0.75 & 0.72 \\
\hline $\mathrm{PO}_{4}$ & 0.64 & 0.62 \\
\hline $\mathrm{Cr}_{2} \mathrm{O}_{3}$ & 0.55 & 0.53 \\
\hline $\mathrm{SO}_{4}$ & 0.50 & 0.48 \\
\hline $\mathrm{K}_{2}$ & 0.35 & 0.34 \\
\hline $\mathrm{C}_{2} \mathrm{H}_{3} \mathrm{O}_{2}$ & 0.35 & 0.34 \\
\hline & 0.18 & 0.17 \\
\hline
\end{tabular}

\subsubsection{Other Waste Property Issues}

Concern has been expressed about the formation of hydrates (hydrogen rich compounds) in tank 241-SY-101 and their contribution to the total inventory of hydrogen in the tank. Hydrates are not considered in estimating the retained gas volume in the tank. Hydrates generally are not reactive (prone to releasing hydrogen) and, therefore, are no more of a source of hydrogen than water itself. In any event, tank safety is premised upon the control of the hydrogen concentration in the dome space. Gaseous hydrates require low temperatures and high pressures in order to form. The TAP has concluded that temperatures and pressures in Tank 241-SY-101 preclude the formation of gaseous 
hydrates in this tank and, therefore, gaseous hydrates are not a safety issue for this project.

\subsection{SPECIFIC WASTE PROPERTY ISSUES FOR REMEDIATION ACTIVITIES}

Table 2-6 shows current relevant tank waste parameters for tank back-dilution:

Table 2-6. Parameters of Concern for Tank 241-SY-101 Level Growth

\begin{tabular}{|c|c|}
\hline Tank Parameter & Value \\
\hline Gas generation rate & $700 \pm 140 \mathrm{ft}^{3} /$ week \\
\hline Significant Tank Levels & \\
\hline Recent high crust level & $\begin{array}{l}434.5 \text { inches } \\
\text { (on } 5 / 24 / 99 \text { ) }\end{array}$ \\
\hline $\begin{array}{l}\text { Approximate level of bottom } \\
\text { of crust (bubble slurry layer) }\end{array}$ & 310 inches \\
\hline Mixer pump suction & 235 inches \\
\hline Transfer pump suction & 96 inches \\
\hline Mixer pump burrowing ring & 9 inches \\
\hline Gas release rate & $\begin{array}{c}\text { Variable: } \\
\left(700 \mathrm{ft}^{3} / \text { week } \leq \text { gas release rate } \geq 700\right. \\
\left.\mathrm{ft}^{3} / \text { week }\right)\end{array}$ \\
\hline $\begin{array}{c}\text { Typical Baseline } \\
\text { Steady-State Gas Release } \\
\text { Concentrations }\end{array}$ & 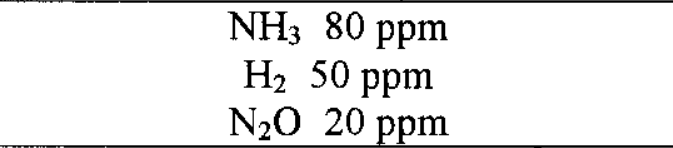 \\
\hline $\begin{array}{l}\text { Estimated volume of } \\
\text { retained gas }\end{array}$ & approximately $12,000 \mathrm{ft}^{3}$ \\
\hline Historical crust growth rate & 0.08 inches/day \\
\hline $\begin{array}{l}\text { Current crust growth rate } \\
\text { (since April 1, 1999) }\end{array}$ & approximately 0 inches/day \\
\hline $\begin{array}{l}\text { Estimated crust } \\
\text { shear-strengths through the } \\
\text { vertical profile }\end{array}$ & $\begin{array}{l}\text { Top (freeboard) layer: } \sim 20 \mathrm{k} \text { to } 50 \mathrm{kPa} \\
\text { Middle (paste) layer: } \sim 3 \mathrm{k} \text { to } 10 \mathrm{k} \mathrm{Pa} \\
\text { Bottom (bubble slurry) layer: } \sim 400 \mathrm{~Pa} \\
\text { Bulk crust: } \sim 1.6 \text { to } 3.0 \mathrm{kPa}\end{array}$ \\
\hline $\begin{array}{c}\text { Estimated date when double } \\
\text { shell height }\left(458^{\prime \prime}\right) \text { will be } \\
\text { exceeded }\end{array}$ & $\begin{array}{l}\text { - November } 1999 \text { (planning basis) } \\
\text { - March } 2000 \text { (historical trend of } 0.08 \\
\text { in./day) } \\
\text { - No projection for current crust growth } \\
\text { rate }\end{array}$ \\
\hline
\end{tabular}


The general findings of various tank back-dilution analyses has revealed unintuitive results. From consideration of sinking the crust, the findings favor adding as much of the allowable dilution water volume as possible to the top of the crust. A transfer out of tank $241-S Y-101$ of $150 \mathrm{kgal}$ and hypothetical back dilutions of $100 \mathrm{kgal}$ at the transfer pump and $50 \mathrm{kgal}$ on top of the crust show that:

- Dissolution of the freeboard (20 inches) and 6 inches into the upper paste layer below occurs, but the bubble slurry layer is unaffected.

- The resulting crust will float with plenty of margin, even considering imperfect mixing for the entire layer.

A $35 \mathrm{kgal}$ water addition on top of the crust and $125 \mathrm{kgal}$ through the transfer pump starts getting close to the point where the crust bulk density becomes higher than the density of the fluid in which it floats. It is anticipated that $30 \mathrm{kgal}$ top $/ 120 \mathrm{kgal}$ deep dilution will sink the crust. But $75 \mathrm{kgal}$ on top and $75 \mathrm{kgal}$ below works well in thinning the crust without getting too close the bubble slurry. It thins the upper part of the crust to get ready for purposeful sinking the next transfer/back dilution.

Additionally, no temperature controls were deemed necessary for any tank back-dilution water applied directly to the upper surface of the crust.

It is recognized that the $A B$ controls for the dilution activities may not be fully developed at the time of the initial tank back-dilution. As such, it is not necessary to commence tank back-dilution activities immediately following the initial waste transfer. Various analyses were performed to determine the optimal tank back-dilution sequence:

\section{Mixer Pump Survivability/Operability Versus Crust Encroachment:}

Analysis of the mixer pump to determine if a crust level control is needed (Meyer, et al. 1999) showed that the ingestion of a moderate amount of either solids, gases, or air should not damage the pump unless unusual and unexpected conditions are encountered. The amount of these materials that could be drawn into the pump through the small volute gap at a 262 inch elevation is inconsequential and the effective suction elevation of the pump is at 235 inches. Additionally, the suction vortex associated with submerged suction pumps essentially renders the separation specified by the previous 12 inch control margin as ineffective. As such, the recommended criterion is to monitor the mixer pump discharge pressure and cease operation if this pressure falls below a certain value.

The concept will be, after initial waste transfer, to review the mixer pump operating parameters following each pump run for evidence of mixer pump performance degradation. This review after each pump run will continue until the TRG determines that changed tank conditions have not significantly degraded the capability of the mixer pump to perform its intended function. (hopefully, a few runs after the back dilution should be adequate to address this). In addition, the normal quarterly review of mixer pump performance would continue. 


\section{Crust Vertical Location versus Water Addition:}

This analysis investigated the effects of adding dilution water on / in / just below crust to predict what happens; and to predict the rate of gas release as function of water addition rate, water addition location, and time. This analysis has shown that the crust in tank 241-SY-101 is composed of three regions of differing properties through a vertical profile. The lowest crust layer is commonly called the "bubble slurry" which is composed of significant void volume and has the lowest density. The next layer, the so-called "paste layer" has more mechanical strength but less void volume than the bubble slurry. Nevertheless, the paste layer comprises the largest total solids and void volumes within the crust. The upper layer is commonly called the "freeboard" as it extends above the liquid level and has drained of its liquid content. Although it possess voids, these are filled with air. Being composed of dried salts, it possesses the highest density within the crust profile.

It is estimated that the entire crust has a bulk density of $1.41 \mathrm{gm} / \mathrm{cc}$, a bulk yield strength on the range of $1.6 \mathrm{kPa}$ to $3.0 \mathrm{kPa}$, and contains $7200 \mathrm{SCF}$ of gas. The majority of the gas volume ( $5200 \mathrm{SCF}$ ) resides in the paste layer. In various dilution scenarios, a major concern is the sinking of the crust. This would occur if the bulk density of the crust became greater than the density of the saturated salt solution in which it floats. It was found that the most efficient way to provide margin against this happening is to remove the freeboard layer by direct addition of dilution water on top of the crust. This action dissolves the solid salts forming the freeboard (and thus the crust deadweight), significantly lowering the effective bulk density of the crust. Protecting the low-density bubble slurry layer against water dilution and resultant gas bubble release also works to maintain a lower bulk crust density.

Gas releases from the crust due to dissolution of solids matrices forming the void volumes was deemed to be a controllable phenomena bounded by established safety controls.

\section{Crust-Equipment Structural Analysis:}

This was specified to determine the force term development and perform failure analysis on the tank structure and equipment. The upcoming transfer from and tank back-dilution to Tank 241-SY-101 have raised concerns about the potential for damage as the crust rises and falls with changing liquid level. The project analyzed how much of the crust mass ( 1500 metric tons) might remain attached to the tank wall or suspended hardware (multifunction instrument trees, velocity density temperature trees, and mixer pump) as the liquid is removed and what motions might result if the attached sections of the crust were to break away and fall. 
The observed and measured behavior of the crust indicates that it will follow the liquid level through transfer and dilution. The properties and dimensions of the crust layer make it impossible for any large section of it to attach to the tank wall or to bridge between available supports, such as in-tank equipment. Analysis has shown that the crust does not have enough mechanical strength to cause localized stress concentration damage to in-tank equipment due to the vertical displacements associated with the waste transfers and dilutions in tank 241-SY-101. Contrary to this evidence, even if it is assumed that the largest possible block of crust is attached and then falls, there is no obvious mechanism to cause damage to equipment. Even if the bulk crust were to sink as a coherent mass, which is deemed highly unlikely, the stresses imparted by this event would not damage the tank structure or equipment contained therein. More likely the crust would sink as much smaller solid masses, perhaps as small as individual granules of precipitated salts in the micron size range, as dissolution releases bound gas bubbles or dissolves the binding salt species.

The design of the in-tank equipment is able to withstand much larger loads than are possible given the current configuration of the crust. In any event, in-tank monitoring of the crust condition will permit the transfer to be stopped if significant crust attachment or distortion occurs.

\section{If Crust Sinks, What is Impact to Mixer Pump Performance:}

Analysis has shown that the mixer pump can impart a shear force of $1600 \mathrm{~Pa}$ at a radial distance of $20 \mathrm{ft}$ from the discharge nozzle. This force would not, however, be enough to disrupt the majority of the solid mass of crust if it retained the same mechanical properties it is estimated to possess at present. Therefore, disruption of such a mass would be dependent upon dissolution of the solids matrices, which would eventually occur upon crust sinking. However, as referred to above, the most likely mechanism for crust sinking would occur as small granules of precipitate salts once the gas bubbles or binding structure composed of the more soluble precipitated salts are dissolved by the dilution water.

\section{Identify if a Control Needs to be Developed for the Water Addition Rate during Tank} Back-Dilution:

Preliminary analysis indicates that constraining the addition of dilution water to the convective layer by a volume of $150 \mathrm{kgal}$ and an addition rate of $<125 \mathrm{gpm}$ will prevent the headspace of tank $241-\mathrm{SY}-101$ from exceeding $25 \%$ of LFL.

\section{(FY2000) Define Criteria for USQ Closure / End State Analysis:}

This criteria has been informally defined as a minimum goal of altering the properties of the waste to eliminate the need for mixer pump operation to demonstrate safety of tank 241-SY-101. A more ambitious goal will be to alter 
the waste properties sufficiently to remove the tank from the Flammable Gas Watchlist. The ultimate goal will be to transfer enough waste out of the tank to restore it as an operational DST.

Conclusion: The project continues to evaluate parameters that are critical to determining the optimum volume and method of application of the tank back-dilution for Tank 241-SY-101. No new (beyond those already identified with the transfer) or major hazards have been identified to be associated with dilution of the top of the crust in tank 241-SY-101 (via valve V-355) and with dilution of the mixed slurry layer via various flow paths through the transfer pump (pump P-350). It is now considered safe to initiate dilution within days after the initial transfer. The remediation project intends to complete all transfer and tank back-dilution steps early in Fiscal Year 2000. 


\section{HNF-4264 REV. 2}

This page intentionally left blank. 


\subsection{EQUIPMENT DESCRIPTIONS}

This section provides an overview of the primary piping and instrumentation systems associated with the Respond and Pump in Days (RAPID) transfer system. The current list of transfer system H-14 drawings is shown in Figure 3.1: 


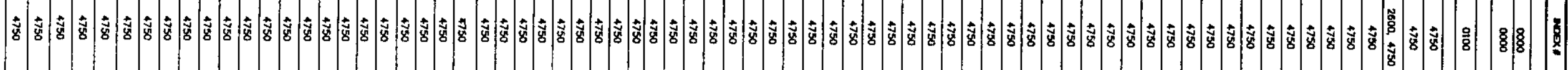

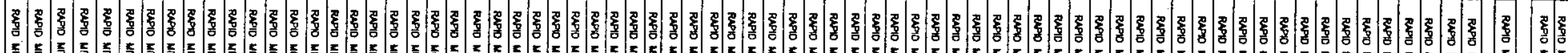

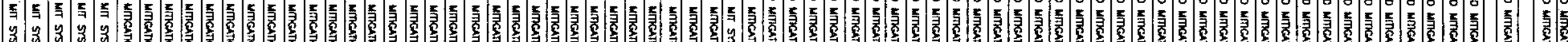

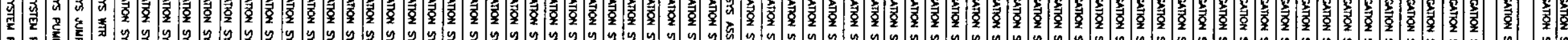

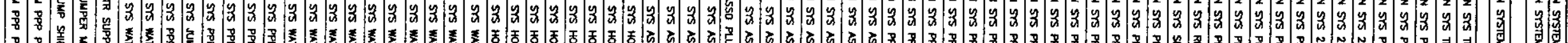

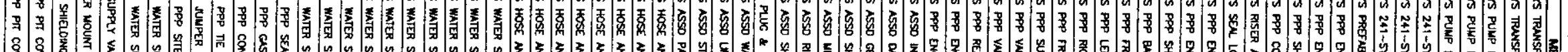

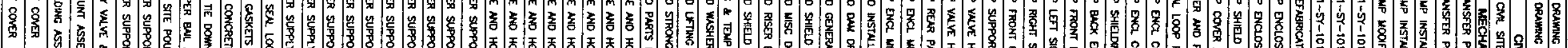

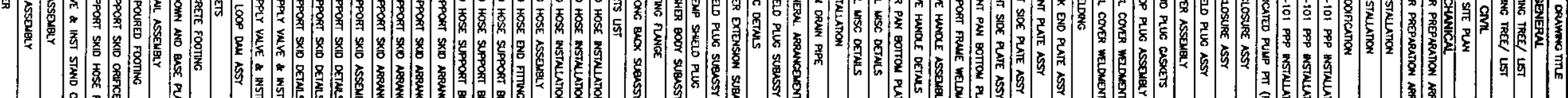

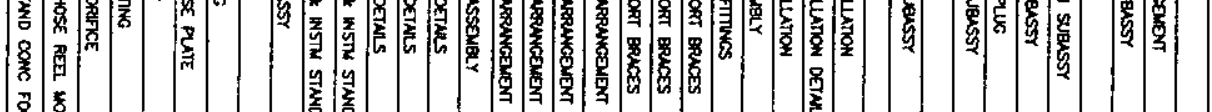
票 受部

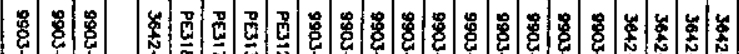

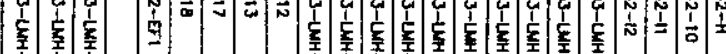

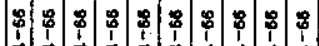

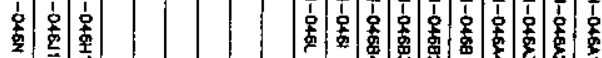

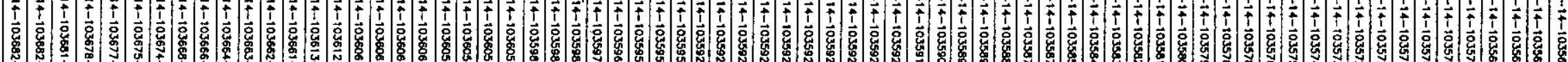

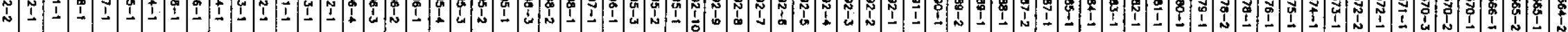

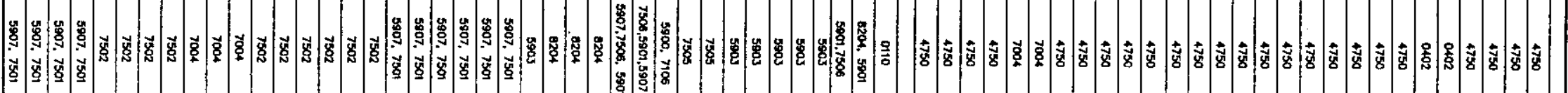

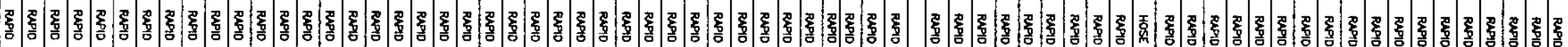
(5)

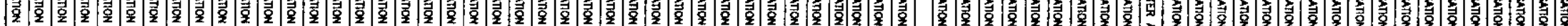

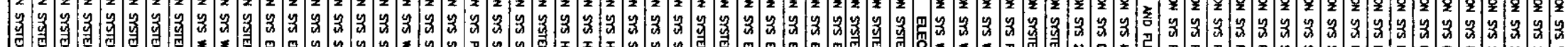

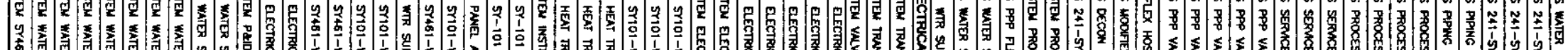

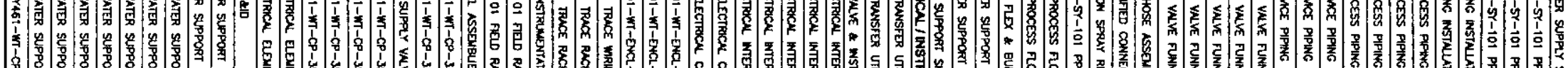

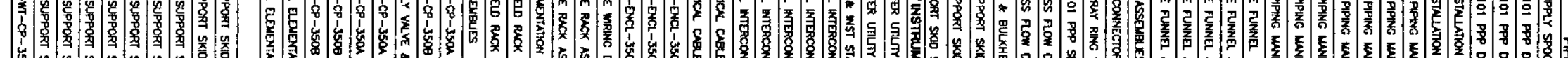

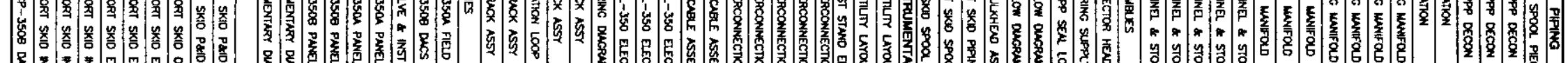

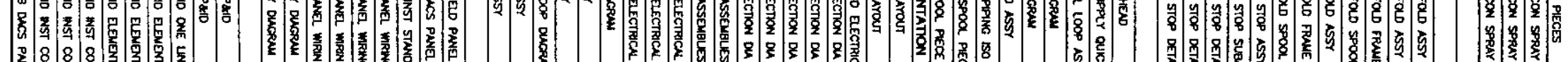

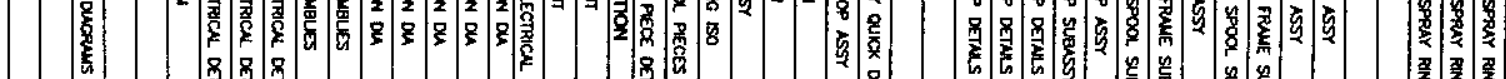

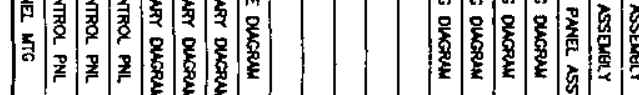

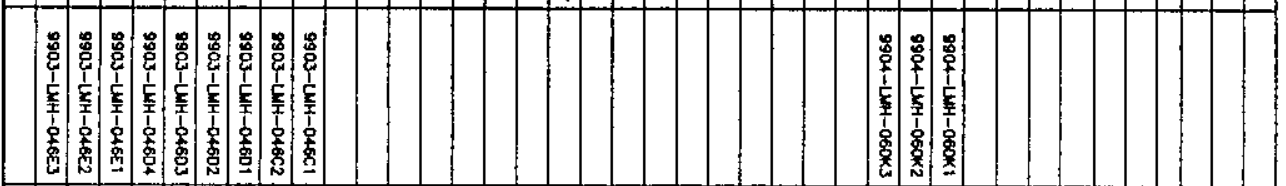

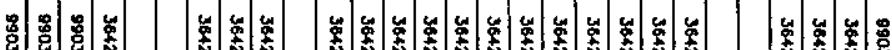

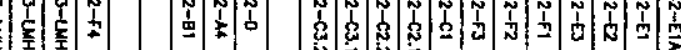

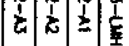

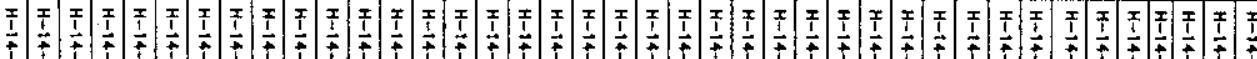

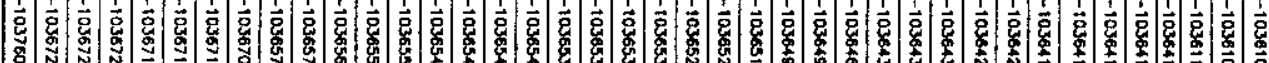

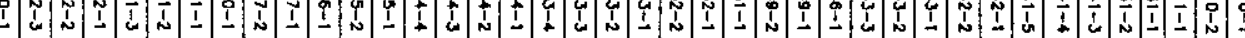

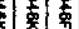

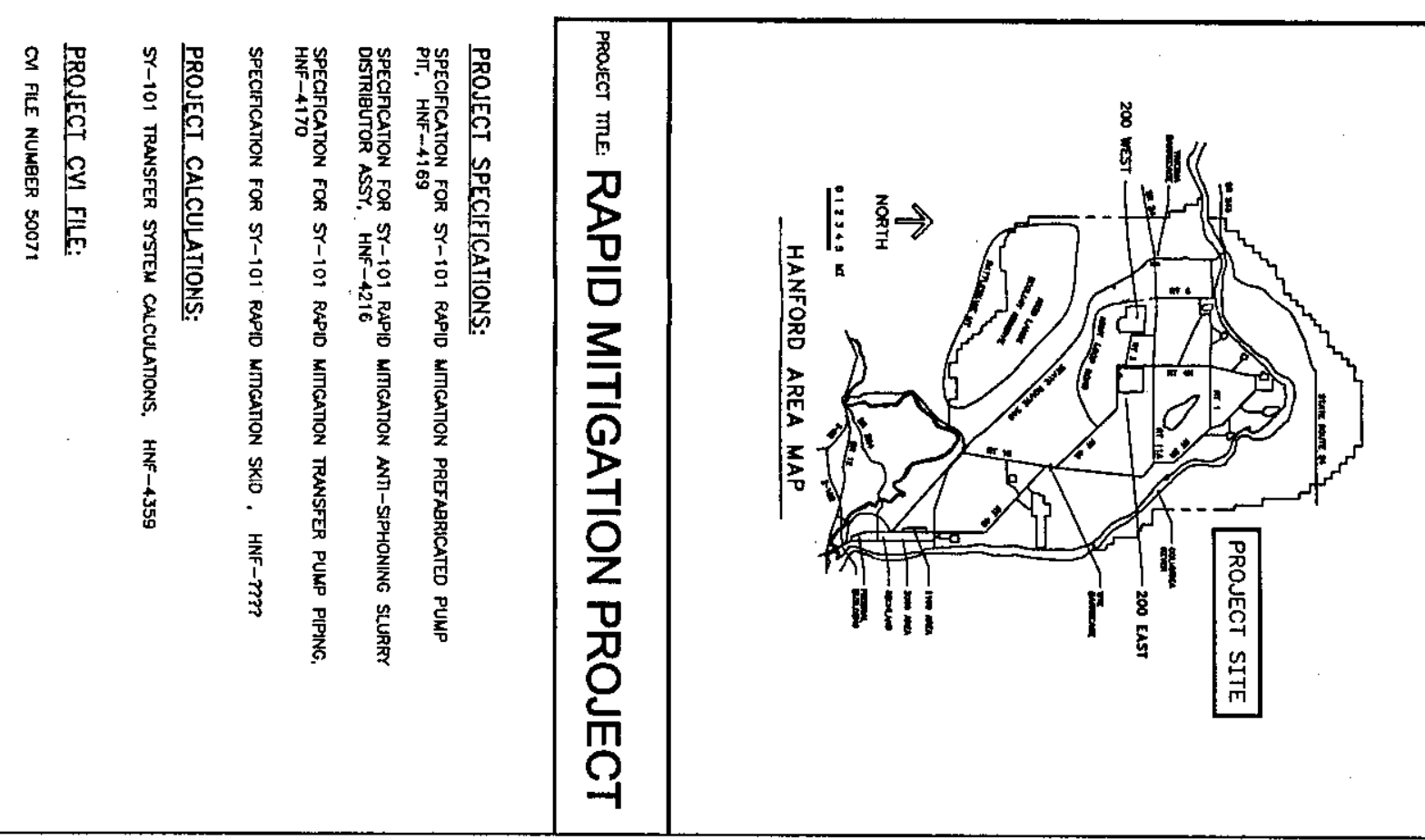




\subsection{WATER SUPPORT SKID}

A dedicated water supply for dilution and flushing is provided with the transfer system. The major features are two 20-HP water supply pumps, a 2,000-gal supply tank, and a 75 -gal nitrogen pressurized flush accumulation tank mounted on an $8 \times 20 \mathrm{ft}$ skid. The total weight of the Water Support Skid is approximately 11,000 lbs. ACC-401 supplies the capability to flush the transfer line in the event of loss of electrical power. This flush is driven by pressure from the nitrogen bottle. The bottle is normally pressurized to a nominal 2,000 psi, but is regulated to 100 psi. Figure 3-2 shows a schematic of the Water Support Skid. The 2,000-gal supply tank incorporates an air-gap between the site raw water supply and the transfer system water supply. This provides the site raw water system with a degree of protection from radioactive contamination.

\section{Figure 3-2. Water Support Skid}

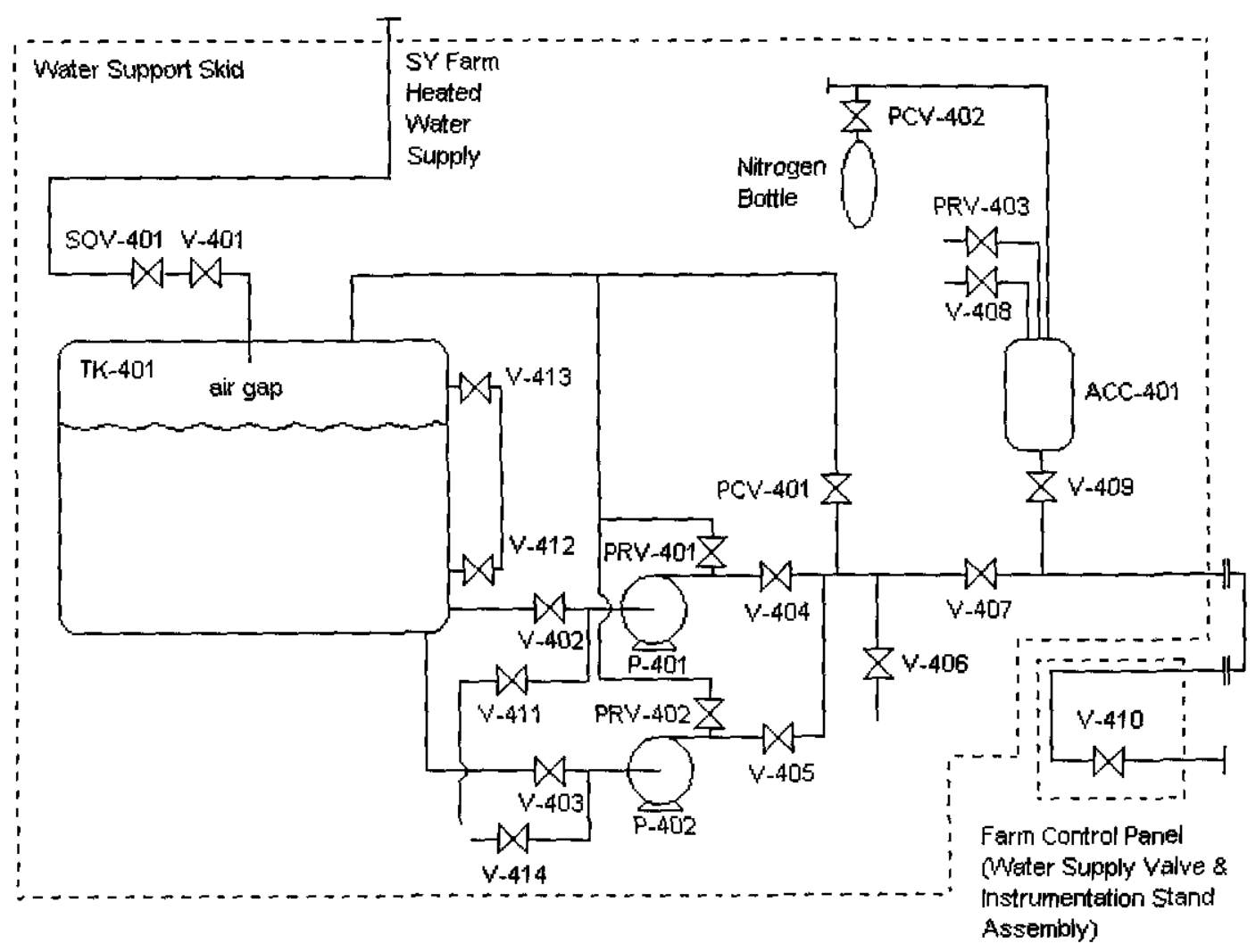

Key:

$\mathrm{ACC}=$ accumulator

$P=$ pump

$P C V=$ pressure control valve

$P R V=$ pressure-regulating valve

$\mathrm{SOV}=$ solenoid-operated valve

$\mathrm{TK}=$ tank

$\mathrm{V}=\quad$ valve 
HNF-4264 REV. 2

The Water Support Skid (WSS) contains the process routing valves listed in Table 3-1

Table 3-1. Water Support Skid Valve Functions

\begin{tabular}{|l|l|}
\hline \multicolumn{1}{|c|}{ Valve EN } & \multicolumn{1}{|c}{ Descriotion of Valve Function } \\
\hline POR32-RW-SOV-401 & Raw Water Supply to Skid Solenoid Operated Isolation \\
\hline POR32-RW-PCV-401 & Raw Water Outlet Line Pressure Control Valve \\
\hline POR32-RW-PCV-402 & Accumulator Pressure Control Valve \\
\hline POR32-RW-PRV-401 & P-401 Outlet Line Pressure Relief Valve \\
\hline POR32-RW-PRV-402 & P-402 Outlet Line Pressure Relief Valve \\
\hline POR32-RW-PRV-403 & Accumulator ACC-401 Pressure Relief Valve \\
\hline POR32-RW-V-401 & Raw Water Supply to Skid Isolation Valve \\
\hline POR32-RW-V-402 & Pump P-401 Inlet Isolation Valve \\
\hline POR32-RW-V-403 & Pump P-402 Inlet Isolation Valve \\
\hline POR32-RW-V-404 & Pump P-401 Outlet Isolation Valve \\
\hline POR32-RW-V-405 & Pump P-402 Outlet Isolation Valve \\
\hline POR32-RW-V-406 & Fush Drain Isolation Valve \\
\hline POR32-RW-V-407 & Outlet Line Isolation Valve \\
\hline POR32-RW-V-408 & Accumulator ACC-401 Vent Isolation Valve \\
\hline POR32-RW-V-409 & Accumulator ACC-401 Isolation Valve \\
\hline POR32-RW-V-410 & Valve Stand Raw Water Line Isolation Valve \\
\hline POR32-RW-V-411 & Pump Inlet Line Drain Isolation Valve \\
\hline POR32-RW-V-412 & Tank TK-401 Sight-Glass Lower Isolation Valve \\
\hline POR32-RW-V-413 & Isolation Valve \\
\hline POR32-RW-V-414 & WSS: Pump Inlet Line Drain Isolation Valve \\
\hline
\end{tabular}

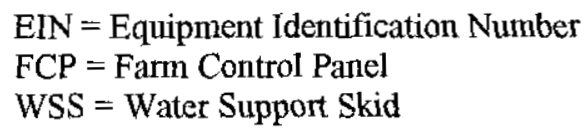

During steady-state dilution flow operation the water skid is capable of providing water at $102{ }^{\circ} \mathrm{F}$ to $130^{\circ} \mathrm{F}$ The $130^{\circ} \mathrm{F}$ limit is specified to comply with Authorization Basis temperature controls in tank 241-SY-101, whereas the $102^{\circ} \mathrm{F}$ limit is specified to avoid problems attendant to potential precipitation of saturated salts. The dilution water flow rates in steady-state operation are specified as 20 to $70 \mathrm{gpm}$. The $20 \mathrm{gpm}$ limit is specified to avoid problems attendant to potential precipitation of saturated salts, whereas the $70 \mathrm{gpm}$ limit is specified by heating capabilities of the water supply equipment. Upon a loss of electric power, ACC-401 provides the means to clear the process lines of waste slurry. 


\subsection{TANK 241-SY-101 PREFABRICATED PUMP PIT (PPP) AND NEW GENERATION TRANSPER PUMP (NGTP, P-350)}

The Prefabricated Pump Pit (PPP) at tank 241-SY-101 contains waste and water supply piping and routing valves for the transfer system, various instrumentation, and the mounting for the P-350 pump. The PPP also provides for a drain, seal loop, and manually operated system high-point vent, which return to tank 241-SY-101. The PPP drain is capable of a flow rate of $20 \mathrm{gpm}$.

The P-350 pump extends through the PPP base plate into the tank 241-SY-101 waste. The pump would have the most versatility if the inlet were placed as low in the tank as possible. However, concerns about the physical properties of settled solids in this tank and uncertainties about corresponding waste viscosities has dictated placing the pump inlet well above the settled solids layer in the well mixed convective regions of the waste at an elevation of approximately $8 \mathrm{ft}$ above tank bottom.

A representation of the PPP and P-350 pump is shown in Figure 3-3.

Figure 3-3. Prefabricated Pump Pit and P-350 Pump

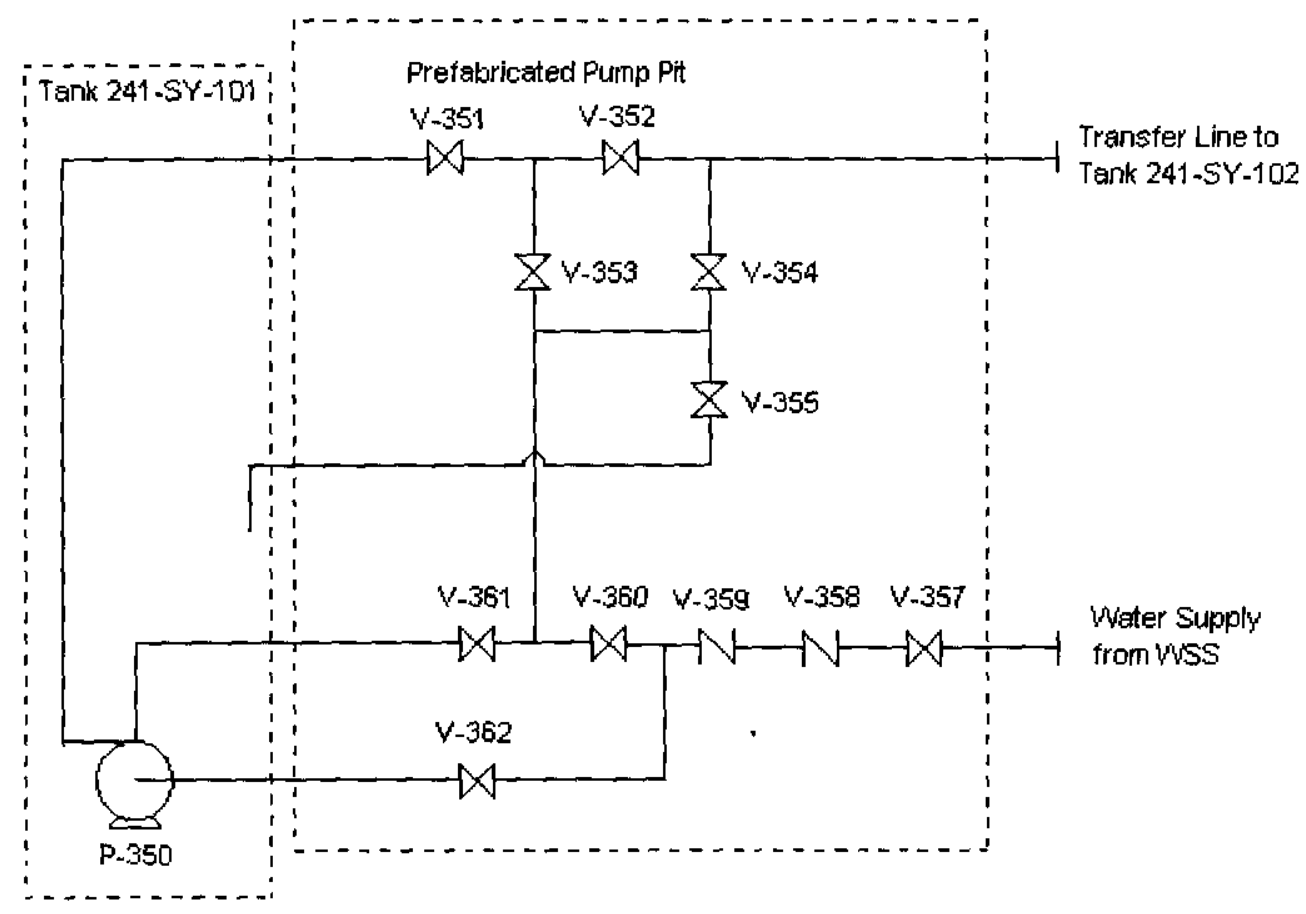


The PPP contains the process routing values listed in Table 3-2

Table 3-2. Prefabricated Pump Pit Valve Functions

\begin{tabular}{|l|l|}
\hline \multicolumn{1}{|c|}{ Valve EIN } & \multicolumn{1}{|c|}{ Description of Valve Function } \\
\hline SY101-WT-V-351 & Transfer Pump Outlet Isolation Valve \\
\hline SY101-WT-V-352 & Transfer Line Isolation Valve \\
\hline SY101-WT-V-353 & Transfer Line Flush Isolation Valve \\
\hline SY101-WT-V-354 & Downstream Vent Valve \\
\hline SY101-WT-V-355 & Upstream Vent Valve \\
\hline SY101-WT-V-357 & Raw Water Isolation Valve \\
\hline SY101-WT-V-358 & Raw Water Upstream Check Valve \\
\hline SY101-WT-V-359 & Raw Water Downstream Check Valve \\
\hline SY101-WT-V-360 & Raw Water Flush Isolation Valve \\
\hline SY101-WT-V-361 & Pump Flush Isolation Valve \\
\hline SY101-WT-V-362 & Pump Dilution Water Isolation Valve \\
\hline
\end{tabular}

\subsection{WASTE TRANSFER LINE}

The waste transfer line is an overground, 2-inch ID, flexible hose-in-hose conveying system wastes at velocities of $6 \mathrm{ft} / \mathrm{sec}(60 \mathrm{gpm})$ or greater. The primary hose is encased in a flexible 4-inch ID hose. The transfer line incorporates bends with radii no less than five line diameters to minimize flow disruptions and associated probability of solids deposition. The transfer hose assembly is approximately $125 \mathrm{ft}$ long, the slope of $1 / 33$ to 1/16. Heat tracing is wrapped around the outside of the encasement hose and a layer of insulation is applied over the assembly. Portable lead blankets provide radiation shielding for the transfer line assembly.

\subsection{TANK 241-SY-102 DROP LEG}

A submerged drop leg at tank 241-SY-102 is incorporated to minimize SY-Farm ventilation system ammonia and volatile organic compound (VOC) concentrations. This device is known as the anti-siphoning slurry distributor (ASSD). The design detail of the ASSD is shown in Figure 3-4.

The primary purpose of the ASSD is to minimize the direct contact of tank 241-SY-101 convective wastes with tank atmosphere. This purpose was justified based on ammonia characterization information for tank 241-SY-101 wastes (e.g., Herting 1995) and engineering analysis of subsequent waste ammonia behavior when exposed to a tank atmosphere (Hedengren 1999). Minimizing the direct contact of the tank 241-SY-101 wastes with the air minimizes the mass transfer of ammonia from the waste slurry to the tank atmosphere. A short air gap is incorporated in the drop leg as protection against tank-to-tank siphoning of wastes. Additionally, by submerging the drop leg discharge, the ammonia in the transferred wastes will seek to enter liquid phase equilibrium with the large amount of aqueous tank 241-SY-102 supernate. By being rapidly absorbed into this supernate, the probability of large, immediate ammonia releases from tank 241-SY-102 will be minimized. 
Along with its primary function, the design of the ASSD incorporates other performance enhancing features.

The drop leg discharge design injects the transferred wastes into tank 241-SY-102 horizontally at a depth of 160 inches. To accomplish this, the drop leg discharge has openings in the horizontal direction, diverting the flow from the axial to the radial direction in the tank. This design and location minimizes the probability of disturbing the presently settled solids of high transuranic (TRU) activity while providing reasonable mixing of the incoming wastes considering the waste volumes and flow rates involved. The horizontal openings at the discharge are sized to maintain a total flow cross-sectional area at least equivalent to that of the 2 -inch transfer line. 


\section{HNF-4264 REV. 2}

Figure 3-4. Anti-Siphoning Slurry Distributor Detail

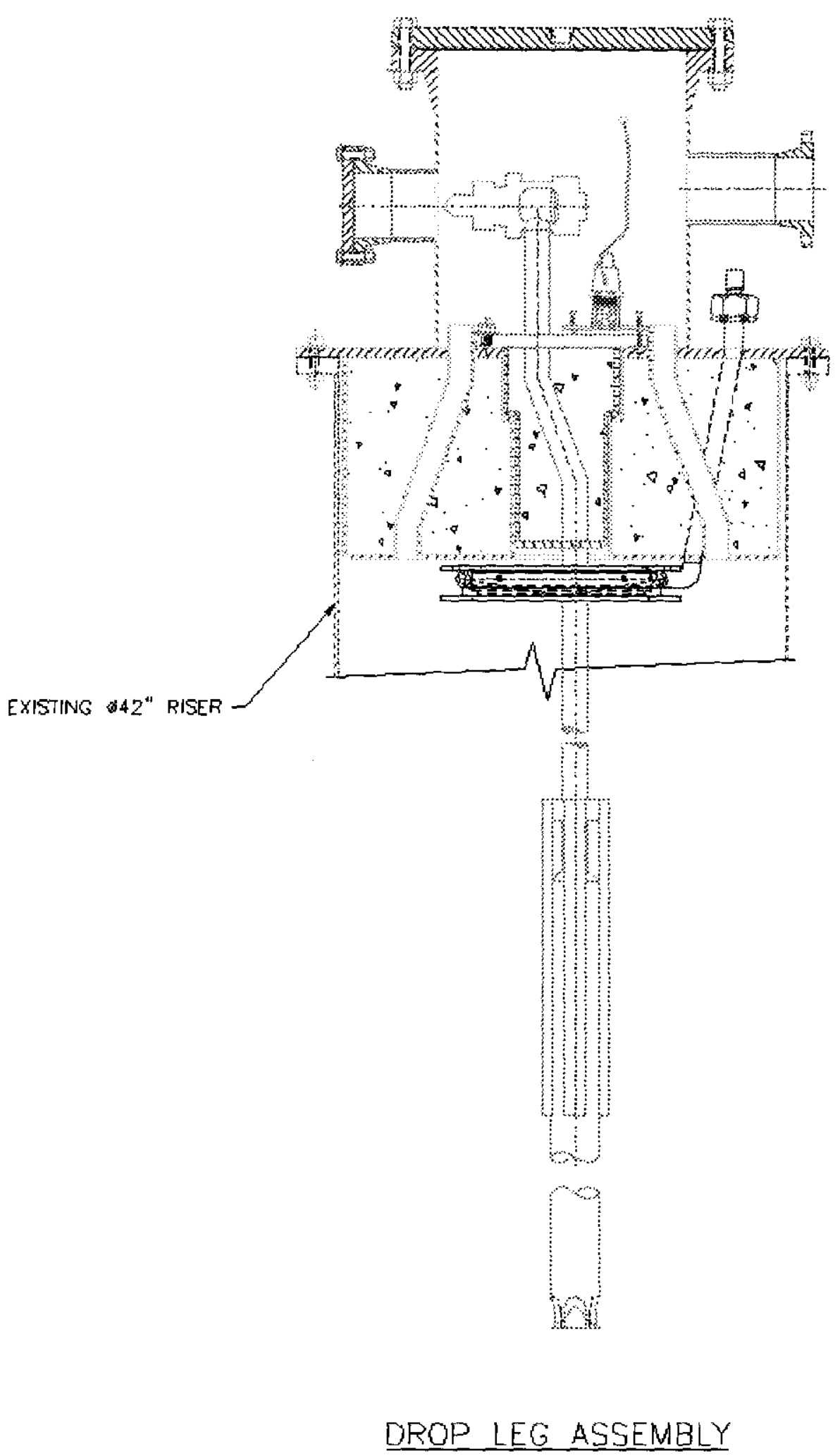


The ASSD also serves as a passive siphon break device for the transfer system. At the top of the drop leg, the 2 -inch diameter transfer-line pipe ends in a nozzle. At this location, the 2-inch diameter pipe transitions to a 4-inch diameter pipe through a diffuser. The diffuser narrows around the 2 -inch pipe, but leaves a quarter-inch air gap between the 4-inch and 2 -inch pipes. This air-gap provides a vacuum break to protect against tank-to-tank siphoning while minimizing the amount of process fluid entering the tank headspace through the air gap.

The drop leg discharge is positioned at 160 inches to achieve a balance among:

(1) Concerns against minimizing agitation of the TRU settled solids in tank 241-SY-102 while optimizing mixing of incoming tank 241-SY-101 slurry with tank 241-SY-102 supernate indicate the drop leg discharge should be located as high off the bottom as possible.

(2) Desiring to maximize the operating volumes in tank 241-SY-102 indicates a location as close to the bottom as possible. This would allow larger batch transfers out of tank 241-SY-102 without exposing the drop leg nozzles to atmosphere - a situation not desired because of the ammonia issues associated with tank 241-SY-101 wastes.

(3) A 160-inch liquid level in tank 241-SY-102 satisfies the operational requirement to keep the waste level higher than 130 inches, minimizing the possibility of entrainment of TRU solids during transfers out of the tank.

\subsection{TRANSFER CONTROL SYSTEM}

The manual positioning of the system routing values and operation of the system pumps achieves control of the waste transfer system.

The pumps are the P-350 transfer pump and the water supply pumps (P-401 and P-402) on the Water Support Skid (WSS). Control of the water pumps is via on/off switches. Pump P-350 incorporates a variable frequency drive (VFD) so in addition to the on/off switches, the pump speed is controlled via a keypad.

Limited instrumentation capability is provided with the system. Mass flow/flow density capabilities are not included in the design because of the short runs of system lines and the short transit times incorporated with them severely limit the response time required to control the composition of the transfer line slurry. Cost and schedule limitations also precluded the incorporation of this sort of instrumentation. Controlling the volumetric ratio of the transfer line flow rate to the dilution water flow rate (valve $V-410$ position and/or pump P-350 speed) provides control of mass flow and density. 
The prime operational concerns are protected by a limited system of interlocks and design features. These operational concerns and the associated interlocks/alarms/design features (shown in parenthesis) are listed below:

(1) Do not fill the transfer line with undiluted waste or water supply lines with any waste upon an electrical or mechanical failure (protective features include (a) interlock to shutdown pump P-350 upon detection of low dilution water flow at the farm control panel; (b) interlock to shutdown of pump P-350 upon detection of high dilution water flow at the farm control panel, (c) alarm indicating high pressure upstream the flush water isolation during transfer operations; (d) two process water check valves V-358 and V-359 in the PPP; (e) the nitrogen pressurized water flush tank on the water support skid ).

(2) Do not allow an electrical or mechanical failure to result in uncontrolled water addition to tanks $241-\mathrm{SY}-101$ or -102 (protective features include the 2,000-gal capacity of the water skid supply tank, which ensures no more than 2,000 gallons of water can be added to the tanks upon loss of electrical power).

Instrumentation and controls are provided at four locations for the transfer system. These are:

- The Farm control panel where the PPP routing and control valves are positioned and operated, and a pump P-350 shutdown switch is provided. Local leak detection alarms are provided for the PPP and transfer line.

- The Remote control location (DACS [Data Acquisition and Control System] control console). The on-off switch is located here. A summary alarm is provided for all leak detection systems.

- The water skid (Water Skid control console). This location provides the water supply valve and pump controls.

- The Motor Control Center (MCC) where the P-350 pump VFD is located.

Table 3-3 lists specific instrumentation and controls associated directly with the waste transfer system. 
HNF-4264 REV. 2

Table 3-3. Transfer System Controls, Indications, Interlocks and Alarms

\begin{tabular}{|c|c|c|}
\hline Type & Description & Location \\
\hline \multirow[t]{4}{*}{ Control } & P-350 pump on/off & $\mathrm{DCP}, \mathrm{MCC}$ \\
\hline & P-350 pump shutoff & $\overline{\mathrm{FCP}}, \overline{\mathrm{DCP}}, \overline{\mathrm{MCC}}$ \\
\hline & P-350 pump speed control/setting & $\overrightarrow{\mathrm{MCC}}$ \\
\hline & Transfer system valve position administrative control & PPP, WSS \\
\hline \multirow{16}{*}{ Indication } & P-350 pumn on/off & $\widehat{\mathrm{FCP} D \mathrm{DCP}}$ \\
\hline & $\mathrm{P}-401 / \mathrm{P}-402$ on/off & $\overline{\mathrm{WSCP}}$ \\
\hline & Transfer line volumetric flow rate indication & $\overline{\mathrm{FCP}}, \mathrm{DCP}$ \\
\hline & Transfer line volumetric flow totalizer & $\overline{F C P}, \overline{D C P}$ \\
\hline & Transfer line temperature indication & $\mathrm{FCP}, \overline{\mathrm{DCP}}$ \\
\hline & Transfer line pressure indication & $\mathrm{FCP}$ \\
\hline & Process water volumetric flow rate indication & WSCP, FCP \\
\hline & Process water volumetric flow totalizer & WSCP, FCP \\
\hline & WSS inlet hose temperature & WSCP \\
\hline & TK-401 temperature & WSCP \\
\hline & WSS discharge hose temperature & WSCP \\
\hline & WSS accumulator temperature & WSCP \\
\hline & Process water supply pressure at WSS & WSCP \\
\hline & Process water supply pressure at PPP & FCP \\
\hline & Process water supply temperature at PPP & FCP, DCP \\
\hline & Flush line isolation pressure & FCP, DCP \\
\hline \multirow[t]{3}{*}{ Interlock } & Process water high/low flow rate shuts down pump P-350 & FCP \\
\hline & TK-401 low-low water level shuts off TK-401 heat trace & WSS \\
\hline & $\begin{array}{l}\text { TK-401 high-high water level or WSS power failure shuts off WSS } \\
\text { inlet water supply }\end{array}$ & \\
\hline \multirow[t]{6}{*}{ Alarm } & PPP and transfer line/drop leg leak detection indication & FCP, DCP, local \\
\hline & Low process water supply temperature & FCP, DCP \\
\hline & PPP transfer line-up V-353 leak-by pressure switch & FCP, DCP \\
\hline & TK-401 low water level & WSCP \\
\hline & TK-401 high water level & WSCP \\
\hline & Flush line isolation pressure & FCP, DCP \\
\hline
\end{tabular}

$\mathrm{DCP}=\mathrm{DACS}$ Control Panel

$\mathrm{FCP}=$ Farm Control Panel

$\mathrm{MCC}=$ Motor Control Center

WSS $=$ Water Support Skid

WSCP $=$ Water Skid Control Panel 
HNF-4264 REV. 2

This page intentionally left blank. 


\subsection{PROCESS FLOWSHEET}

The tank 241-SY-101 waste transfer system is a slurry pumping system. The design provides for heated water dilution at the inlet of the waste transfer pump to permit control of important transport and other physical properties. It provides pre-heating, water flushing and flow velocity in the waste transfer lines both to minimize the probability of solids formation as well as subsequent solids settling in the lines. The system incorporates three independent design features to minimize the probability of inadvertent waste transfer. These siphon break features include the transfer line vent valves in the PPP, the air gap in the tank 241-SY-102 drop leg, and the air gap in tank TK-401. The siphon breaks in the WSS and the tank 241-SY-102 drop-leg are passive design features. The siphon break in the PPP requires manual valve operation. Administrative control of system valve positions also provides this function. Further design and operational control features are incorporated to satisfy the requirements or recommendations made by the TWRS Authorization Basis, Environmental, Industrial Hygiene, and Safety controls, as well as Operational Specification Controls and Good Operating Practices. Primary among the latter are features to protect against waste solidification in the transfer lines.

Figure 4-1 shows indicates the process flowsheet for the transfer system. 
Figure 4-1. RAPID Transfer System Process Flowsheet

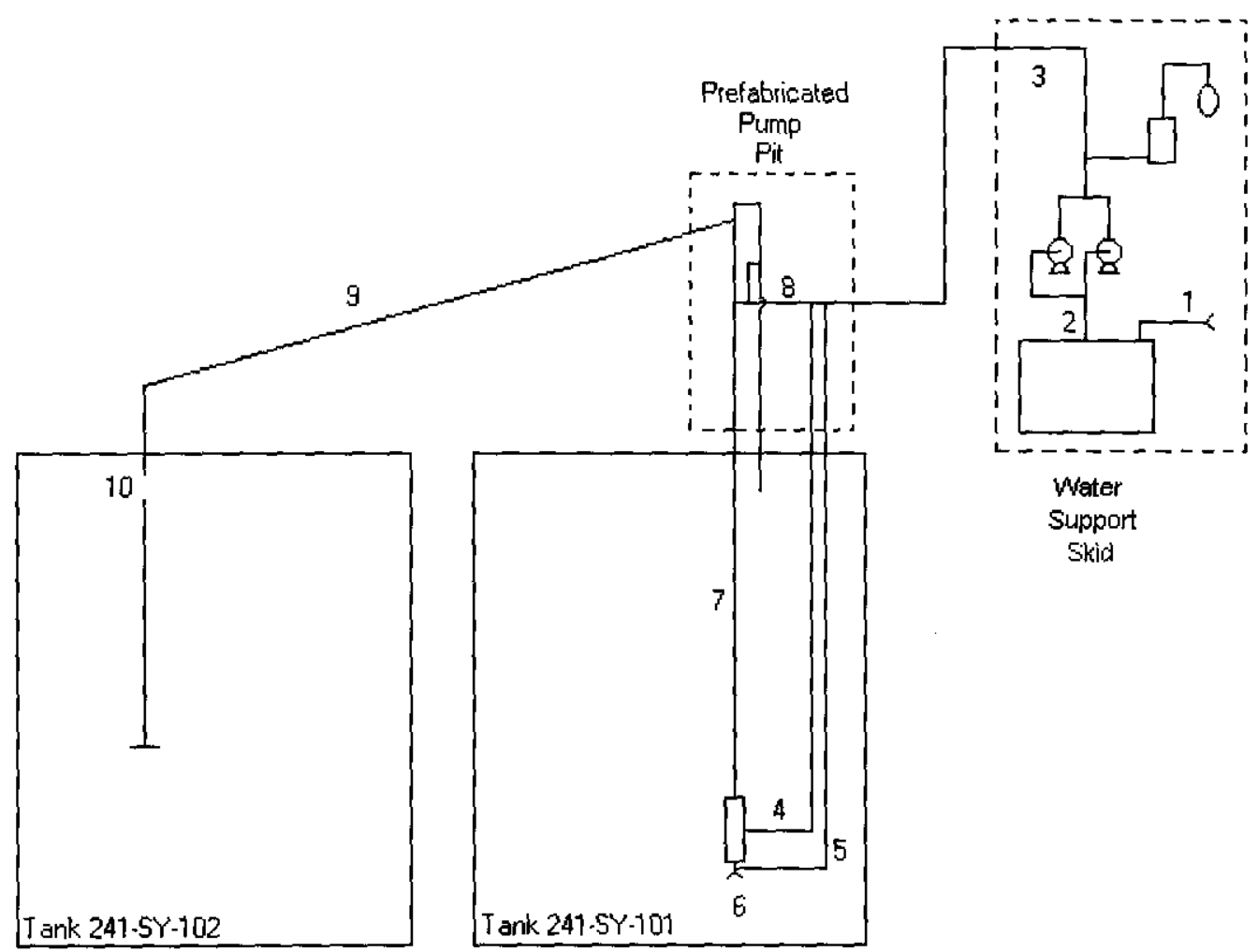

\section{RAPID Transfer System Process Flows}

(1) TK-401 Inlet

(2) TK-401 Outlet

(3) PPP Water Supply

(4) P-350 Pump Internal Flush

(5) P-350 Pump Dilution Water

(6) P-350 Pump Waste Inlet

(7) P-350 Pump Discharge

(8) Flush Cross Connect

(9) Transfer Line

(10) Siphon Break 


\subsection{RAPID TRANSFER SYSTEM CONFIGURATION}

The transfer system valve arrangement is indicated in Figure 4-1 with the nomenclature described in Table 4-1. This listing of valves constitutes the process valves in the transfer system and is used in describing the line-ups of operation.

Figure 4-2. RAPID Transfer System Schematic

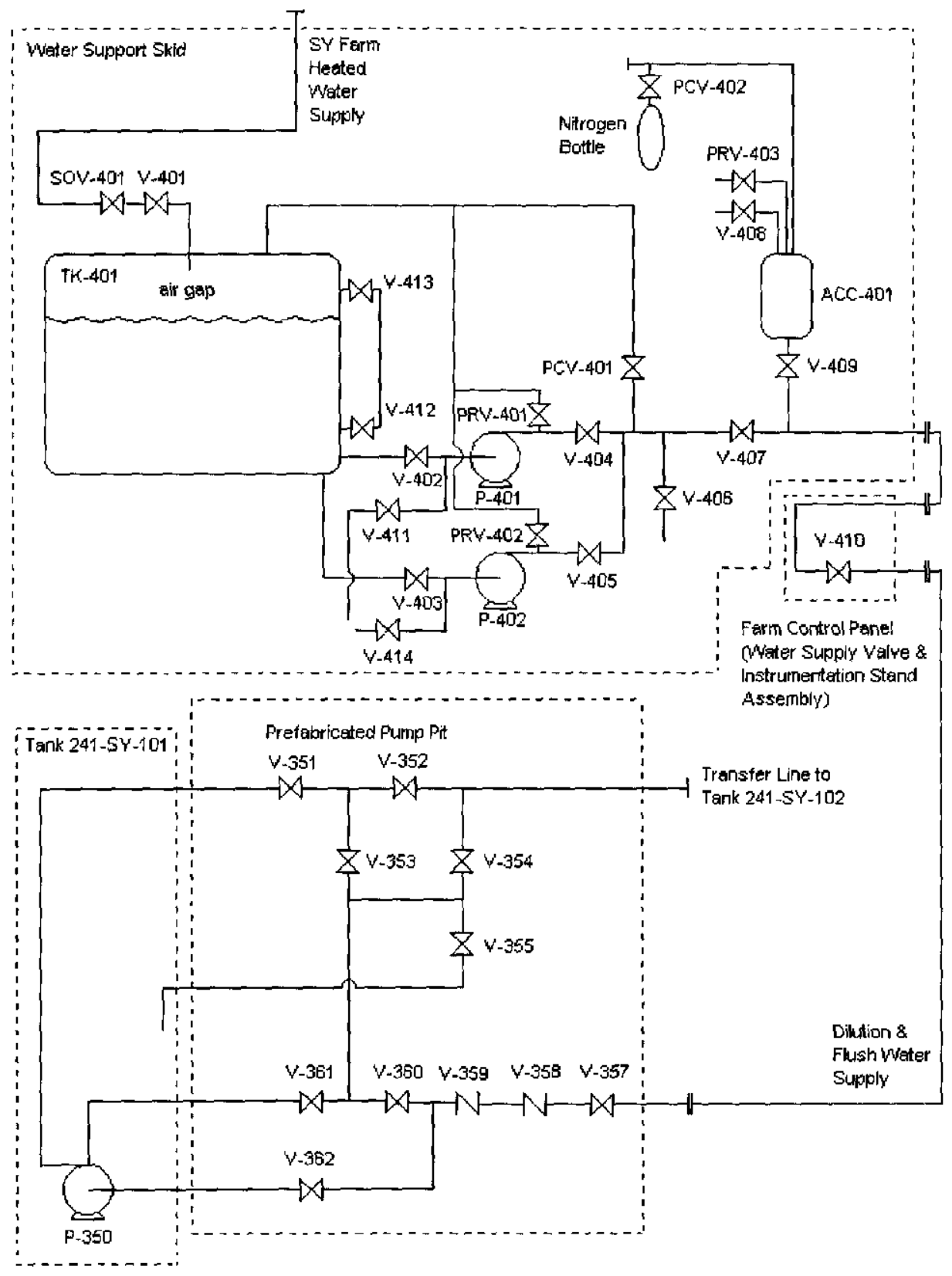


HNF-4264 REV. 2

Table 4-4-1. RAPID Transfer System Valve Nomenclature

\begin{tabular}{|c|c|}
\hline Nalve EIN & Valve Function \\
\hline *SOV-401 & WSS: Raw Water Supply to Skid Solenoid Operated Isolation \\
\hline$* \mathrm{PCV}-401$ & WSS: Raw Water Outlet Line Pressure Control Valve \\
\hline$* \mathrm{PCV}-402$ & WSS: Accumulator Pressure Control Valve \\
\hline$* \mathrm{PRV}-401$ & WSS: P-401 Outlet Line Pressure Relief Valve \\
\hline *PRV-402 & WSS: P-402 Outlet Line Pressure Relief Valve \\
\hline *PRV -403 & WSS: Accumulator ACC-401 Pressure Relief Valve \\
\hline$* V-401$ & WSS: Raw Water Supply to Skid Isolation Valve \\
\hline$* V-402$ & WSS: Pump P-40I Inlet Isolation Valve \\
\hline$* V-403$ & WSS: Pump P-402 Inlet Isolation Valve \\
\hline$* V-404$ & WSS: Pump P-401 Outlet Isolation Valve \\
\hline$* V-405$ & WSS: Pump P-402 Outlet Isolation Valve \\
\hline$* \mathrm{~V}-406$ & WSS: Flush Drain Isolation Valve \\
\hline$* \mathrm{~V}-407$ & WSS: Outlet Line Isolation Valve \\
\hline$* V-408$ & WSS: Accumulator ACC-401 Vent Isolation Valve \\
\hline$* V-409$ & WSS: Accumulator ACC-401 Isolation Valve \\
\hline$* V-410$ & FCP: Valve Stand Raw Water Line Isolation Valve \\
\hline$* V-411$ & WSS: Pump Inlet Line Drain Isolation Valve \\
\hline$* V-412$ & WSS: Tank TK-401 Sight-Glass Lower Isolation Valve \\
\hline$* V-413$ & WSS: Tank TK-401 Sight-Glass Upper Isolation Valve \\
\hline$* V-414$ & WSS: Pump Inlet Line Drain Isolation Valve \\
\hline$* * V-351$ & PPP: Transfer Pump Outlet Isolation Valve \\
\hline$* * \mathrm{~V}-352$ & PPP: Transfer Line Isolation Valve \\
\hline$* * V-353$ & PPP: Transfer Line Flush Isolation Valve \\
\hline$* * V-354$ & PPP: Downstream Vent Valve \\
\hline$* * \mathrm{~V}-355$ & PPP: Upstream Vent Valve \\
\hline$* * V-357$ & PPP: Raw Water Isolation Valve \\
\hline$* * V-358$ & PPP: Raw Water Upstream Check Valve \\
\hline$* * \mathrm{~V}-359$ & PPP: Raw Water Downstream Check Valve \\
\hline$* * V-360$ & PPP: Raw Water Flush Isolation Valve \\
\hline$* * V-361$ & PPP: Pump Flush Isolation Valve \\
\hline$* * V-362$ & PPP: Pump Dilution Water Isolation Valve \\
\hline
\end{tabular}

Key:

* valve EIN begins with POR32-RW-

** valve EIN begins with SY101-WT-

$\mathrm{FCP}=$ Farm Control Panel

PPP $=$ Prefabricated Pump Pit

WSS $=$ Water Support Skid 
HNF-4264 REV. 2

\title{
4.2 RAPID TRANSFER SYSTEM PROCESS FLOW VALVE LINE-UPS
}

Standby

Flush or Preheat Line-ups

- Transfer Line Flush

- Transfer Line Back-Flush

- P-350 Pump Purge

- Siphon Break Flush to Transfer Line

ACC-401 Transfer Line Flush

ACC-401 Transfer Line Back-Flush

\section{Waste Transfer}

Tank Water Addition via Transfer Pump Dilution Line

Tank Water Addition via Transfer System Vent Line

\begin{abstract}
Notes
For Tank back-dilution: The initial tank back-dilution of tank 241-SY-101 is accomplished by the already existing infrastructure provided by the transfer system. When the transfer system is back-flushed, or the transfer pump purged, or dilution water supplied to the transfer pump (see Sections 5.3, 5.4 and 5.9), water is directly added to the convective waste at a tank level of 96 inches. When dilution water is supplied through valve V-355 (see Section 4.2.10), the water is added directly to the top of the crust. These tank back-dilution flow rates are controlled via valve V-410. No temperature controls are required for the tank back-dilution water supplied through the PPP. Control of the process is achieved via feedback from the tank level changes, in-tank video observations, and continuous monitoring of the tank off gassing.

\section{Explanation Valve Line-Up Tables}

(N/A ): not applicable, as this section of process piping is valved out from the piping sections in active use - or - this parameter has no meaning for the flow mode in question.

( - ): process piping is in active use but the parameter value is not of specific concern to the process. However, specification of parameter value/limits requires prudent engineering judgement

( R ): symbol used for waste transfer operations expressing the required transfer flow rate as a variable to be optimized depending upon determination of the process piping diameter. Waste transfer flow control is specifically stated as a flow velocity requirement as opposed to a flow rate requirement. Specifying the transfer flowrate as a variable allows the convenient expression of the allowable waste and dilution water flowrates.

For process line flushes, the primary objective is to simply displace process waste fluid from the lines and replace it with fresh water. Prudent engineering suggests that additional requirements be stated to 


\section{HNF-4264 REV. 2}

maximize the efficiency of the flush within the limits of the RAPID infrastructure (i.e., a volumetric flush water flow rate of $70 \mathrm{gpm}$ ). The specified process line flush volume is equal to the larger of either:

-two times the volume of the process line being flushed

-two minutes of flow at the specified line flow velocity

The process line flush flow rate is specified as $4 /$ sec $106 \%$ sec. This velocity is estimated to meet critical velocity requirements for the process lines.

The transfer pump internal fush requirement is stated as flow rate of approximately $10 \mathrm{gpm}$. The transfer pump internal flush volume and temperature limits are then defined by the limits on water addition to tank 241-SY-101 (i.e., a volume not to exceed the capacity of the water skid tank that is within the water addition temperature limits of $102^{\circ} \mathrm{F}$ to $130^{\circ} \mathrm{F}$ ). 


\subsubsection{Standby}

\begin{tabular}{|l|l|}
\hline $\begin{array}{l}\text { Process Flow Line-up } \\
\text { Standby }\end{array}$ & $\begin{array}{l}\text { This line-up constitutes the de-energized or standby lineup of the } \\
\text { transfer system. All system valves are shut except the sight-glass } \\
\text { isolation valves on TK-401. } \\
\text { Pumps P-350, P-401, P-402 are de-energized }\end{array}$ \\
\hline
\end{tabular}

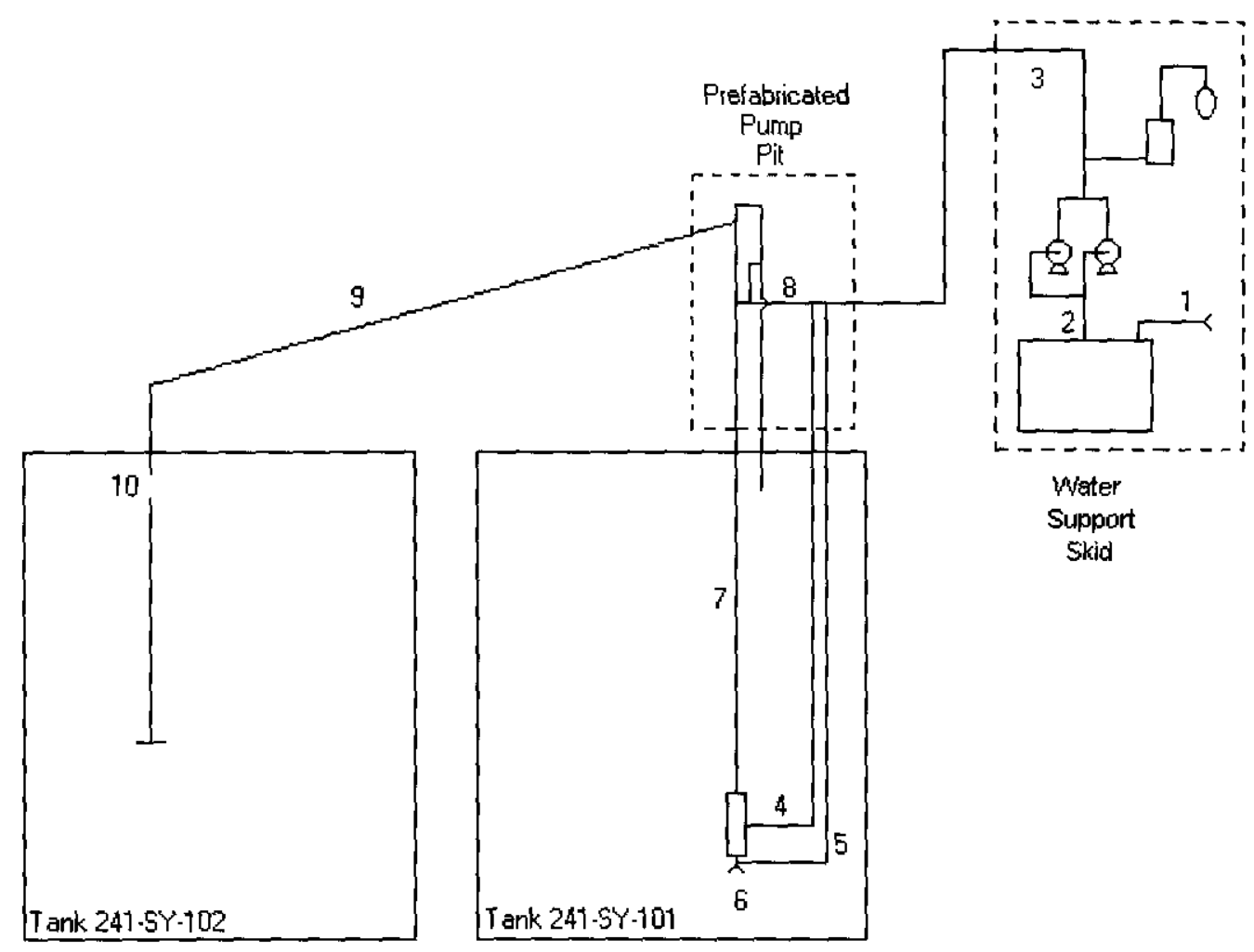


HNF-4264 REV. 2

Permissible Process Limits for Standby Condition

\begin{tabular}{|c|c|c|c|c|c|c|c|c|c|}
\hline $\begin{array}{c}\text { Flow } \\
\text { Parameter }\end{array}$ & $\begin{array}{l}\text { Water } \\
\text { Skid } \\
\text { Inlet } \\
(1)\end{array}$ & $\begin{array}{l}\text { Water } \\
\text { Skid } \\
\text { Outlet } \\
(2)\end{array}$ & $\begin{array}{l}\text { PPP } \\
\text { Water } \\
\text { Supply } \\
\text { Line } \\
(3)\end{array}$ & $\begin{array}{c}\text { Transfer } \\
\text { Pump } \\
\text { Internal } \\
\text { Flush } \\
\text { Line } \\
(4) \\
\end{array}$ & $\begin{array}{c}\text { Transfer } \\
\text { Pump } \\
\text { Water } \\
\text { Supply } \\
\text { Line } \\
\text { (5) }\end{array}$ & $\begin{array}{l}\text { Transfer } \\
\text { Pump } \\
\text { Waste } \\
\text { Inlet } \\
(6)\end{array}$ & $\begin{array}{l}\text { Transfer } \\
\text { Pump } \\
\text { Outlet } \\
(7)\end{array}$ & $\begin{array}{l}\text { Flush } \\
\text { Cross- } \\
\text { Connect } \\
(8)\end{array}$ & $\begin{array}{l}\text { Transfer } \\
\text { Line } \\
(9)\end{array}$ \\
\hline $\begin{array}{l}\text { Flow } \\
\text { Rate }\end{array}$ & $\mathrm{N} / \mathrm{A}$ & $\bar{N} / \mathrm{A}$ & $\bar{N} / \bar{A}$ & $\bar{N} / \mathrm{A}$ & $\bar{N} / \bar{A}$ & N/A & N/A & N/A & N/A \\
\hline $\begin{array}{c}\text { Flush } \\
\text { Volume }\end{array}$ & N/A & $\mathrm{N} / \mathrm{A}$ & N/A & $\mathrm{N} / \mathrm{A}$ & $\mathrm{N} / \mathrm{A}$ & $\mathrm{N} / \mathrm{A}$ & $\mathrm{N} / \mathrm{A}$ & $\mathrm{N} / \mathrm{A}$ & N/A \\
\hline $\begin{array}{c}\text { Flow } \\
\text { Velocity } \\
(\mathrm{t} / \mathrm{sec})\end{array}$ & $\bar{N} / \mathrm{A}$ & N/A & $\mathrm{N} / \mathrm{A}$ & $\mathrm{N} / \mathrm{A}$ & N/A & N/A & N/A & N/A & N/A \\
\hline $\begin{array}{l}\text { Temperature } \\
\left({ }^{\circ} \mathrm{F}\right)\end{array}$ & N/A & N/A & N/A & N/A & N/A & N/A & N/A & N/A & N/A \\
\hline $\begin{array}{l}\text { Viscosity } \\
\text { (cP) }\end{array}$ & N/A & N/A & $\mathrm{N} / \mathrm{A}$ & N/A & N/A & N/A & N/A & N/A & $\mathrm{N} / \mathrm{A}$ \\
\hline $\begin{array}{l}\text { Density } \\
(\text { grams } / c \text { c })\end{array}$ & $\mathrm{N} / \mathrm{A}$ & N/A & $\bar{N} / \mathrm{A}$ & N/A & N/A & $\mathrm{N} / \mathrm{A}$ & $\overline{\mathrm{N}} / \overline{\mathrm{A}}$ & $\mathrm{N} / \mathrm{A}$ & $\overline{\mathrm{N} / \mathrm{A}}$ \\
\hline $\begin{array}{c}\text { Volume \% } \\
\text { Solids }\end{array}$ & $\mathrm{N} / \mathrm{A}$ & N/A & N/A & N/A & $\mathrm{N} / \mathrm{A}$ & $\mathrm{N} / \mathrm{A}$ & N/A & N/A & N/A \\
\hline $\begin{array}{c}\text { Mass \% } \\
\text { Water }\end{array}$ & $\mathrm{N} / \mathrm{A}$ & $\mathrm{N} / \mathrm{A}$ & $\mathrm{N} / \mathrm{A}$ & $\mathrm{N} / \mathrm{A}$ & $\overline{\mathrm{N}} / \overline{\mathrm{A}}$ & $\overline{\mathrm{N}} / \overline{\mathrm{A}}$ & $\bar{N} / \mathrm{A}$ & $\mathrm{N} / \mathrm{A}$ & $\mathrm{N} / \mathrm{A}$ \\
\hline $\begin{array}{c}\text { Mass \% } \\
\text { Completely } \\
\text { Insoluble } \\
\text { Solids }\end{array}$ & N/A & $\mathrm{N} / \mathrm{A}$ & N/A & $\mathrm{N} / \mathrm{A}$ & $\mathrm{N} / \mathrm{A}$ & $\mathrm{N} / \mathrm{A}$ & $\mathrm{N} / \mathrm{A}$ & $\bar{N} / \mathrm{A}$ & $\bar{N} / \mathrm{A}$ \\
\hline
\end{tabular}




\subsubsection{Transfer Line Flush}

\begin{tabular}{|l|l|}
\hline Process Flow Line-up & \multicolumn{1}{|c|}{ Line-up Notes and General Procedure } \\
Transfer Line Flush & $\begin{array}{l}\text { This line-up is established immediately prior to or immediately } \\
\text { following waste transfer operations, to either flush or pre-heat } \\
\text { system lines. } \\
\text { P-350 is de-energized / P-401 or P-402 is energized and running as } \\
\text { necessary to provide flush water pressure/flow rate as needed: } \\
\bullet \quad 2 \times \text { line volumes or } 2 \text { minutes of flow, which-ever is greater } \\
\qquad \quad 102{ }^{\circ} \mathrm{F} \text { to } 130^{\circ} \mathrm{F} \\
\text { flow rate not to exceed } 70 \text { gpm } \\
\text { when possible, flush flow velocity should exceed } 4 \mathrm{ft} / \mathrm{sec}\end{array}$ \\
\hline
\end{tabular}

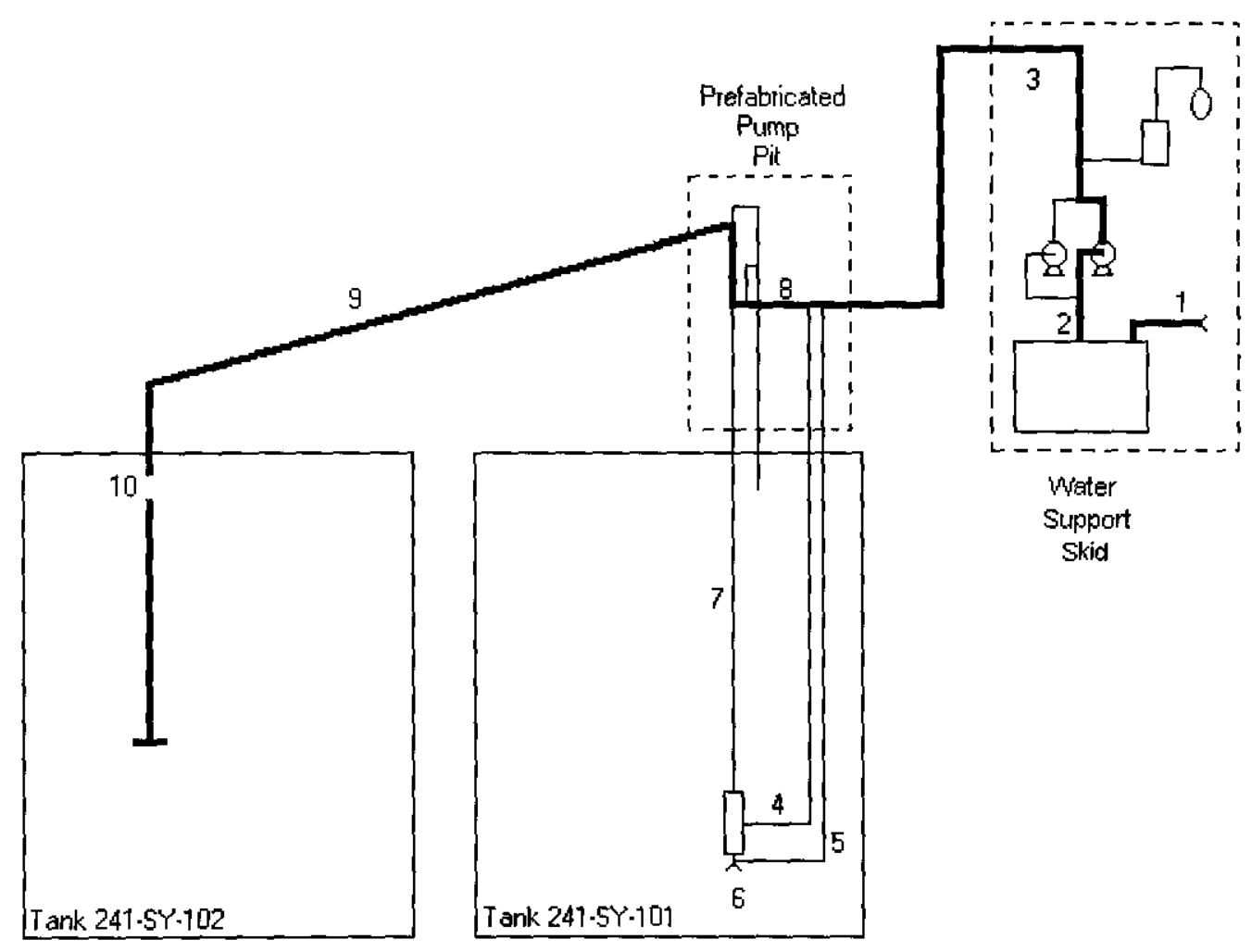


HNF-4264 REV. 2

Permissible Process Limits for Transfer Line Flush

\begin{tabular}{|c|c|c|c|c|c|c|c|c|c|}
\hline $\begin{array}{c}\text { Flow } \\
\text { Parameter }\end{array}$ & $\begin{array}{l}\text { Water } \\
\text { Skid } \\
\text { Inlet } \\
(1)\end{array}$ & $\begin{array}{l}\text { Water } \\
\text { Skid } \\
\text { Outlet } \\
(2)\end{array}$ & $\begin{array}{l}\text { PPP } \\
\text { Water } \\
\text { Supply } \\
\text { Line } \\
\text { (3) }\end{array}$ & $\begin{array}{l}\text { Transfer } \\
\text { Pump } \\
\text { Internal } \\
\text { Flush } \\
\text { Line } \\
\text { (4) }\end{array}$ & $\begin{array}{l}\text { Transfer } \\
\text { Pump } \\
\text { Water } \\
\text { Supply } \\
\text { Line } \\
\text { (5) }\end{array}$ & $\begin{array}{l}\text { Transfer } \\
\text { Pump } \\
\text { Waste } \\
\text { Inlet } \\
(6)\end{array}$ & $\begin{array}{l}\text { Transfer } \\
\text { Pump } \\
\text { Outlet } \\
(7)\end{array}$ & $\begin{array}{l}\text { Flush } \\
\text { Cross } \\
\text { Connect } \\
\text { (8) }\end{array}$ & $\begin{array}{l}\text { Transfer } \\
\text { Line } \\
(9)\end{array}$ \\
\hline $\begin{array}{l}\text { Flow } \\
\text { Rate }\end{array}$ & - & $\begin{array}{l}<70 \\
\text { gpm }\end{array}$ & $\begin{array}{l}<70 \\
\mathrm{gpm}\end{array}$ & N/A & N/A & N/A & N/A & $\begin{array}{l}<70 \\
\text { gpm }\end{array}$ & $\begin{array}{l}<70 \\
\text { gpm }\end{array}$ \\
\hline $\begin{array}{c}\text { Flush } \\
\text { Volume }\end{array}$ & $\begin{array}{l}2 \text { line } \\
\text { volumes } \\
\text { or } 2 \\
\text { minutes } \\
\text { of flow, } \\
\text { which- } \\
\text { ever is } \\
\text { greater }\end{array}$ & $\begin{array}{l}2 \text { line } \\
\text { volumes } \\
\text { or } 2 \\
\text { minutes } \\
\text { of flow, } \\
\text { which- } \\
\text { ever is } \\
\text { greater }\end{array}$ & $\begin{array}{c}2 \text { line } \\
\text { volumes } \\
\text { or } 2 \\
\text { minutes } \\
\text { of flow, } \\
\text { which- } \\
\text { ever is } \\
\text { greater }\end{array}$ & N/A & N/A & N/A & N/A & $\begin{array}{l}2 \text { line } \\
\text { volumes } \\
\text { or } 2 \\
\text { minutes } \\
\text { of flow, } \\
\text { which- } \\
\text { ever is } \\
\text { greater }\end{array}$ & $\begin{array}{l}2 \text { line } \\
\text { volumes } \\
\text { or } 2 \\
\text { minutes } \\
\text { of flow, } \\
\text { which- } \\
\text { ever is } \\
\text { greater }\end{array}$ \\
\hline $\begin{array}{c}\text { Flow } \\
\text { Velocity } \\
(\mathrm{f} / \mathrm{sec})\end{array}$ & - & - & - & N/A & N/A & N/A & N/A & 4 to 6 & 4 to 6 \\
\hline $\begin{array}{l}\text { Temperature } \\
\left({ }^{\circ} \mathrm{F}\right)\end{array}$ & - & $\begin{array}{c}102 \\
\text { to } \\
130\end{array}$ & $\begin{array}{c}102 \\
\text { to } \\
130 \\
\end{array}$ & N/A & N/A & N/A & N/A & $\begin{array}{c}102 \\
\text { to } \\
130\end{array}$ & $\begin{array}{c}102 \\
\text { to } \\
130\end{array}$ \\
\hline $\begin{array}{l}\text { Viscosity } \\
\text { (cP) }\end{array}$ & - & $\begin{array}{c}0.50 \\
\text { to } \\
0.62\end{array}$ & $\begin{array}{c}0.50 \\
\text { to } \\
0.62\end{array}$ & N/A & N/A & N/A & N/A & $\begin{array}{c}0.50 \\
\text { to } \\
0.62 \\
\end{array}$ & $\begin{array}{c}0.50 \\
\text { to } \\
0.62\end{array}$ \\
\hline $\begin{array}{l}\text { Density } \\
\text { (grams/cc) }\end{array}$ & $<1$ & $\leq 1$ & $<1$ & N/A & N/A & N/A & N/A & $<1$ & $<1$ \\
\hline $\begin{array}{l}\text { Volume } \% \\
\text { Solids }\end{array}$ & $<0.01$ & $<0.01$ & $<0.01$ & N/A & $\mathrm{N} / \mathrm{A}$ & N/A & N/A & $<0.01$ & $<0.01$ \\
\hline $\begin{array}{c}\text { Mass \% } \\
\text { Water }\end{array}$ & 100 & 100 & 100 & N/A & N/A & N/A & N/A & 100 & 100 \\
\hline $\begin{array}{c}\text { Mass \% } \\
\text { Completely } \\
\text { Insoluble } \\
\text { Solids }\end{array}$ & 0 & 0 & 0 & N/A & N/A & N/A & N/A & 0 & 0 \\
\hline
\end{tabular}




\subsubsection{Transfer Line Back-Flush}

\begin{tabular}{|c|c|}
\hline $\begin{array}{l}\text { Transfer System } \\
\text { Process Flow Line-up }\end{array}$ & Line-up Notes and General Procedure \\
\hline $\begin{array}{c}\text { Transfer Line } \\
\text { Back-Flush }\end{array}$ & $\begin{array}{l}\text { This line-up is established immediately prior to or immediately } \\
\text { following waste transfer operations, to either flush or pre-heat } \\
\text { system lines or pump P-350. Additionally, this line-up can be used } \\
\text { to add dilution water to the convective waste in the tank through the } \\
\text { transfer pump inlet. } \\
\text { P-350 is de-energized / P- } 401 \text { or P- } 402 \text { is energized and running as } \\
\text { necessary to provide flush water pressure/flow rate as needed: } \\
\text { - } 2 \times \text { line volumes or } 2 \text { minutes of flow, which-ever is greater } \\
\text { - } 102^{\circ} \mathrm{F} \text { to } 130^{\circ} \mathrm{F} \\
\text { - flow rate not to exceed } 70 \text { gpm } \\
\text { - when possible, flush flow velocity should exceed } 4 \mathrm{ft} / \mathrm{sec}\end{array}$ \\
\hline
\end{tabular}

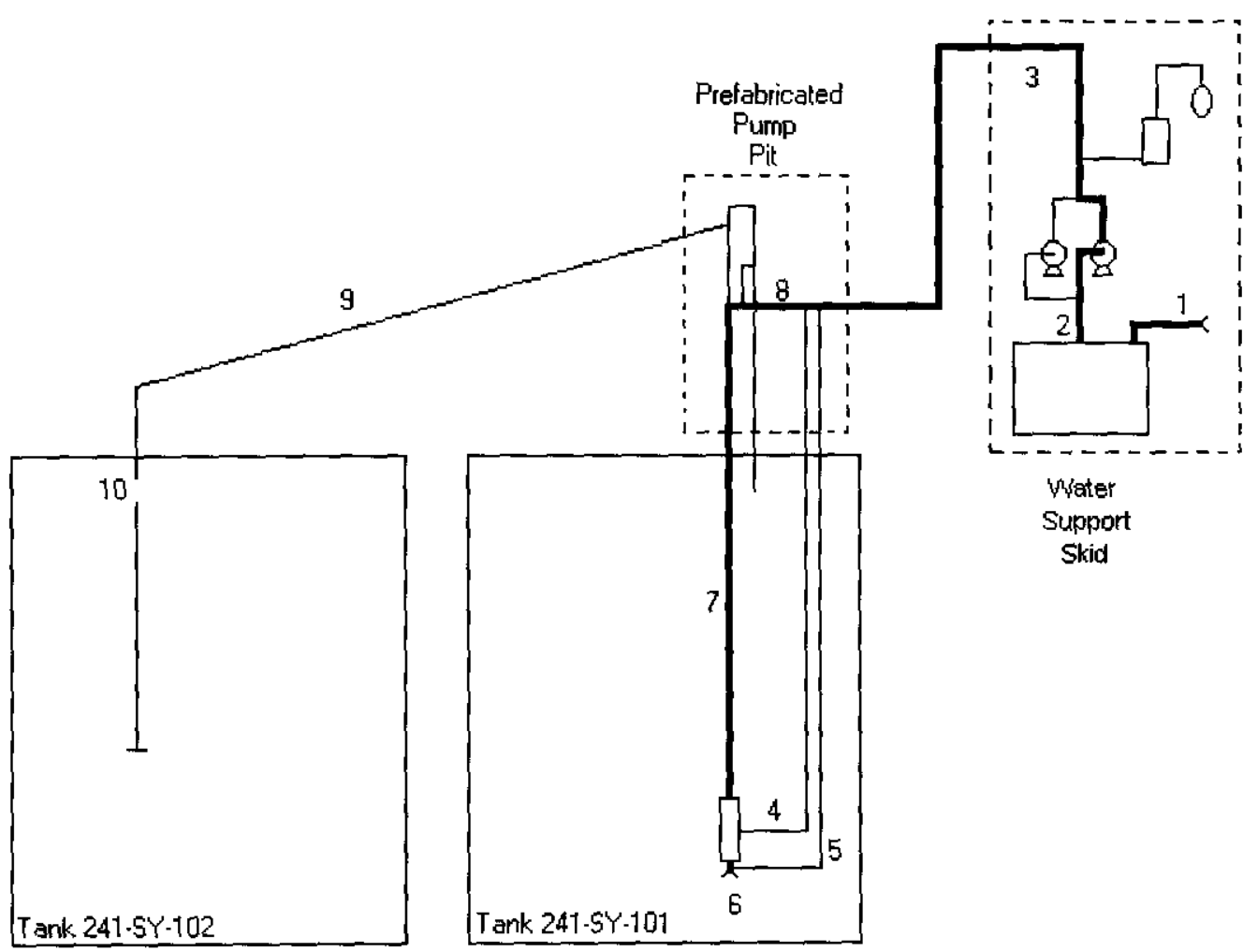


Permissible Process Limits for Transfer Line Back-Flush

\begin{tabular}{|c|c|c|c|c|c|c|c|c|c|}
\hline $\begin{array}{c}\text { Flow } \\
\text { Parameter }\end{array}$ & $\begin{array}{l}\text { Water } \\
\text { Skid } \\
\text { Inlet } \\
\text { (1) }\end{array}$ & $\begin{array}{l}\text { Water } \\
\text { Skid } \\
\text { Outlet } \\
(2)\end{array}$ & $\begin{array}{l}\text { PPP } \\
\text { Water } \\
\text { Supply } \\
\text { Line } \\
\text { (3) }\end{array}$ & $\begin{array}{l}\text { Transfer } \\
\text { Pump } \\
\text { Internal } \\
\text { Flush } \\
\text { Line } \\
(4)\end{array}$ & $\begin{array}{l}\text { Transfer } \\
\text { Pump } \\
\text { Water } \\
\text { Supply } \\
\text { Line } \\
\text { (5) }\end{array}$ & $\begin{array}{l}\text { Transfer } \\
\text { Pump } \\
\text { Waste } \\
\text { Inlet } \\
(6)\end{array}$ & $\begin{array}{l}\text { Transfer } \\
\text { Pump } \\
\text { Outlet } \\
\text { (7) }\end{array}$ & $\begin{array}{l}\text { Flush } \\
\text { Cross- } \\
\text { Connect } \\
(8)\end{array}$ & $\begin{array}{l}\text { Transfer } \\
\text { Line } \\
\text { (9) }\end{array}$ \\
\hline Flow Rate & - & $\begin{array}{l}<70 \\
\mathrm{gpm}\end{array}$ & $\begin{array}{l}<70 \\
\mathrm{gpm}\end{array}$ & N/A & N/A & $\begin{array}{l}<70 \\
\mathrm{gpm}\end{array}$ & $\begin{array}{l}<70 \\
\mathrm{gpm}\end{array}$ & $\begin{array}{l}<70 \\
\mathrm{gpm}\end{array}$ & N/A \\
\hline $\begin{array}{l}\text { Flush } \\
\text { Volume }\end{array}$ & $\begin{array}{l}2 \text { line } \\
\text { volumes } \\
\text { or } 2 \\
\text { minutes } \\
\text { of flow, } \\
\text { which- } \\
\text { ever is } \\
\text { greater }\end{array}$ & $\begin{array}{l}2 \text { line } \\
\text { volumes } \\
\text { or } 2 \\
\text { minutes } \\
\text { of flow, } \\
\text { which- } \\
\text { ever is } \\
\text { greater }\end{array}$ & $\begin{array}{l}2 \text { line } \\
\text { volumes } \\
\text { or } 2 \\
\text { minutes } \\
\text { of flow, } \\
\text { which- } \\
\text { ever is } \\
\text { greater }\end{array}$ & N/A & N/A & $\begin{array}{l}2 \text { line } \\
\text { volumes } \\
\text { or } 2 \\
\text { minutes } \\
\text { of flow, } \\
\text { which- } \\
\text { ever is } \\
\text { greater }\end{array}$ & $\begin{array}{l}2 \text { line } \\
\text { volumes } \\
\text { or } 2 \\
\text { minutes } \\
\text { of flow, } \\
\text { which- } \\
\text { ever is } \\
\text { greater }\end{array}$ & $\begin{array}{l}2 \text { line } \\
\text { volumes } \\
\text { or } 2 \\
\text { minutes } \\
\text { of flow, } \\
\text { which- } \\
\text { ever is } \\
\text { greater }\end{array}$ & N/A \\
\hline $\begin{array}{c}\text { Flow } \\
\text { Velocity } \\
(\mathrm{t} / \mathrm{sec})\end{array}$ & - & - & - & N/A & N/A & - & 4 to 6 & 4 to 6 & N/A \\
\hline $\begin{array}{l}\text { Temperature } \\
\left({ }^{\circ} \mathrm{F}\right)\end{array}$ & - & $\begin{array}{c}102 \\
\text { to } \\
130\end{array}$ & $\begin{array}{c}102 \\
\text { to } \\
130\end{array}$ & N/A & N/A & $\begin{array}{c}102 \\
\text { to } \\
130\end{array}$ & $\begin{array}{c}102 \\
\text { to } \\
130\end{array}$ & $\begin{array}{c}102 \\
\text { to } \\
130\end{array}$ & N/A \\
\hline $\begin{array}{l}\text { Viscosity } \\
\text { (cP) }\end{array}$ & - & $\begin{array}{c}0.50 \\
\text { to } \\
0.62\end{array}$ & $\begin{array}{c}0.50 \\
\text { to } \\
0.62\end{array}$ & N/A & N/A & $\begin{array}{c}0.50 \\
\text { to } \\
0.62\end{array}$ & $\begin{array}{c}0.50 \\
\text { to } \\
0.62\end{array}$ & $\begin{array}{c}0.50 \\
\text { to } \\
0.62 \\
\end{array}$ & N/A \\
\hline $\begin{array}{l}\text { Density } \\
(\text { grams/co) }\end{array}$ & $<1$ & $<1$ & $<1$ & N/A & N/A & $<1$ & $<1$ & $<1$ & N/A \\
\hline $\begin{array}{l}\text { Volume } \% \\
\text { Solids }\end{array}$ & $<0.01$ & $<0.01$ & $<0.01$ & N/A & N/A & $<0.01$ & $<0.01$ & $<0.01$ & N/A \\
\hline $\begin{array}{c}\text { Mass \% } \\
\text { Water }\end{array}$ & 100 & 100 & 100 & N/A & N/A & 100 & 100 & 100 & N/A \\
\hline $\begin{array}{l}\text { Mass \% } \\
\text { Completely } \\
\text { Insoluble } \\
\text { Solids }\end{array}$ & 0 & 0 & 0 & N/A & N/A & 0 & 0 & 0 & N/A \\
\hline
\end{tabular}




\subsubsection{Pump P-350 Purge}

\begin{tabular}{|l|l|}
\hline $\begin{array}{c}\text { Transfer System } \\
\text { Process Flow Line-up }\end{array}$ & $\begin{array}{l}\text { This line-up is established prior to startup and immediately } \\
\text { following pump P-350 operations in accordance with manufacturer } \\
\text { recommendations. Additionally, this line-up can be used to add } \\
\text { dilution water to the convective waste in the tank through the } \\
\text { transfer pump inlet. }\end{array}$ \\
Pump P-350 Purge & $\begin{array}{l}\text { P-350 is de-energized / P-401 or P-402 is energized and running as } \\
\text { necessary to provide flush water pressure/flow rate as needed: } \\
\text { flush volume }=50 \text { gallons } \\
\text { - } 102^{\circ} \mathrm{F} \text { to } 130{ }^{\circ} \mathrm{F} \\
\text { flow rate is approximately } 10 \mathrm{gpm}\end{array}$ \\
\hline
\end{tabular}

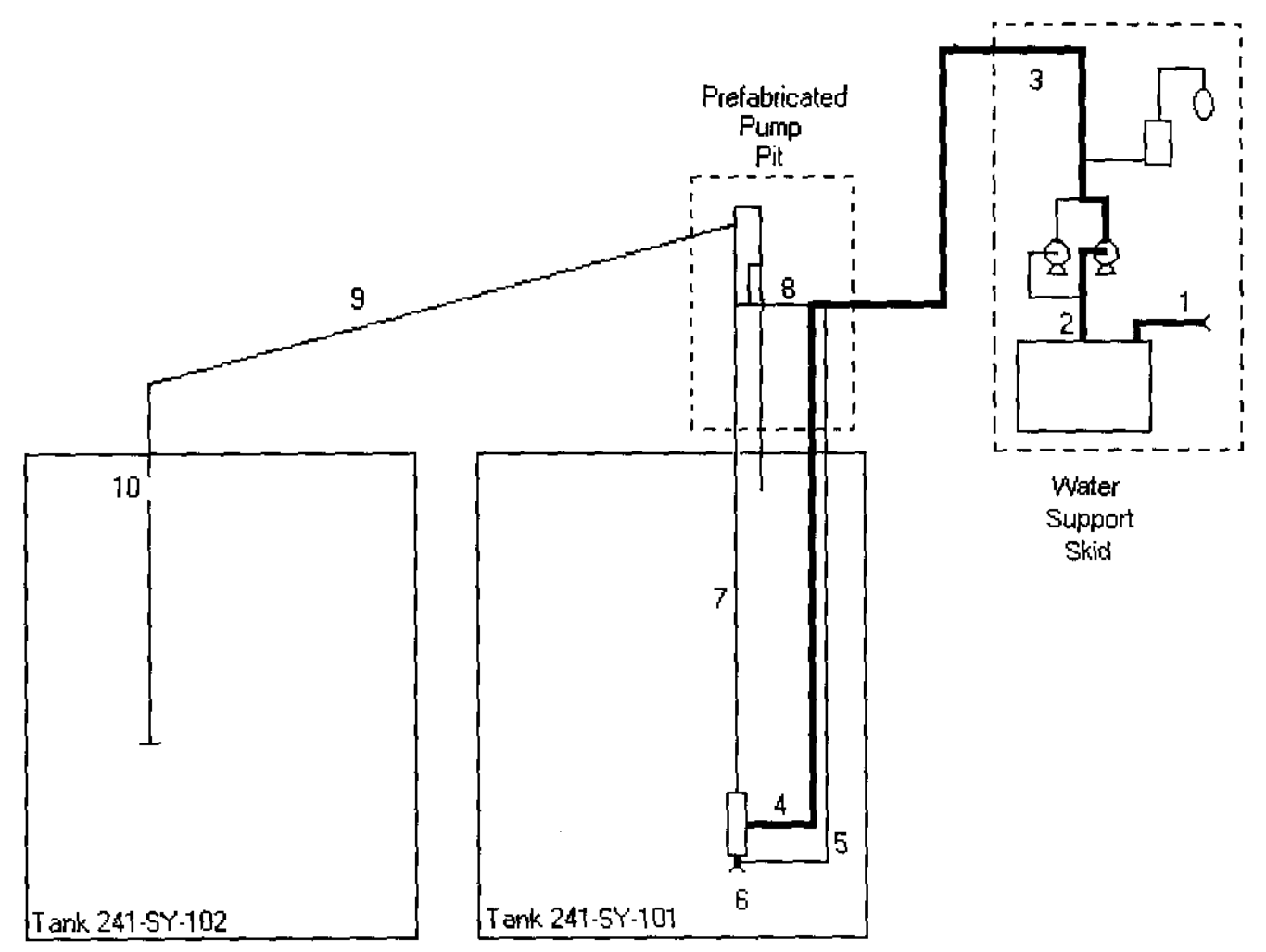


HNF-4264 REV. 2

Permissible Process Limits for Pump P-350 Purge

\begin{tabular}{|c|c|c|c|c|c|c|c|c|c|}
\hline $\begin{array}{c}\text { Flow } \\
\text { Parameter }\end{array}$ & $\begin{array}{l}\text { Water } \\
\text { Skid } \\
\text { Inlet } \\
\text { (1) }\end{array}$ & $\begin{array}{l}\text { Water } \\
\text { Skid } \\
\text { Outlet } \\
(2)\end{array}$ & $\begin{array}{c}\text { PPP } \\
\text { Water } \\
\text { Supply } \\
\text { Line } \\
(3)\end{array}$ & $\begin{array}{l}\text { Transfer } \\
\text { Pump } \\
\text { Internal } \\
\text { Flush } \\
\text { Line } \\
(4)\end{array}$ & $\begin{array}{c}\text { Transfer } \\
\text { Pump } \\
\text { Water } \\
\text { Supply } \\
\text { Line } \\
\text { (5) }\end{array}$ & $\begin{array}{l}\text { Transfer } \\
\text { Pump } \\
\text { Waste } \\
\text { Inlet } \\
(6)\end{array}$ & $\begin{array}{l}\text { Transfer } \\
\text { Pump } \\
\text { Outlet } \\
\text { (7) }\end{array}$ & $\begin{array}{l}\text { Flush } \\
\text { Cross- } \\
\text { Connect } \\
\text { (8) }\end{array}$ & $\begin{array}{l}\text { Transfer } \\
\text { Line } \\
(9)\end{array}$ \\
\hline Flow Rate & - & $\begin{array}{l}\sim 10 \\
\mathrm{gpm}\end{array}$ & $\begin{array}{l}\sim 10 \\
\mathrm{gpm}\end{array}$ & $\begin{array}{l}\sim 10 \\
\text { gpm }\end{array}$ & N/A & $\begin{array}{l}\sim 10 \\
\text { gpm }\end{array}$ & N/A & N/A & N/A \\
\hline $\begin{array}{c}\text { Flush } \\
\text { Volume }\end{array}$ & - & - & - & - & N/A & - & N/A & N/A & N/A \\
\hline $\begin{array}{c}\text { Flow } \\
\text { Velocity } \\
(\mathrm{tt} / \mathrm{sec})\end{array}$ & - & - & - & - & N/A & - & N/A & N/A & N/A \\
\hline $\begin{array}{l}\text { Temperature } \\
\left({ }^{\circ} \mathrm{F}\right)\end{array}$ & - & $\begin{array}{c}102 \\
\text { to } \\
130 \\
\end{array}$ & $\begin{array}{c}102 \\
\text { to } \\
130\end{array}$ & $\begin{array}{c}102 \\
\text { to } \\
130\end{array}$ & N/A & $\begin{array}{c}102 \\
\text { to } \\
130\end{array}$ & N/A & N/A & N/A \\
\hline $\begin{array}{l}\text { Viscosity } \\
\text { (cP) }\end{array}$ & - & $\begin{array}{c}0.50 \\
\text { to } \\
0.62 \\
\end{array}$ & $\begin{array}{c}0.50 \\
\text { to } \\
0.62\end{array}$ & $\begin{array}{c}0.50 \\
\text { to } \\
0.62\end{array}$ & N/A & $\begin{array}{c}0.50 \\
\text { to } \\
0.62\end{array}$ & N/A & N/A & N/A \\
\hline $\begin{array}{l}\text { Density } \\
(\text { grams } / c)\end{array}$ & $<1$ & $<1$ & $<1$ & $<1$ & N/A & $<1$ & $\mathrm{~N} / \mathrm{A}$ & N/A & N/A \\
\hline $\begin{array}{c}\text { Volume \% } \\
\text { Solids }\end{array}$ & $<0.01$ & $<0.01$ & $<0.01$ & $<0.01$ & N/A & $<0.01$ & $\mathrm{~N} / \mathrm{A}$ & $N / A$ & N/A \\
\hline $\begin{array}{c}\text { Mass \% } \\
\text { Water }\end{array}$ & 100 & 100 & 100 & 100 & N/A & 100 & N/A & N/A & N/A \\
\hline $\begin{array}{l}\text { Mass \% } \\
\text { Completely } \\
\text { Insoluble } \\
\text { Solids }\end{array}$ & 0 & 0 & 0 & 0 & N/A & 0 & N/A & N/A & N/A \\
\hline
\end{tabular}




\subsubsection{Siphon Break Flush}

\begin{tabular}{|l|l|l|}
\hline Process Flow Line-up & \multicolumn{1}{|c|}{ Line-up Notes and General Procedure } \\
\hline Vent Line Flush & $\begin{array}{l}\text { This line-up is used to clear the system vent line of potential } \\
\text { contamination with routing to tank } 241-S Y-102 \text { via the transfer line. } \\
\text { P } 350 \text { is de-energized / P-401 or P-402 is energized and running as } \\
\text { necessary to provide flush water pressure/flow rate as needed: } \\
-\quad 2 \times \text { line volumes or } 2 \text { minutes of flow, which-ever is greater } \\
-\quad 102^{\circ} \mathrm{F} \text { to } 130^{\circ} \mathrm{F} \\
\text { flow rate not to exceed } 70 \text { gpm } \\
\text { when possible, flush flow velocity should exceed } 4 \mathrm{ft} / \mathrm{sec}\end{array}$ \\
\hline
\end{tabular}

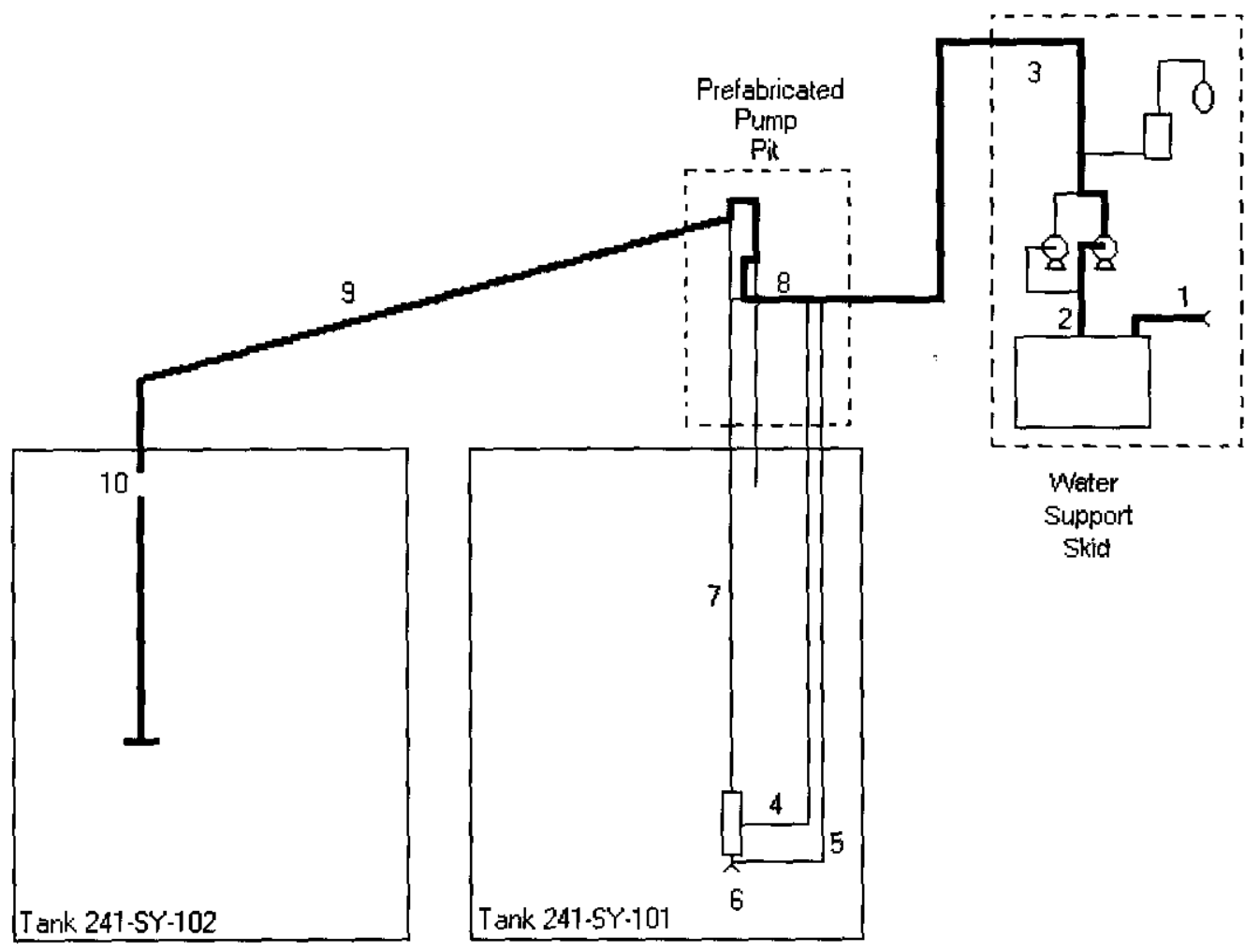


Permissible Process Limits for Siphon Break Flush

\begin{tabular}{|c|c|c|c|c|c|c|c|c|c|}
\hline $\begin{array}{c}\text { Flow } \\
\text { Parameter }\end{array}$ & $\begin{array}{l}\text { Water } \\
\text { Skid } \\
\text { Inlet } \\
(1)\end{array}$ & $\begin{array}{l}\text { Water } \\
\text { Skid } \\
\text { Outlet } \\
(2)\end{array}$ & $\begin{array}{l}\text { PPP } \\
\text { Water } \\
\text { Supply } \\
\text { Line } \\
\text { (3) }\end{array}$ & $\begin{array}{l}\text { Transfer } \\
\text { Pump } \\
\text { Internal } \\
\text { Flush } \\
\text { Line } \\
\text { (4) }\end{array}$ & $\begin{array}{l}\text { Transfer } \\
\text { Pump } \\
\text { Water } \\
\text { Supply } \\
\text { Line } \\
\text { (5) }\end{array}$ & $\begin{array}{c}\text { Transfer } \\
\text { Pump } \\
\text { Waste } \\
\text { Inlet } \\
(6)\end{array}$ & $\begin{array}{c}\text { Transfer } \\
\text { Pump } \\
\text { Outlet } \\
(7)\end{array}$ & $\begin{array}{l}\text { Flush } \\
\text { Cross- } \\
\text { Connect } \\
(8)\end{array}$ & $\begin{array}{l}\text { Transfer } \\
\text { Line } \\
(9)\end{array}$ \\
\hline $\begin{array}{l}\text { Flow } \\
\text { Rate }\end{array}$ & - & $\begin{array}{l}<70 \\
\text { gpm }\end{array}$ & $\begin{array}{l}<70 \\
\text { gpm }\end{array}$ & $\mathrm{N} / \mathrm{A}$ & N/A & N/A & N/A & $\begin{array}{l}<70 \\
\mathrm{gpm}\end{array}$ & $\begin{array}{l}<70 \\
\text { gpm }\end{array}$ \\
\hline $\begin{array}{l}\text { Flush } \\
\text { Volume }\end{array}$ & $\begin{array}{c}2 \text { line } \\
\text { volumes } \\
\text { or } 2 \\
\text { minutes } \\
\text { of flow, } \\
\text { which- } \\
\text { ever is } \\
\text { greater }\end{array}$ & $\begin{array}{c}2 \text { line } \\
\text { volumes } \\
\text { or } 2 \\
\text { minutes } \\
\text { of flow, } \\
\text { which- } \\
\text { ever is } \\
\text { greater }\end{array}$ & $\begin{array}{l}2 \text { line } \\
\text { volumes } \\
\text { or } 2 \\
\text { minutes } \\
\text { of flow, } \\
\text { which- } \\
\text { ever is } \\
\text { greater }\end{array}$ & N/A & N/A & N/A & N/A & $\begin{array}{c}2 \text { line } \\
\text { volumes } \\
\text { or } 2 \\
\text { minutes } \\
\text { of flow, } \\
\text { which- } \\
\text { ever is } \\
\text { greater }\end{array}$ & $\begin{array}{l}2 \text { line } \\
\text { volumes } \\
\text { or } 2 \\
\text { minutes } \\
\text { of flow, } \\
\text { which- } \\
\text { ever is } \\
\text { greater }\end{array}$ \\
\hline $\begin{array}{c}\text { Flow } \\
\text { Velocity } \\
(\mathrm{tt} / \mathrm{sec})\end{array}$ & - & - & - & N/A & N/A & N/A & N/A & 4 to 6 & 4 to 6 \\
\hline $\begin{array}{c}\text { Temperature } \\
\left({ }^{\circ} \mathrm{F}\right)\end{array}$ & - & $\begin{array}{c}102 \\
\text { to } \\
130\end{array}$ & $\begin{array}{c}102 \\
\text { to } \\
130\end{array}$ & N/A & N/A & N/A & N/A & $\begin{array}{c}102 \\
\text { to } \\
130\end{array}$ & $\begin{array}{c}102 \\
\text { to } \\
130\end{array}$ \\
\hline $\begin{array}{l}\text { Viscosity } \\
\text { (cP) }\end{array}$ & - & $\begin{array}{c}0.50 \\
\text { to } \\
0.62\end{array}$ & $\begin{array}{c}0.50 \\
\text { to } \\
0.62\end{array}$ & N/A & N/A & N/A & N/A & $\begin{array}{c}0.50 \\
\text { to } \\
0.62\end{array}$ & $\begin{array}{c}0.50 \\
\text { to } \\
0.62\end{array}$ \\
\hline $\begin{array}{l}\text { Density } \\
(\text { erams } / \mathrm{cc})\end{array}$ & $<1$ & $<1$ & $<1$ & N/A & N/A & N/A & N/A & $<1$ & $<1$ \\
\hline $\begin{array}{c}\text { Volume } \% \\
\text { Solids }\end{array}$ & $<0.01$ & $<0.01$ & $<0.01$ & N/A & N/A & N/A & N/A & $<0.01$ & $<0.01$ \\
\hline $\begin{array}{c}\text { Mass \% } \\
\text { Water }\end{array}$ & 100 & 100 & 100 & N/A & N/A & N/A & N/A & 100 & 100 \\
\hline $\begin{array}{l}\text { Mass \% } \\
\text { Completely } \\
\text { Insoluble } \\
\text { Solids }\end{array}$ & 0 & 0 & 0 & N/A & N/A & N/A & N/A & 0 & 0 \\
\hline
\end{tabular}




\subsubsection{ACC-401 Transfer Line Flush}

\begin{tabular}{|l|l|}
\hline \multicolumn{1}{|c|}{ Transfer System } & \multicolumn{1}{|c|}{ Process Flow Line-up Notes and General Procedure } \\
\hline & $\begin{array}{l}\text { This line-up is established immediately upon loss of electrical power, } \\
\text { or loss of dilution water supply. }\end{array}$ \\
Air-Powered & $\begin{array}{l}\text { Pumps P-350, P-401 and P-402 are de-energized } \\
\text { approximately } 90 \text { gallons from ACC-401 (i.e., the contents of } \\
\text { of ACC-401) is flushed in this direction } \\
102^{\circ} \mathrm{F} \text { to } 130^{\circ} \mathrm{F}\end{array}$ \\
\hline
\end{tabular}

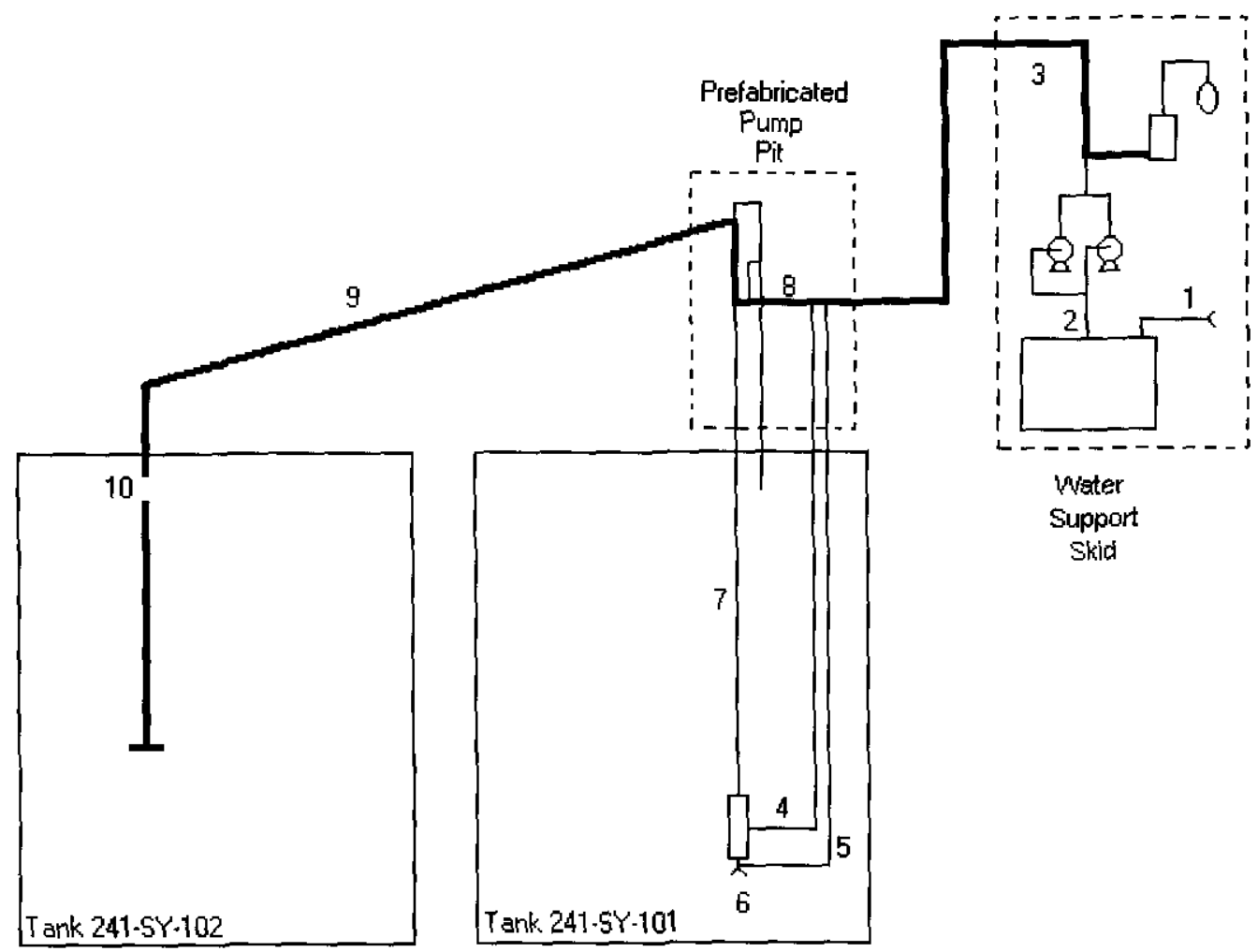


Permissible Process Limits for ACC-401 Transfer Line Flush

\begin{tabular}{|c|c|c|c|c|c|c|c|c|c|}
\hline $\begin{array}{c}\text { Flow } \\
\text { Parameter }\end{array}$ & $\begin{array}{l}\text { Water } \\
\text { Skid } \\
\text { Inlet } \\
(1)\end{array}$ & $\begin{array}{l}\text { Water } \\
\text { Skid } \\
\text { Outlet } \\
(2)\end{array}$ & $\begin{array}{c}\text { PPP } \\
\text { Water } \\
\text { Supply } \\
\text { Line } \\
(3)\end{array}$ & $\begin{array}{c}\text { Transfer } \\
\text { Pump } \\
\text { Internal } \\
\text { Flush } \\
\text { Line } \\
\text { (4) }\end{array}$ & $\begin{array}{l}\text { Transfer } \\
\text { Pump } \\
\text { Water } \\
\text { Supply } \\
\text { Line } \\
\text { (5) }\end{array}$ & $\begin{array}{l}\text { Transfer } \\
\text { Pump } \\
\text { Waste } \\
\text { Inlet } \\
\text { (6) }\end{array}$ & $\begin{array}{l}\text { Transfer } \\
\text { Pump } \\
\text { Outlet } \\
\text { (7) }\end{array}$ & $\begin{array}{c}\text { Flush } \\
\text { Cross- } \\
\text { Connect } \\
(8)\end{array}$ & $\begin{array}{l}\text { Transfer } \\
\text { Line } \\
(9)\end{array}$ \\
\hline $\begin{array}{l}\text { Flow } \\
\text { Rate }\end{array}$ & - & $\overline{\mathrm{N} / \mathrm{A}}$ & N/A & N/A & $\mathrm{N} / \mathrm{A}$ & $\overline{\mathrm{N} / \mathrm{A}}$ & N/A & N/A & N/A \\
\hline $\begin{array}{c}\text { Flush } \\
\text { Volume }\end{array}$ & $\begin{array}{c}2 \text { line } \\
\text { volumes } \\
\text { or } 2 \\
\text { minutes } \\
\text { of flow, } \\
\text { which- } \\
\text { ever is } \\
\text { greater }\end{array}$ & $\begin{array}{l}2 \text { line } \\
\text { volumes } \\
\text { or } 2 \\
\text { minutes } \\
\text { of flow, } \\
\text { which- } \\
\text { ever is } \\
\text { greater }\end{array}$ & $\begin{array}{c}2 \text { line } \\
\text { volumes } \\
\text { or } 2 \\
\text { minutes } \\
\text { of flow, } \\
\text { which- } \\
\text { ever is } \\
\text { greater }\end{array}$ & N/A & $\mathrm{N} / \mathrm{A}$ & N/A & N/A & $\begin{array}{l}2 \text { line } \\
\text { volumes } \\
\text { or } 2 \\
\text { minutes } \\
\text { of flow, } \\
\text { which- } \\
\text { ever is } \\
\text { greater }\end{array}$ & $\begin{array}{c}2 \text { line } \\
\text { volumes } \\
\text { or } 2 \\
\text { minutes } \\
\text { of flow, } \\
\text { which- } \\
\text { ever is } \\
\text { greater }\end{array}$ \\
\hline $\begin{array}{c}\text { Flow } \\
\text { Velocity } \\
(\mathrm{ft} / \mathrm{sec})\end{array}$ & - & - & - & N/A & N/A & N/A & N/A & 4 to 6 & 4 to 6 \\
\hline $\begin{array}{l}\text { Temperature } \\
\left({ }^{\circ} \mathrm{F}\right)\end{array}$ & - & $\begin{array}{c}102 \\
10 \\
130\end{array}$ & $\begin{array}{l}102 \\
\text { to } \\
130\end{array}$ & N/A & N/A & N/A & N/A & $\begin{array}{c}102 \\
\text { to } \\
130\end{array}$ & $\begin{array}{c}102 \\
\text { to } \\
130\end{array}$ \\
\hline $\begin{array}{c}\text { Viscosity } \\
\text { (cP) }\end{array}$ & - & $\begin{array}{c}0.50 \\
\text { to } \\
0.62\end{array}$ & $\begin{array}{c}0.50 \\
\text { to } \\
0.62\end{array}$ & N/A & N/A & N/A & N/A & $\begin{array}{c}0.50 \\
\text { to } \\
0.62\end{array}$ & $\begin{array}{c}0.50 \\
\text { to } \\
0.62\end{array}$ \\
\hline $\begin{array}{l}\text { Density } \\
(\text { grams } / \mathrm{cc})\end{array}$ & $<1$ & $<1$ & $<1$ & N/A & N/A & N/A & N/A & $<1$ & $<1$ \\
\hline $\begin{array}{c}\text { Volume \% } \\
\text { Solids }\end{array}$ & $<0.01$ & $<0.01$ & $<0.01$ & N/A & N/A & N/A & N/A & $<0.01$ & $<0.01$ \\
\hline $\begin{array}{c}\text { Mass \% } \\
\text { Water }\end{array}$ & 100 & 100 & 100 & N/A & N/A & N/A & N/A & 100 & 100 \\
\hline $\begin{array}{c}\text { Mass \% } \\
\text { Completely } \\
\text { Insoluble } \\
\text { Solids }\end{array}$ & 0 & 0 & 0 & N/A & N/A & N/A & N/A & 0 & 0 \\
\hline
\end{tabular}




\subsubsection{ACC-401 Transfer Line Back-Flush}

\begin{tabular}{|c|c|}
\hline $\begin{array}{l}\text { Transfer System } \\
\text { Process Flow Line-up }\end{array}$ & Line-up Notes and General Procedure \\
\hline $\begin{array}{l}\text { Air-Powered } \\
\text { Transfer Line Flush }\end{array}$ & $\begin{array}{l}\text { This line-up is established immediately upon loss of electrical power, } \\
\text { or loss of dilution water supply. } \\
\text { Pumps P-350, P-401 and P-402 are de-energized } \\
\text { - approximately } 90 \text { gallons from ACC-401 (i.e., the contents of } \\
\text { of ACC-401) is flushed in this direction } \\
\text { - } 102^{\circ} \mathrm{F} \text { to } 130^{\circ} \mathrm{F} \\
\text { - to be performed after the ACC-401 transfer line flush per } \\
\text { Section } 4.2 .6\end{array}$ \\
\hline
\end{tabular}

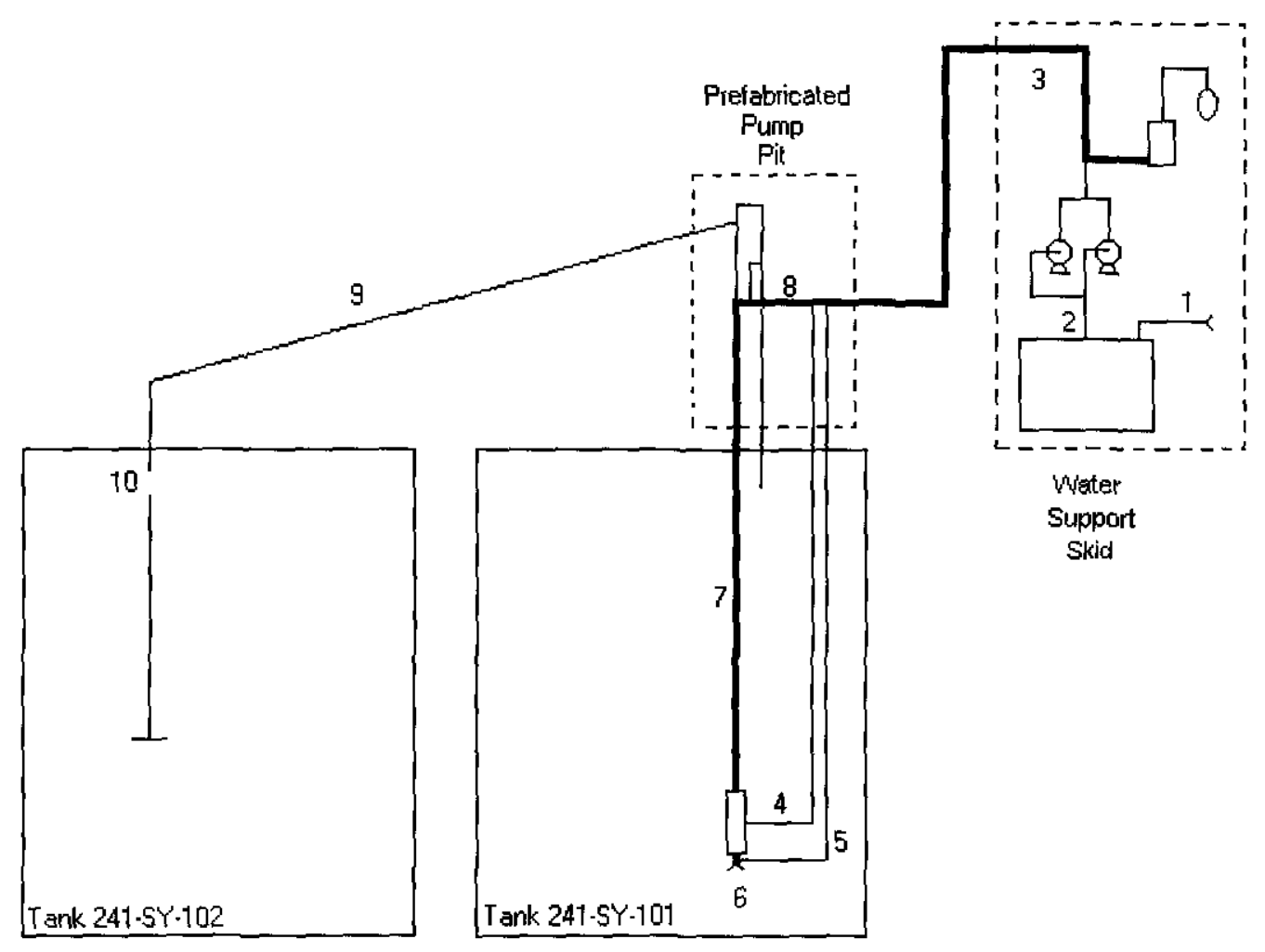


HNF-4264 REV. 2

Permissible Process Limits for ACC-401 Transfer Line Back-Flush

\begin{tabular}{|c|c|c|c|c|c|c|c|c|c|}
\hline $\begin{array}{c}\text { Flow } \\
\text { Parameter }\end{array}$ & $\begin{array}{l}\text { Water } \\
\text { Skid } \\
\text { Inlet } \\
(1)\end{array}$ & $\begin{array}{l}\text { Water } \\
\text { Skid } \\
\text { Outlet } \\
(2)\end{array}$ & $\begin{array}{l}\text { PPP } \\
\text { Water } \\
\text { Supply } \\
\text { Line } \\
\text { (3) }\end{array}$ & $\begin{array}{l}\text { Transfer } \\
\text { Pump } \\
\text { Internal } \\
\text { Flush } \\
\text { Line } \\
\text { (4) }\end{array}$ & $\begin{array}{l}\text { Transfer } \\
\text { Pump } \\
\text { Water } \\
\text { Supply } \\
\text { Line } \\
\text { (5) }\end{array}$ & $\begin{array}{c}\text { Transfer } \\
\text { Pump } \\
\text { Waste } \\
\text { Inlet } \\
(6)\end{array}$ & $\begin{array}{l}\text { Transfer } \\
\text { Pump } \\
\text { Outlet } \\
\text { (7) }\end{array}$ & $\begin{array}{l}\text { Flush } \\
\text { Cross- } \\
\text { Connect } \\
(8)\end{array}$ & $\begin{array}{c}\text { Transfer } \\
\text { Line } \\
(9)\end{array}$ \\
\hline Flow Rate & - & $\mathrm{N} / \mathrm{A}$ & $\mathrm{N} / \mathrm{A}$ & N/A & $\mathrm{N} / \mathrm{A}$ & $\mathrm{N} / \mathrm{A}$ & N/A & N/A & N/A \\
\hline $\begin{array}{l}\text { Flush } \\
\text { Volume }\end{array}$ & $\begin{array}{l}2 \text { line } \\
\text { volumes } \\
\text { or } 2 \\
\text { minutes } \\
\text { of flow, } \\
\text { which- } \\
\text { ever is } \\
\text { greater }\end{array}$ & $\begin{array}{l}2 \text { line } \\
\text { volumes } \\
\text { or } 2 \\
\text { minutes } \\
\text { of flow, } \\
\text { which- } \\
\text { ever is } \\
\text { greater }\end{array}$ & $\begin{array}{l}2 \text { line } \\
\text { volumes } \\
\text { or } 2 \\
\text { minutes } \\
\text { of flow, } \\
\text { which- } \\
\text { ever is } \\
\text { greater }\end{array}$ & N/A & N/A & $\begin{array}{l}2 \text { line } \\
\text { volumes } \\
\text { or } 2 \\
\text { minutes } \\
\text { of flow, } \\
\text { which- } \\
\text { ever is } \\
\text { greater }\end{array}$ & $\begin{array}{l}2 \text { line } \\
\text { volumes } \\
\text { or } 2 \\
\text { minutes } \\
\text { of flow, } \\
\text { which- } \\
\text { ever is } \\
\text { greater }\end{array}$ & $\begin{array}{c}2 \text { line } \\
\text { volumes } \\
\text { or } 2 \\
\text { minutes } \\
\text { of flow, } \\
\text { which- } \\
\text { ever is } \\
\text { greater }\end{array}$ & N/A \\
\hline $\begin{array}{c}\text { Flow } \\
\text { Velocity } \\
(\mathrm{t} / \mathrm{sec})\end{array}$ & - & - & - & N/A & N/A & - & 4 to 6 & 4 to 6 & N/A \\
\hline $\begin{array}{c}\text { Temperature } \\
\left({ }^{\circ} \mathrm{F}\right)\end{array}$ & - & $\begin{array}{c}102 \\
\text { to } \\
130\end{array}$ & $\begin{array}{c}102 \\
\text { to } \\
130\end{array}$ & N/A & N/A & $\begin{array}{c}102 \\
\text { to } \\
130\end{array}$ & $\begin{array}{c}102 \\
\text { to } \\
130\end{array}$ & $\begin{array}{c}102 \\
\text { to } \\
130\end{array}$ & N/A \\
\hline $\begin{array}{l}\text { Viscosity } \\
\text { (cP) }\end{array}$ & - & $\begin{array}{c}0.50 \\
\text { to } \\
0.62\end{array}$ & $\begin{array}{c}0.50 \\
\text { to } \\
0.62\end{array}$ & N/A & N/A & $\begin{array}{c}0.50 \\
\text { to } \\
0.62\end{array}$ & $\begin{array}{c}0.50 \\
\text { to } \\
0.62\end{array}$ & $\begin{array}{c}0.50 \\
\text { to } \\
0.62\end{array}$ & N/A \\
\hline $\begin{array}{l}\text { Density } \\
(\text { grans } / \mathrm{co})\end{array}$ & $<1$ & $<1$ & $<1$ & N/A & N/A & $<1$ & $<1$ & $<1$ & N/A \\
\hline $\begin{array}{l}\text { Volume \% } \\
\text { Solids }\end{array}$ & $<0.01$ & $<0.01$ & $<0.01$ & N/A & N/A & $<0.01$ & $<0.01$ & $<0.01$ & N/A \\
\hline $\begin{array}{c}\text { Mass \% } \\
\text { Water }\end{array}$ & 100 & 100 & 100 & N/A & N/A & 100 & 100 & 100 & N/A \\
\hline $\begin{array}{c}\text { Mass \% } \\
\text { Completely } \\
\text { Insoluble } \\
\text { Solids }\end{array}$ & 0 & 0 & 0 & N/A & N/A & 0 & 0 & 0 & N/A \\
\hline
\end{tabular}




\subsubsection{Waste Transfer}

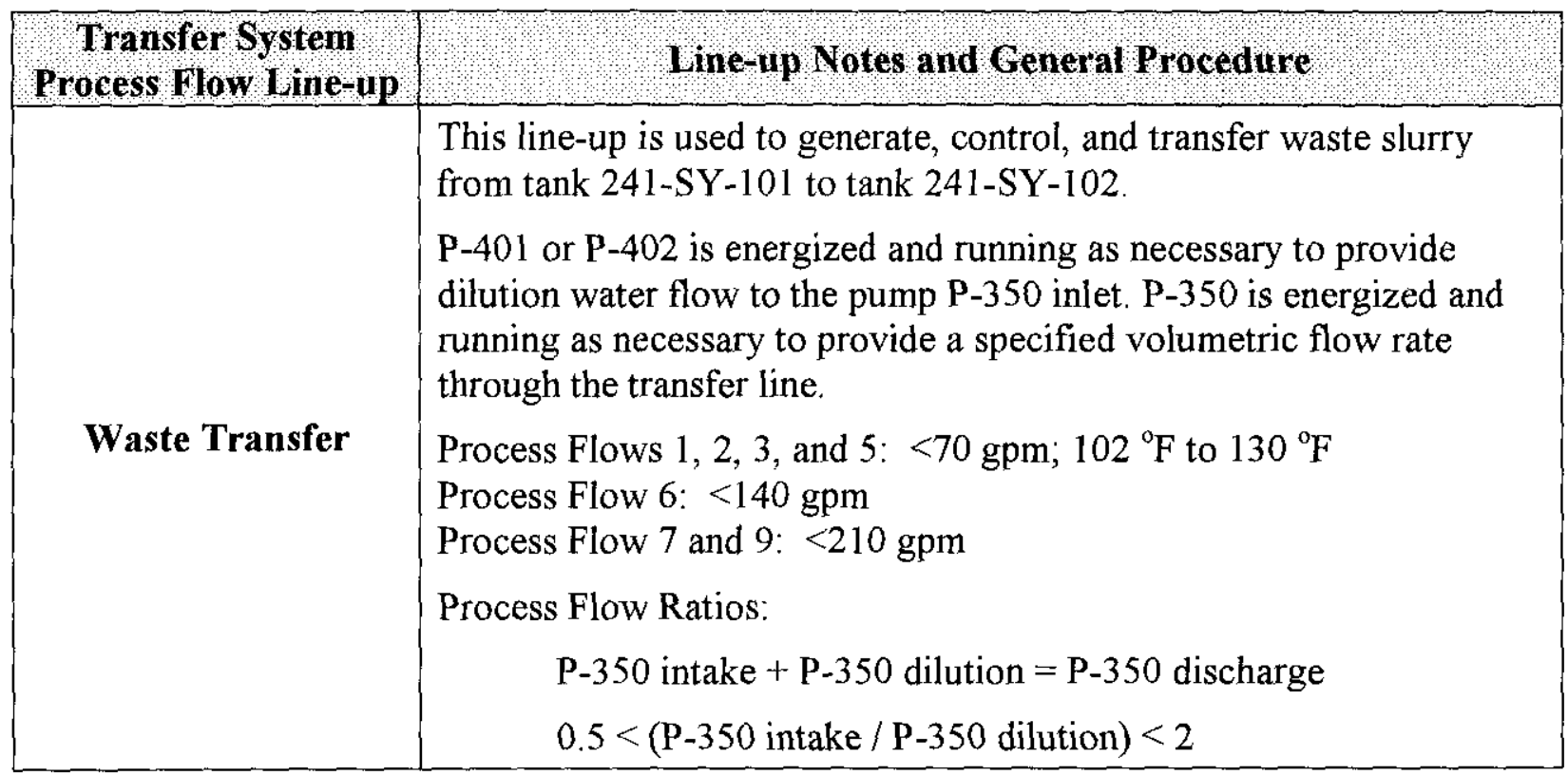

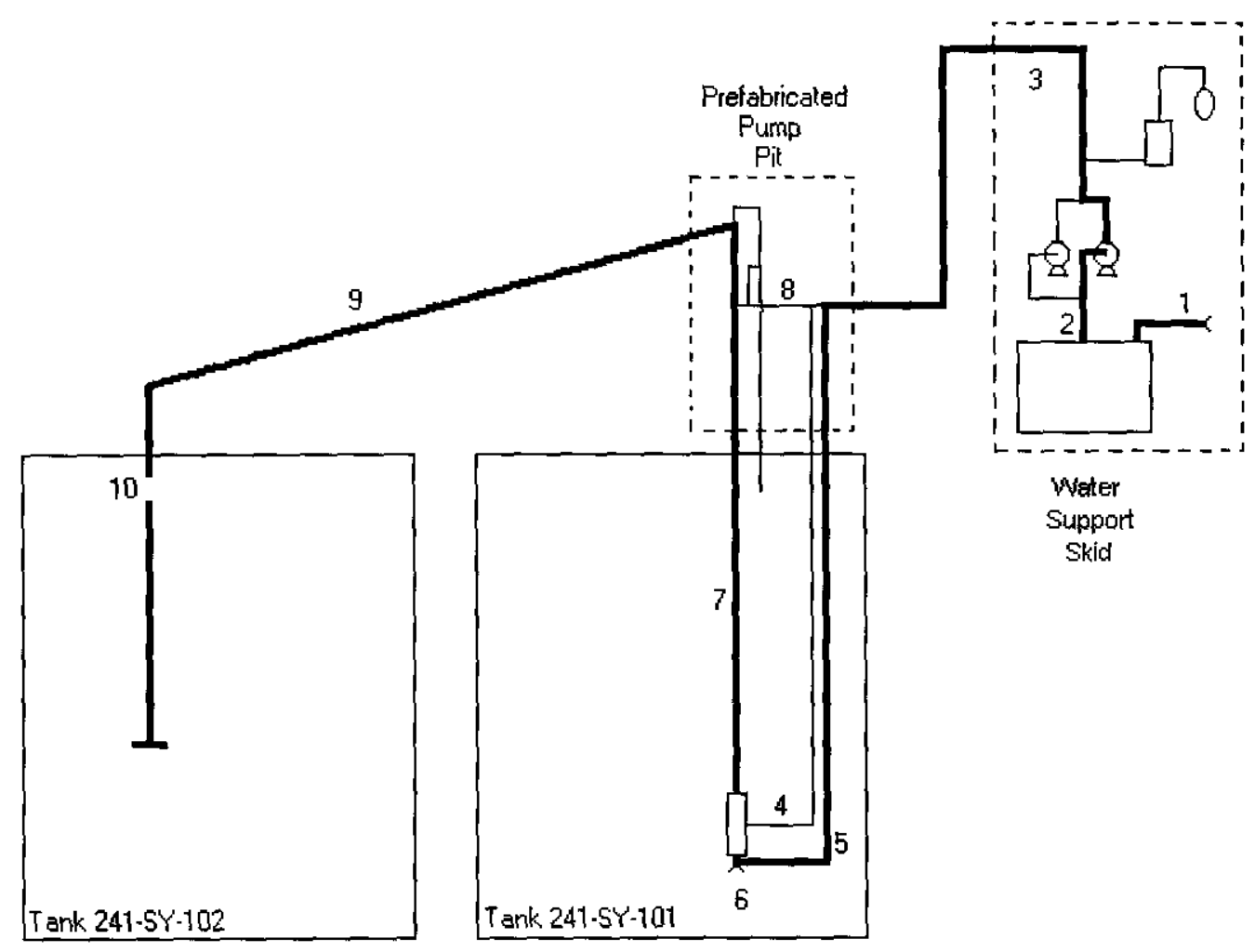


Table 4-2. Permissible Process Limits for Waste Transfer

\begin{tabular}{|c|c|c|c|}
\hline $\begin{array}{l}\text { Fluid/Flow } \\
\text { Parameter }\end{array}$ & $\begin{array}{c}\text { Pump P-350 Dilution } \\
\text { Water Flow }\end{array}$ & $\begin{array}{c}\text { Pump P-350 Waste } \\
\text { Inlet }\end{array}$ & $\begin{array}{c}\text { Pump P-350 } \\
\text { Discharge; } \\
\text { Transfer Line }\end{array}$ \\
\hline Flow Rate & $\begin{array}{c}1 / 3 \mathrm{R} \text { to } 2 / 3 \mathrm{R} \\
\text { not to exceed } \\
70 \mathrm{gpm}\end{array}$ & ${ }^{1} / 3 \mathrm{R}$ to $2 / 3 \mathrm{R}$ & 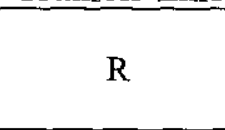 \\
\hline Flow Velocity $(\mathrm{t} / \mathrm{sec})$ & - & - & $\geq 6$ \\
\hline Temperature $\left({ }^{\circ} \mathrm{F}\right)$ & 102 to 130 & - & - \\
\hline Viscosity (cP) & 0.50 to 0.62 & 50 to 200 & 2 to 15 \\
\hline Density $($ gams/co $)$ & $<1$ & 1.45 to 1.75 & 1.16 to 1.50 \\
\hline $\begin{array}{c}\text { Mass } \% \\
\text { Non-Soluble } \\
\text { Solids } \\
\end{array}$ & 0 & 1 to 3 & 0 to 2 \\
\hline Volume \% Solids & $<0.01$ & 5 to 25 & 2 to 17 \\
\hline Mass \% Water & 100 & 27.8 to 46.2 & 40 to 81 \\
\hline Mass \% Sodium & 0 & 14.2 to 23.8 & 7 to 17 \\
\hline Mass $\%$ Nitrate & 0 & 8.2 to 13.8 & 4 to 10 \\
\hline Mass $\%$ Nitrite & 0 & 8.2 to 13.8 & 4 to 10 \\
\hline Mass $\%$ Hydroxide & 0 & 4 to 12 & 2 to 9 \\
\hline Mass $\%$ Carbonate & 0 & 2 to 6 & 1 to 4 \\
\hline Mass \% Aluminum & 0 & 1.5 to 4.5 & 0 to 3 \\
\hline $\begin{array}{c}\text { Mass \% } \\
\text { Chloride }+ \text { Sulfate }+ \\
\text { Phosphate }\end{array}$ & 0 & 1 to 3 & 0 to 2 \\
\hline Mass \% TOC & 0 & 0 to 2 & 0 to 1 \\
\hline $\begin{array}{c}\text { Mass } \% \\
\text { Other } \\
\text { Constituents }\end{array}$ & 0 & 2 to 6 & 1 to 4 \\
\hline
\end{tabular}

$$
\mathrm{R}=\text { transfer flow rate }
$$




\subsubsection{Tank Water Addition via Transfer Pump Dilution Line}

\begin{tabular}{|c|c|}
\hline $\begin{array}{l}\text { Transfer System } \\
\text { Process Mlow Line-up }\end{array}$ & Line-up Notes and General Procedure \\
\hline $\begin{array}{l}\text { Tank Water Addition } \\
\text { Through Vent Line }\end{array}$ & $\begin{array}{l}\text { This line-up is used to supply tank back-dilution water to the } \\
\text { convective waste using the normal dilution water supply line to } \\
\text { pump P-350. } \\
\text { P-350 is de-energized / P-401 or P-402 is energized and running as } \\
\text { necessary to provide flush water pressure/flow rate as needed: } \\
\text { - } 102^{\circ} \mathrm{F} \text { to } 130^{\circ} \mathrm{F} \\
\text { - flow rate not to exceed } 70 \mathrm{gpm}\end{array}$ \\
\hline
\end{tabular}

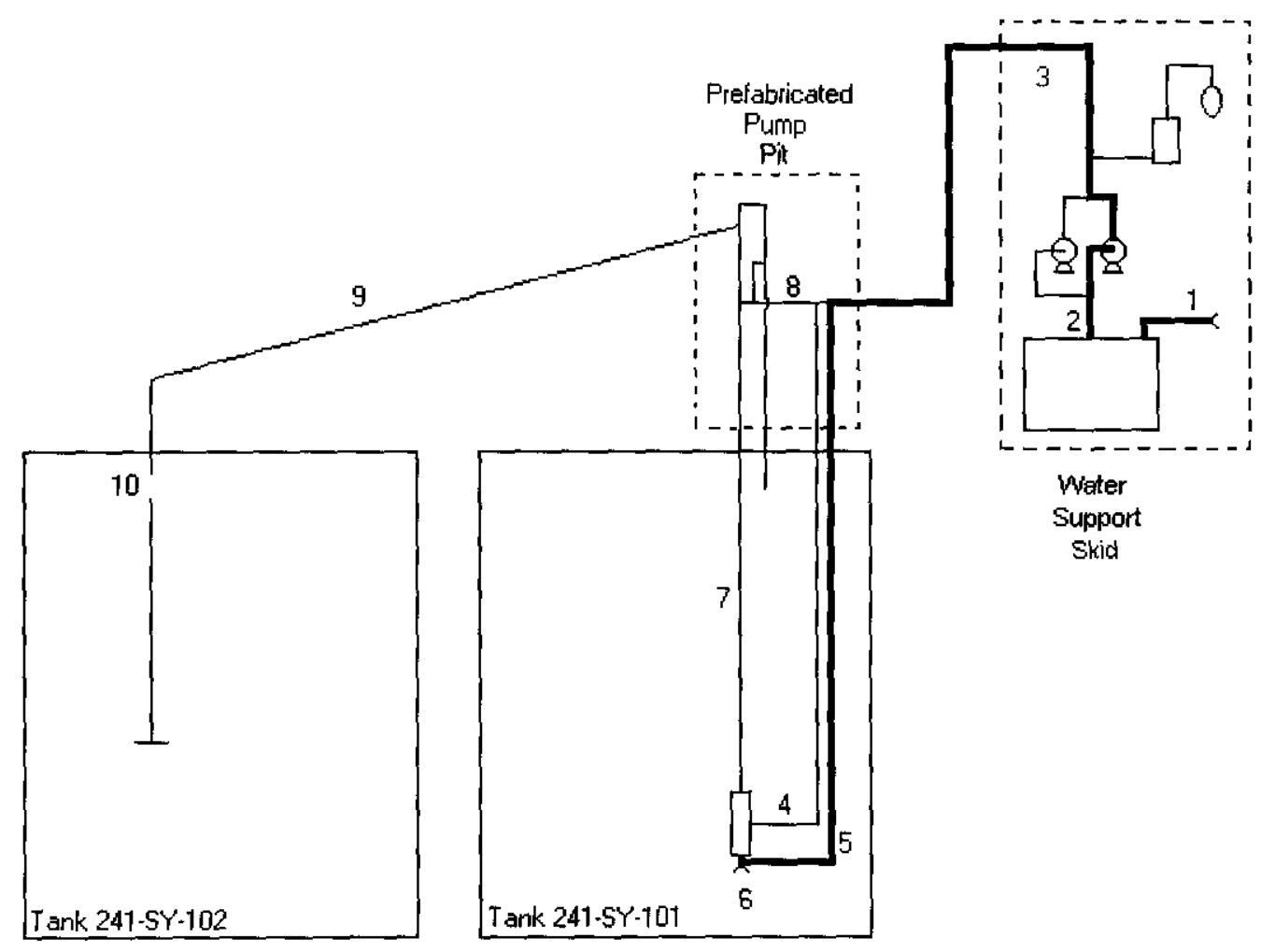


HNF-4264 REV. 2

Permissible Process Limits for

Tank Water Addition via Transfer Pump Dilution Line

\begin{tabular}{|c|c|c|c|c|c|c|c|c|c|}
\hline $\begin{array}{c}\text { Flow } \\
\text { Parameter }\end{array}$ & $\begin{array}{l}\text { Water } \\
\text { Skid } \\
\text { Inlet } \\
\text { (1) }\end{array}$ & $\begin{array}{l}\text { Water } \\
\text { Skid } \\
\text { Outlet } \\
(2)\end{array}$ & $\begin{array}{l}\text { PPP } \\
\text { Water } \\
\text { Supply } \\
\text { Line } \\
\text { (3) }\end{array}$ & $\begin{array}{l}\text { Transfer } \\
\text { Pump } \\
\text { Internal } \\
\text { Flush } \\
\text { Line } \\
(4)\end{array}$ & $\begin{array}{l}\text { Transfer } \\
\text { Pump } \\
\text { Water } \\
\text { Supply } \\
\text { Line } \\
\text { (5) }\end{array}$ & $\begin{array}{l}\text { Transfer } \\
\text { Pump } \\
\text { Waste } \\
\text { Inlet } \\
(6)\end{array}$ & $\begin{array}{l}\text { Transfer } \\
\text { Pump } \\
\text { Outlet } \\
(7)\end{array}$ & $\begin{array}{l}\text { Flush } \\
\text { Cross- } \\
\text { Connect } \\
(8)\end{array}$ & $\begin{array}{l}\text { Transfer } \\
\text { Line } \\
\text { (9) }\end{array}$ \\
\hline $\begin{array}{l}\text { Flow } \\
\text { Rate }\end{array}$ & - & $\begin{array}{l}<70 \\
\mathrm{gpm}\end{array}$ & $\begin{array}{l}<70 \\
\mathrm{gpm}\end{array}$ & $\mathrm{N} / \mathrm{A}$ & $\begin{array}{l}<70 \\
\mathrm{gpm}\end{array}$ & N/A & N/A & N/A & N/A \\
\hline $\begin{array}{c}\text { Flush } \\
\text { Volume }\end{array}$ & & $\begin{array}{c}\text { See } \\
\text { process } \\
\text { memo }\end{array}$ & $\begin{array}{c}\text { See } \\
\text { process } \\
\text { memo }\end{array}$ & N/A & $\begin{array}{c}\text { See } \\
\text { process } \\
\text { memo }\end{array}$ & N/A & N/A & N/A & N/A \\
\hline $\begin{array}{c}\text { Flow } \\
\text { Velocity } \\
(\mathrm{t} / \mathrm{sec})\end{array}$ & - & - & - & N/A & - & N/A & N/A & N/A & N/A \\
\hline $\begin{array}{l}\text { Temperature } \\
\left({ }^{\circ} \mathrm{F}\right)\end{array}$ & - & $\begin{array}{c}102 \\
\text { to } \\
130 \\
\end{array}$ & $\begin{array}{c}102 \\
\text { to } \\
130\end{array}$ & N/A & $\begin{array}{c}102 \\
\text { to } \\
130\end{array}$ & N/A & N/A & N/A & N/A \\
\hline $\begin{array}{c}\text { Viscosity } \\
\text { (cP) }\end{array}$ & - & $\begin{array}{c}0.50 \\
\text { to } \\
0.62\end{array}$ & $\begin{array}{c}0.50 \\
\text { to } \\
0.62\end{array}$ & N/A & $\begin{array}{c}0.50 \\
\text { to } \\
0.62\end{array}$ & N/A & N/A & N/A & N/A \\
\hline $\begin{array}{l}\text { Density } \\
\text { (rrans/cc) }\end{array}$ & $<1$ & $<1$ & $<1$ & N/A & $<1$ & N/A & N/A & N/A & N/A \\
\hline $\begin{array}{l}\text { Volume \% } \\
\text { Solids }\end{array}$ & $<0.01$ & $\leq 0.01$ & $<0.01$ & N/A & $<0.01$ & N/A & N/A & $\mathrm{N} / \mathrm{A}$ & $\mathrm{N} / \mathrm{A}$ \\
\hline $\begin{array}{c}\text { Mass \% } \\
\text { Water }\end{array}$ & 100 & 100 & 100 & N/A & 100 & N/A & N/A & N/A & N/A \\
\hline $\begin{array}{c}\text { Mass \% } \\
\text { Completely } \\
\text { Insoluble } \\
\text { Solids } \\
\end{array}$ & 0 & 0 & 0 & N/A & 0 & N/A & N/A & N/A & N/A \\
\hline
\end{tabular}




\subsubsection{Tank Water Addition via Transfer System Vent Line}

\begin{tabular}{|l|l|l|}
\hline Process Flow Line-up & \multicolumn{1}{|c|}{ Tine-up Notes and General Procedure } \\
\hline & $\begin{array}{l}\text { This line-up is used to supply tank back-dilution water directly to } \\
\text { the top of the crust. } \\
\text { P-350 is de-energized / P-401 or P-402 is energized and running as } \\
\text { Tecessary to provide flush water pressure/flow rate as needed: }\end{array}$ \\
Through Vent Line & $\begin{array}{l}\text { Water temperature for tank back-dilution water added } \\
\text { directly to the top of the crust must be less than } 130^{\circ} \mathrm{F} . \\
\text { flow rate not to exceed } 70 \text { gpm (since the vent line is } 1 \text { inch } \\
\text { ID, actual water addition rate may be significantly less than } \\
\text { this value). }\end{array}$ \\
\hline
\end{tabular}

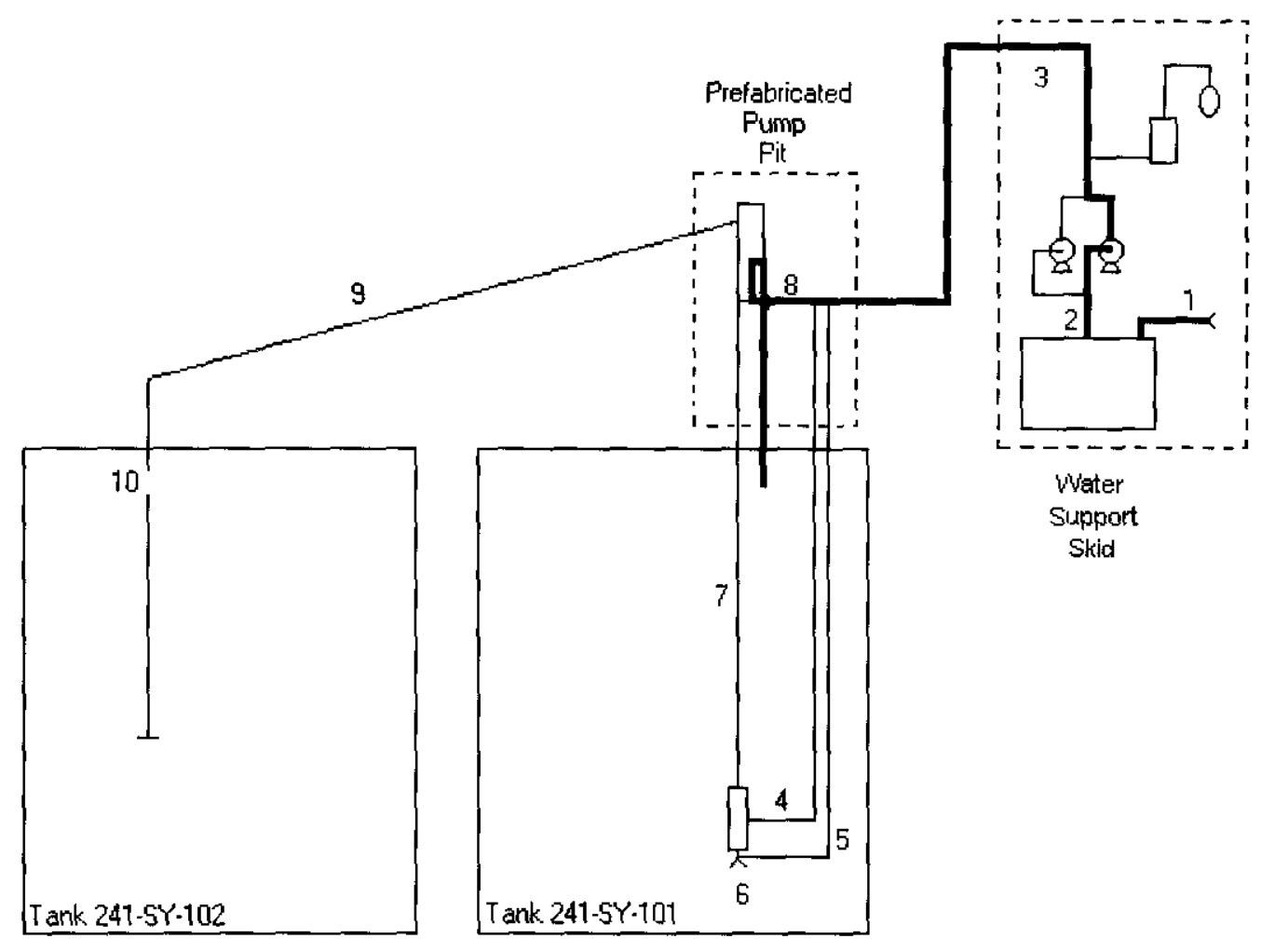


Permissible Process Limits for

Tank Water Addition via Transfer System Vent Line

\begin{tabular}{|c|c|c|c|c|c|c|c|c|c|}
\hline $\begin{array}{c}\text { Flow } \\
\text { Parameter }\end{array}$ & $\begin{array}{l}\text { Water } \\
\text { Skid } \\
\text { Inlet } \\
(1)\end{array}$ & $\begin{array}{l}\text { Water } \\
\text { Skid } \\
\text { Outlet } \\
(2)\end{array}$ & $\begin{array}{l}\text { PPP } \\
\text { Water } \\
\text { Supply } \\
\text { Line } \\
(3)\end{array}$ & $\begin{array}{c}\text { Transfer } \\
\text { Pump } \\
\text { Internal } \\
\text { Flush } \\
\text { Line } \\
(4) \\
\end{array}$ & $\begin{array}{c}\text { Transfer } \\
\text { Pump } \\
\text { Water } \\
\text { Supply } \\
\text { Line } \\
\text { (5) } \\
\end{array}$ & $\begin{array}{l}\text { Transfer } \\
\text { Pump } \\
\text { Waste } \\
\text { Inlet } \\
(6)\end{array}$ & $\begin{array}{l}\text { Transfer } \\
\text { Pump } \\
\text { Outlet } \\
(7)\end{array}$ & $\begin{array}{l}\text { Flush } \\
\text { Cross- } \\
\text { Connect } \\
\text { (8) }\end{array}$ & $\begin{array}{l}\text { Transfer } \\
\text { Line } \\
(9)\end{array}$ \\
\hline $\begin{array}{l}\text { Flow } \\
\text { Rate }\end{array}$ & - & $\begin{array}{l}<70 \\
\text { gpm } \\
\end{array}$ & $\begin{array}{l}<70 \\
\mathrm{gpm} \\
\end{array}$ & N/A & N/A & N/A & N/A & $\begin{array}{l}<70 \\
\mathrm{gpm}\end{array}$ & N/A \\
\hline $\begin{array}{l}\text { Flush } \\
\text { Volume }\end{array}$ & & $\begin{array}{c}\text { See } \\
\text { process } \\
\text { memo }\end{array}$ & $\begin{array}{l}\text { See } \\
\text { process } \\
\text { memo }\end{array}$ & N/A & N/A & N/A & N/A & $\begin{array}{c}\text { See } \\
\text { process } \\
\text { memo }\end{array}$ & $\mathrm{N} / \mathrm{A}$ \\
\hline $\begin{array}{c}\text { Flow } \\
\text { Velocity } \\
(\mathrm{t} / \mathrm{sec})\end{array}$ & - & - & - & N/A & N/A & N/A & N/A & - & N/A \\
\hline $\begin{array}{c}\text { Temperature } \\
\left({ }^{\circ} \mathrm{F}\right)\end{array}$ & - & $\begin{array}{c}102 \\
\text { to } \\
130\end{array}$ & $\begin{array}{c}102 \\
\text { to } \\
130 \\
\end{array}$ & N/A & N/A & N/A & N/A & $\begin{array}{c}102 \\
\text { to } \\
130 \\
\end{array}$ & N/A \\
\hline $\begin{array}{l}\text { Viscosity } \\
\text { (cP) }\end{array}$ & - & $\begin{array}{c}0.50 \\
\text { to } \\
0.62\end{array}$ & $\begin{array}{c}0.50 \\
\text { to } \\
0.62\end{array}$ & $\mathrm{~N} / \mathrm{A}$ & N/A & N/A & N/A & $\begin{array}{c}0.50 \\
\text { to } \\
0.62\end{array}$ & N/A \\
\hline $\begin{array}{l}\text { Density } \\
(\text { gensa } / \mathrm{cc})\end{array}$ & $<1$ & $<1$ & $<1$ & N/A & N/A & N/A & N/A & $<1$ & N/A \\
\hline $\begin{array}{l}\text { Volume \% } \\
\text { Solids }\end{array}$ & $<0.01$ & $<0.01$ & $<0.01$ & N/A & N/A & N/A & N/A & $<0.01$ & N/A \\
\hline $\begin{array}{c}\text { Mass } \% \\
\text { Water }\end{array}$ & 100 & 100 & 100 & N/A & N/A & N/A & N/A & 100 & N/A \\
\hline $\begin{array}{l}\text { Mass \% } \\
\text { Completely } \\
\text { Insoluble } \\
\text { Solids }\end{array}$ & 0 & 0 & 0 & N/A & N/A & N/A & N/A & 0 & N/A \\
\hline
\end{tabular}




\subsection{CONTRACTOR PRUDENT CONTROLS IMPLEMENTED BY THIS PROCESS CONTROL PLAN}

The Authorization Basis for waste transfers from tank 241-SY-101 to tank 241-SY-102 via the RAPID waste transfer system is unique, involving a DOE approved Unreviewed Safety Question (TF-97-0975, Rev. 3), and DOE directed safety requirements (Wagoner 1998 and French 1999). In addition, the requirements of the FSAR (LMHC 1999b) and TSRs (LMHC 1999c) are applicable. The basis for contractor prudent controls are described in HNF-3737, Tank 241-SY-101 Safety Basis for Remediation Actions and Operations Before Closure of the Unreviewed Safety Question on Waste Surface Change (LMHC 1999d). Of special note is the DOE directed requirement (French 1999) for the Contractor to impose prudent controls necessary to safely operate. These Contractor imposed prudent controls necessary to safely operate are approved by the River Protection Project Plant Review Committee (PRC) and documented in HNF-IP-1266, Tank Farms Operations Administrative Controls.

To be implemented properly, several Authorization Basis requirements and Contractor imposed prudent controls require that additional process control related details be provided. These details are provided in this chapter. In any instance where there is a conflict between the Authorization Basis requirements or Contractor imposed prudent controls described in the references above, and requirements in this process control plan, the above references take precedence. 


\subsection{IMPLEMENTATION OF TSR AC5.12.b, MATERIAL BALANCE REQUIREMENTS}

Waste transfer material balances are required to detect transfer system leaks as a back up to the transfer system leak detectors located in the PPP and in the ASSD enclosure. TSR AC5.12.b specifies the Authorization Basis requirements, which are implemented as follows:

\section{HNF-IP-1266, 5.12.3.C.3.C}

The following actions shall be performed 30 minutes and 60 minutes after initiation of the waste transfer and each 2 hours thereafter until the transfer is complete.

NOTE: Material balance monitoring criteria based on planned waste transfer rates shall be identified in the specific transfer procedures.

1. Perform material balance calculations to provide early leak detection and avoid filling tanks above safe levels.

A. If periodic material balance calculations indicate a variance that exceeds the criteria, the transfer shall be stopped.

Waste tank level indication is typically used as the input for the material balance calculation. However, because of crust gas retention and growth in tank 241-SY-101, the waste level indicator in tank 241-SY-101 may not measure the volume of material (waste and dilution water) transferred out of tank 241-SY-101 accurately. The material balance calculation for waste transfer from tank 241-SY-101 to tank 241-SY-102 via the RAPID waste transfer system, therefore, is performed in a unique manner, utilizing the waste level indicator in tank 241-SY-102 and the waste transfer flow totalizer (FQIT-367). These instruments shall meet the requirements of TSR AC5.19, "Process Instrumentation and Measuring and Test Equipment," for the purpose of satisfying this control. The material balance must comply with Table 5-1:

Table 5-1. Material Balance for Leak Detection

\begin{tabular}{|c|c|}
\hline Time of Material Balance Measurement & $\begin{array}{c}\text { Volumetric Discrepancy } \\
\text { (241-SY-102 current }-241-S Y-102 \text { initial }) \\
\text { waste level x 2,750-FQIT-367 }\end{array}$ \\
\hline 30 minutes & $\leq 1400$ gallons \\
\hline 60 minutes & $\leq 1400$ gallons \\
\hline$(1+2 n)$ hours $\mathrm{n}=1,2,3, \ldots$ & $\leq 2000$ gallons \\
\hline
\end{tabular}




\section{Material Balance Monitoring Criteria}

If the volumetric discrepancies of Table 5-1 are exceeded, the following inspections must occur: The leak detector annunciators and transfer line must be visually inspected concurrently with the material balance frequency of Table 5-1. Stop transfer if these inspections show evidence of a leak. If these inspections show no evidence of a leak, the waste transfer can continue.

In order to perform this material balance within the constraints imposed by saltwell pumping, either of the following options must be used:

1) Saltwell pumping must be suspended during tank 241-SY-101 waste transfer operations.

2) An acceptable method must be devised to preserve the capability of tank 241-SY-102 level to serve as a material balance measurement for the tank 241-SY-101 waste transfer. 


\subsection{ALLOWABLE VOLUME OF WASTE TRANSFERRED OUT OF TANK 241-SY-101}

In order to maintain the necessary operational performance of the mixer pump in light of possible encroachment of the crust on the mixer pump suction, the waste conditions must be maintained in a condition such that water addition to the convective waste must be capable of raising the bottom of the crust to a 295 inch level. This level is specified as the lowest crust level at which acceptable mixer pump operation has been demonstrated to date. Controls to ensure this are specified as Contractor imposed prudent controls necessary to safely operate as follows:

\section{HNF-IP-1266, 5.12.3.C.2.0}

The maximum volume of WASTE that can be transferred from Tank 241-SY-101 shall not exceed 96,000 gallons (Barton 1999). The RAPID Mitigation Sytem shall be placed under administrative lock in accordance with Chapter 5.20 within 8 hours following the transfer of the maximum volume of WASTE.

\section{HNF-IP-1266, 5.12.3.C.3.j}

WASTE transfers from 241-SY-101 shall be monitored to ensure that the maximum volume of WASTE approved for transfer is not exceeded (see requirement 5.12.3.C.2.o on page 6).

The waste transfer from 241-SY-101 shall be monitored using the transfer line flow meter (SY101-WT-FQIT-367) and dilution water flow totalizer (POR32-RW-FQIT-419). These instruments are designated as safety-class SSCs. The waste transfer must be stopped in time to satisfy the following equation:

$\mathrm{A}-\mathrm{B}<\mathrm{C}$

Where

$\mathrm{A}=$ volume change as indicated transfer line flow meter (SY101-WT-FQIT-367)

$\mathrm{B}=$ volume indicated by totalized flow from FQIT-419

$\mathrm{C}=96,000$ gallons

Additionally, the total volume of waste must include allowance for the volume that may be siphoned in the time period between shutdown of the transfer pump and the establishment of the Administrative Lock on the system As discussed in Section 6.6, the RAPID transfer system operating procedure must explicitly require the time at which the status of pump P-350 and valves V-362 and V-351 is changed to be recorded. 


\subsection{ALLOWABLE VOLUME OF TANK 241-SY-101 DILUTION}

In order to provide maximum confidence for mixer pump operability following tank back-dilution activities, it has been determined that the crust in the tank should not sink prior to its properties being sufficiently altered so that mixer pump operation will not be significantly impeded. The bulk density of the crust in the preexisting condition is estimated to be on the order of $1.4 \mathrm{gm} / \mathrm{cc}$ whereas the convective waste density is on the order of $1.6 \mathrm{gm} / \mathrm{cc}$. The objective is to prevent the convective waste from decreasing below the bulk crust density until such time as such an action is desired and the safety basis adequately describes the event. This requirement is implemented as a Contractor Prudent Control as follows:

\section{HNF-IP-1266, 5.9.3.C}

1.b) The TRG shall identify mixer pump operating parameters (e.g., pump motor current, pump discharge pressure), and shall establish limits for the selected parameters to prevent pump damage. These operating parameters shall be monitored during mixer pump operation, and the mixer pump shall be shut down if the established limits are exceeded.

1.c) the mixer pump performance parameters (e.g., pump motor current, pump discharge pressure, waste thermocouple response), and shall be monitored and the TRG shall review the data quarterly for signs of degradation that could affect continued control of gas retention at depth and prevention of buoyant displacement gas release events.

1.d) The TRG shall direct corrective actions to restore mixer pump operation and performance, as necessary.

1.e) Back dilution of the Tank 241-SY-101 WASTE with water following the transfer of waste from the tank shall be limited and controlled in accordance with A through $\mathrm{C}$ below.

A. The maximum volume of back dilution water that can be added on top of the crust is 30,000 gallons (Barton 1999).

B. The maximum volume of back dilution water that can be added low in the tank (via the 241-SY-101 mixer pump burrowing ring or the WASTE transfer pump) is 72,000 gallons (Barton 1999).

C. Back dilution water additions to Tank 241-SY-101 shall be monitored and limited to the maximum allowable volumes as specified in A and B above. 
The following notes apply to initial tank back-dilution:

1. Water addition to the convective waste is at an elevation of 96 inches when added via the transfer pump P-350.

2. Water addition to the convective waste is at an elevation of 9 inches when added via the mixer pump burrowing ring.

3. Water addition to the top of the crust, as added via the transfer system vent line isolation valve $\mathrm{V}-355$, is limited to $30 \mathrm{kgal}$. 


\subsection{PROCESS CONTROL}

\section{WASTE TRANSFER}

The expected waste level in tank 241-SY-101 prior to transfer will be about 450 inches. A transfer of about $96 \mathrm{kgal}$ is expected to eventually reduce the tank level by a corresponding volume. This volume provides margin to avoid filling the tank to a level above the primary/secondary tank interface. The original range of the initial waste transfer volume (100 to $150 \mathrm{kgal})$ was specified for various reasons:

(1) $100 \mathrm{kgal}$ of waste removal from tank 241-SY-101 is about the smallest transfer that would create volume for sufficient dilution to permit dissolution of sodium nitrite solids in the crust. It is believed that this dissolution is sufficient to alter the crust properties enough to largely eliminate the crust gas retention problems.

(2) A transfer of more than $150 \mathrm{kgal}$ from tank 241-SY-101 without concurrent dilution might create interference problems between the crust and the mixer pump inlet and may create untoward impacts on DST operational volume and planning.

For the subsequently identified issue of potential crust sinking prior to sufficient analysis of the event, the initial waste transfer volume was refined and stated as $96 \mathrm{kgal}$ (Barton 1999).

The removal of the waste volume from tank 241-SY-101 will reduce the heat load and eventually lower the bulk waste temperatures in the tank. The result of such a temperature reduction, in the absence of any water dilution, may be to precipitate additional salts resulting in additional crust growth, potentially negating the benefit of the waste removal. This issue has been analyzed (Antoniak 1998). Results show that the removal of $100 \mathrm{kgal}$ of waste should eventually lower the bulk temperature of the tank wastes by $5{ }^{\circ} \mathrm{F}$. This temperature reduction might cause the precipitation of up to 18 additional inches of solids. Operational actions will serve to alleviate concerns over additional solids precipitation. For example, reduction of tank 241-SY-101 heat-loss rate via reduction of the tank annulus or primary ventilation-rates may be considered.

Tank back-dilution is specified as the next step in remediation activities for this tank, and it is known that the affects of planned water dilution greatly outweigh the opposing physical effects of cooling of tank wastes (Person 1999, Erhart 1999; Reynolds 1998).

The primary operational concern of the transfer system is to prevent line plugging due to inadvertent cooling of undiluted waste within the system transfer lines. The transfer system incorporates multiple features to protect against this occurrence:

(1) Heat tracing on the Water Support Skid and the overground transfer line to protect against temperature induced solids precipitation within transfer lines. 
(2) Multiple temperature indication incorporated throughout the transfer system.

(3) Maximum permitted water flow rates based upon support infrastructure heating capabilities.

(4) Heated water dilution and flush capabilities to either protect against the insertion of saturated salt solutions in system transfer lines - or - to remove these solutions immediately should an upset condition introduce them to the transfer lines.

(5) An nitrogen powered, 90-gallon heated water flush accumulation tank (ACC-401) to provide flush capability to the system should a loss of electric power occur.

(6) Water supply line and waste transfer line magnetic flow meters providing volumetric flow indication. These flow rates are the most immediate indication of the dilution achieved within the P-350. At periodic intervals the indicated transfer line flow rates can be compared to level changes in tank 241-SY-102. P-350 pump speed, transfer control valve positions, and the Water Support Skid regulation pressure are all adjusted to maintain the desired waste transfer and dilution water supply flow rates.

Operationally, the primary process control concern during transfer is control of the in-line dilution of waste pumped from tank 241-SY-101. Specifically, controlling the in-line dilution achieves control over the density of the transferred waste slurry. By controlling the slurry density and temperature within preferred ranges, the best balance can be achieved between the often-conflicting requirements of viscosity, critical velocity, and impact on the DST system operational volume. The ideal slurry density range with which to operate the transfer system and the in-line dilution to achieve this density are discussed in Section 6.1.

This section makes reference to the two process and instrumentation drawings (P\&IDs) that depict the transfer system and its dedicated water supply. These drawings are H-14-103656, "RAPID MITIGATION SYSTEM P\&ID," and H-14-03657, "WATER SUPPORT SYSTEM P\&ID." Drawing H-14-103656 is reproduced in Figure 7-1 and drawing H-14-103657 is reproduced in Figure 7-2, pages 1 and 2 . 


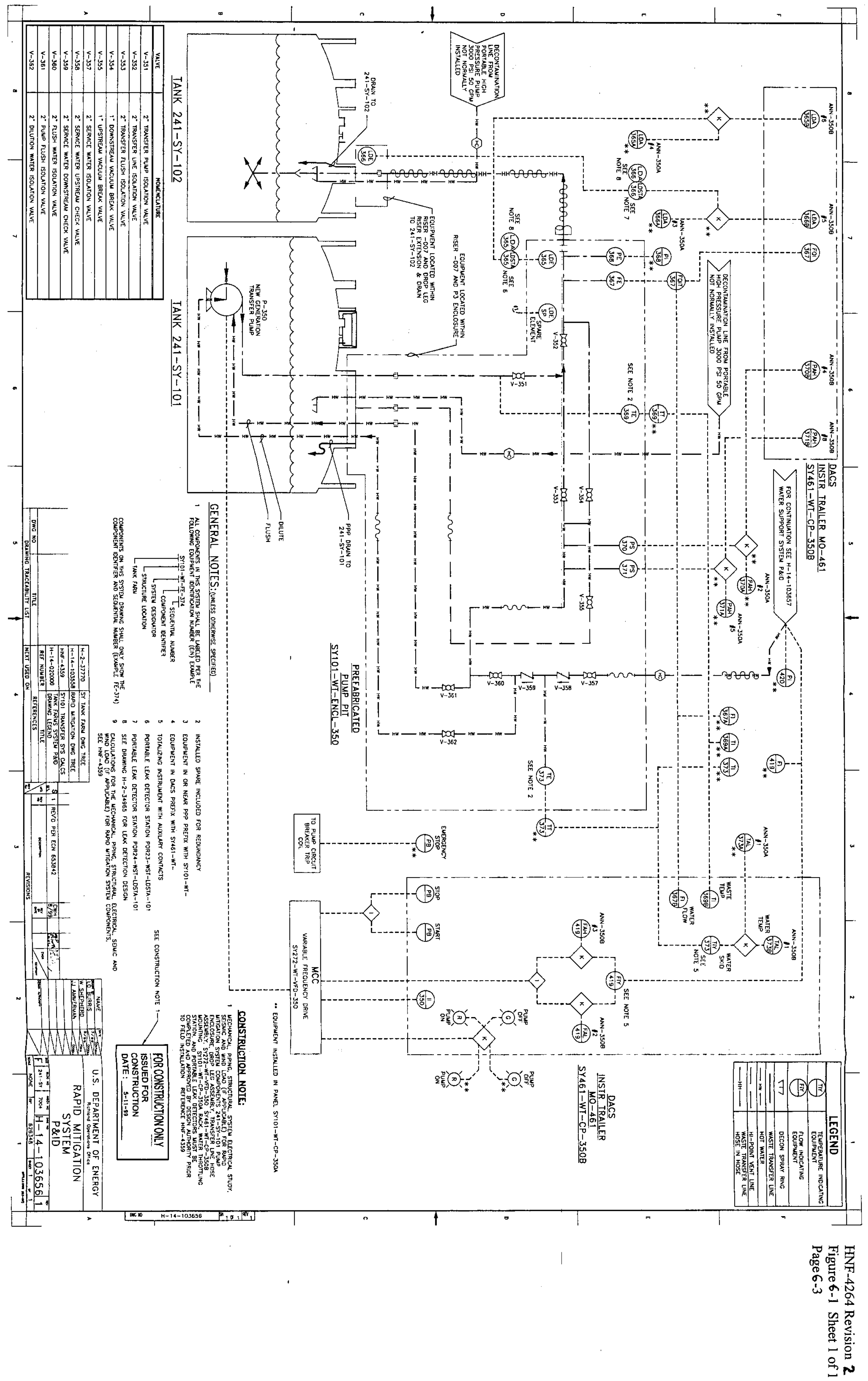




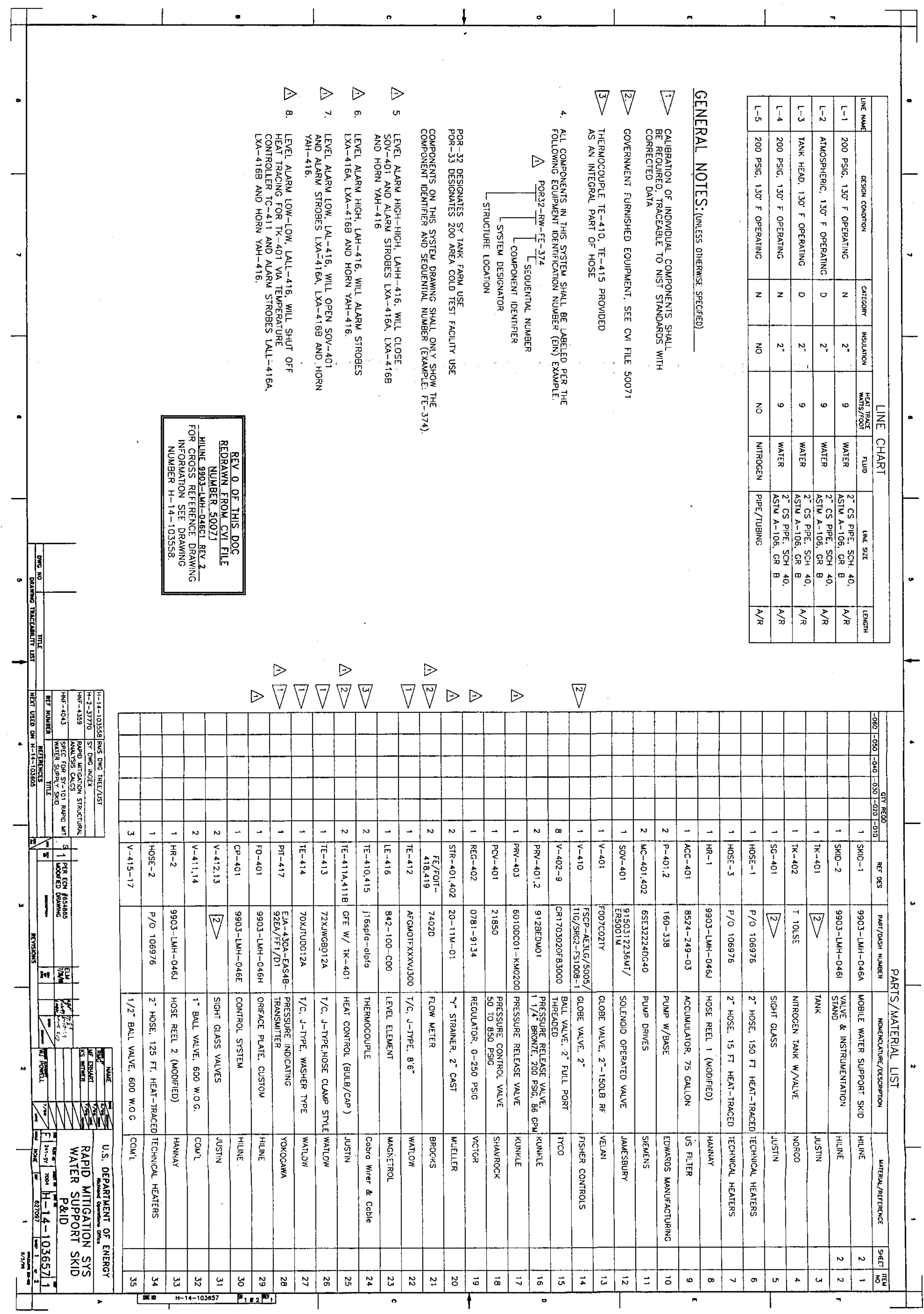




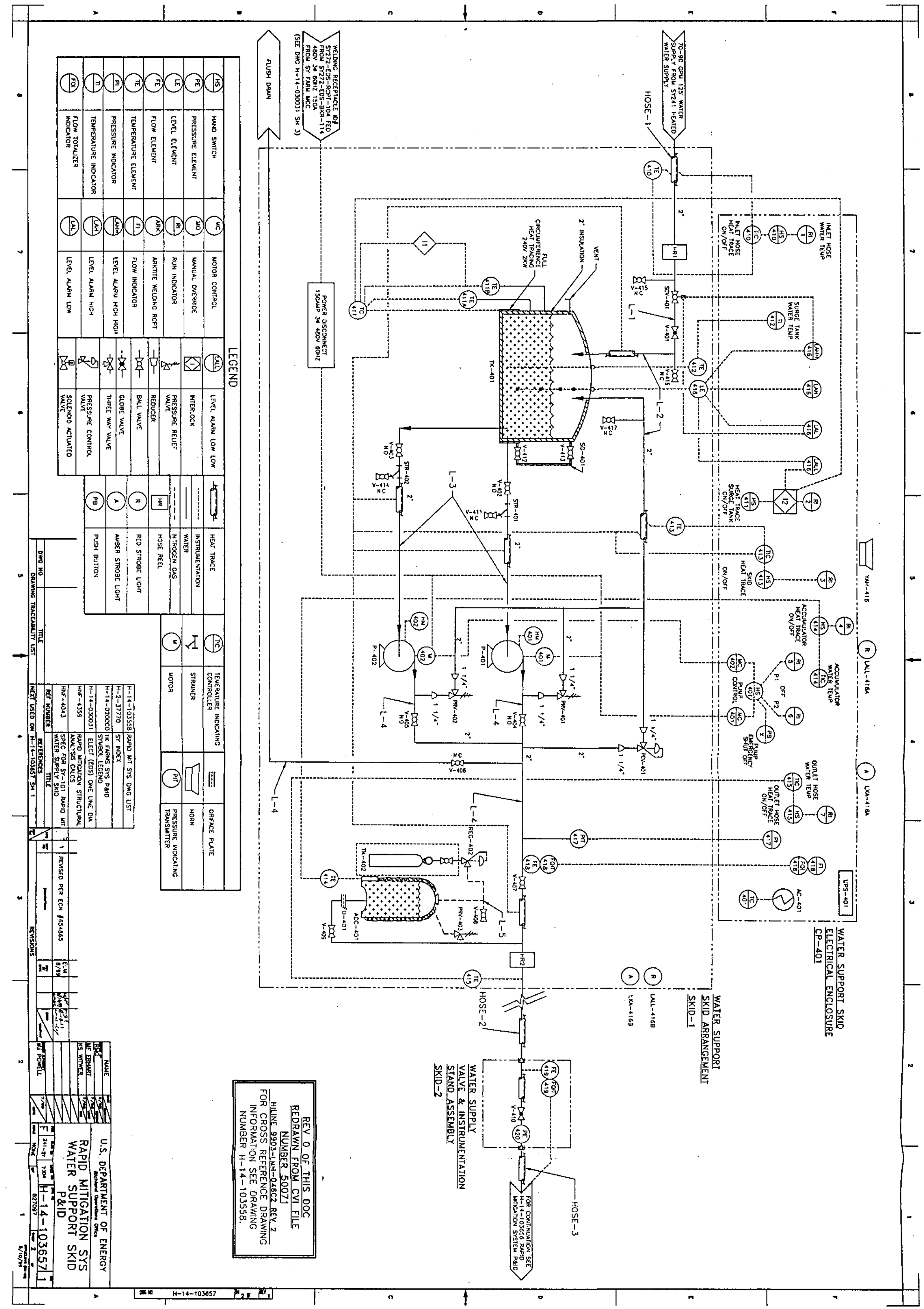




\section{BACK-DILUTION OF TANK 241-SY-101 WASTES}

Following the initial transfer of waste from tank 241-SY-101, in-situ water dilution of the remaining waste in the tank will be performed. It is planned that any additional transfer out of tank 241-SY-101 will be followed by back-dilution.

In early May 1999, the TAP recommended that the project develop and evaluate potential solutions to the problem posed by gas retention as soon as possible and before proceeding with tank back-dilution following the first small transfer (150K gal). At that time the Project Plan proposed a six-month interval between the first transfer and the first tank back-dilution.

Since that time, the project has completed dilution studies on core samples, evaluated the effects of applying dilution water to the surface of the crust, and determined the effect of the mechanical mitigation arm on gas releases and disruption of the crust. In addition, since then, the tank characteristics have changed dramatically. The surface level rise has stopped (in fact, it has decreased about three inches since mid-May 1999), and the tank started releasing more gas than is being generated.

Soon (days) after the initial $96 \mathrm{kgal}$ waste transfer from tank 241-SY-101, up to $72 \mathrm{kgal}$ of water (Barton 1999) will be introduced into tank 241-SY-101 in both the mixed slurry layer via the transfer pump (P-350) or the tank 241-SY-101 mixer pump burrowing ring. Additionally, up to $30 \mathrm{kgal}$ of water is to be added on top of the crust via valve V-355.. The tank back-dilution plan has up to $30 \mathrm{kgal}$ of water being added on top of the crust and approximately $30 \mathrm{kgal}$ being added to the convective waste through the transfer pump. Any further water addition (up to a total of 72,000 gallons) to the mixed slurry layer through the transfer pump or mixer pump burrowing ring will be based upon the tank conditions and/or as a mixer pump operation recovery action.

The initial waste transfer and tank back-dilution is only a first step in a series of two or more transfers from tank 241-SY-101 (totaling at least $300 \mathrm{kgal}$ ), each followed by tank back-dilution, needed to remediate crust growth and gas retention. It is currently anticipated that the majority of dilution water during the follow-on dilution sequences can be made directly to the convective layer wastes with the intention of sinking the softened and minimized volume of remaining crust.

Over the period of the remediation project, various reasoning and objectives for tank 241-SY-101 tank back-dilutions have been postulated:

1) Maintain mixer pump function by preventing the convective waste from transitioning to non-convective waste due to the expected bulk temperature decrease following the initial transfer.

2) Maintain mixer pump function by displacing the crust such that the solids in the crust do not interfere with the mixer pump inlet.

3) Maintain mixer pump function by preventing the formation of additional solids and/or trapped gas in the crust. 
4) Attempt some amount of degassing of the crust.

5) Dissolve soluble solids not necessarily in the crust.

6) Reduce gas generation rates in the tank by reducing the concentrations of chemical reactants and reducing the radioactive source terms.

7) Establish physical conditions in the tank that prevent the occurrence of BD GRE's, or at least greatly reduce their severity.

8) Drive the bulk tank waste density towards a value (i.e., $<1.41 \mathrm{SpG}$ ) not requiring special waste transfer analysis per the RPP Waste Compatibility Program.

9) Ultimately eliminate the need for mixer pump operation.

These objectives may not be listed in order of priority and may change depending upon the specific tank back-dilution sequence taking place.

The tank 241-SY-101 Surface-Level-Rise Remediation Project recognizes that transfer of $96 \mathrm{kgal}$ of waste will not fully resolve the issues associated with the gas retained in the crust of tank 241-SY-101 and its associated level growth. The Project Plan states that dilution will be evaluated following the initial transfer and that a series of transfer / dilutions steps will be used to resolve the level rise and buoyant displacement-gas release event (BD-GRE) issues. However, at the time it was envisioned that the dilution process would not be performed until conditions had been evaluated for a few months after the initial transfer. The plan was based on a philosophy of taking small steps, evaluating the effects and adjusting the plan as required. Since the Project Plan was written the understanding of the conditions in the tank has increased. It is considered safely achievable to initiate dilution within days after the initial transfer with the intent to complete all transfer/dilution steps to remediate the tank in FY 2000. This would be nearly one year ahead of the schedule in the project plan.

The SLRRP objectives will necessitate at least two sequences of transfer \& dilution operations. The logic of the tank back-dilution process is shown in Figure 6.3: 
Figure 6-3. Initial Tank Back-Dilution Logic

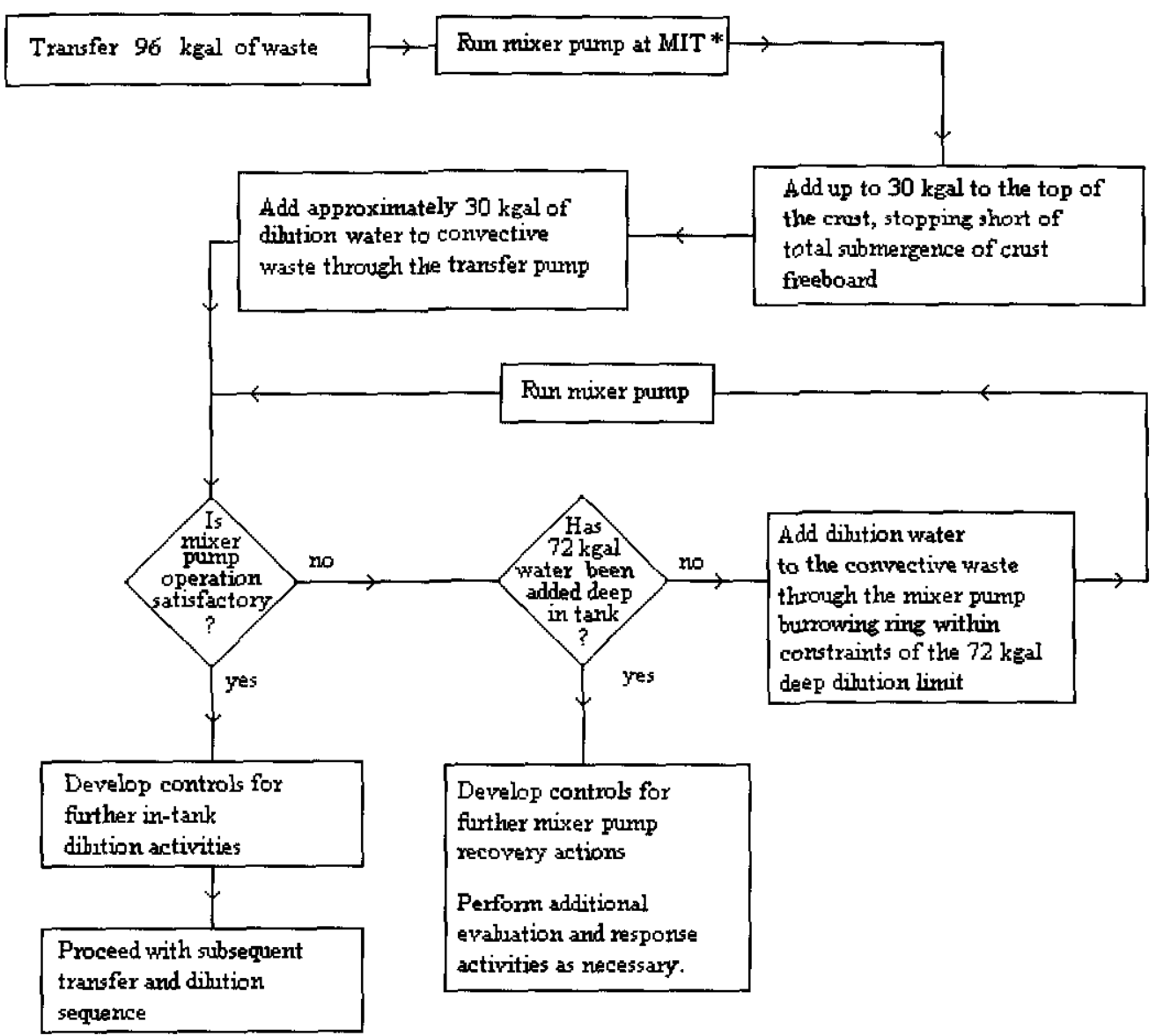

*optional - depending upon time since last mixex pump num

This initial dilution logic was selected because:

1) It can be implemented quickly and at low cost.

2) It makes maximum use of existing equipment and procedures.

3) It will ensure that the crust is raised away from the mixer pump suction and slightly diluted to combat against the effects of waste cooling expected to follow the waste transfer.

4) It will dissolve solids in the tank in a manner judged to represent minimum project risk (by preventing sinking of the crust until significant crust and convective waste dissolution has occurred).

Some points regarding the logic of the first tank back-dilution shown in Figure 7-3 need additional emphasis. The addition of water to the top of the crust will be in a controlled manner such that a portion of the crust freeboard remains visible. It is expected that dissolution of the crust freeboard will occur fairly rapidly and any dissolution of the freeboard will reduce the bulk density of the crust. Therefore, adding water to the point 
of total submergence of the crust results in the needless volume addition to the volume of tank 241-SY-101, since it is believed that any excess water added to the top of the crust can perform no other dissolution of tank solids. Additionally, the maturation of safety basis controls will only permit the initial addition of $30 \mathrm{kgal}$ to the top of the crust. Water addition to the convective wastes will be specified based upon ongoing analysis. Currently, the convective waste dilution water additions are envisioned as an initial 30 kgal through the transfer pump. If needed for recovery of mixer pump operation, another $42 \mathrm{kgal}$ may be added through the mixer pump burrowing ring. Maturation of the ongoing analyses and revision of Contractor approved prudent controls may alter these allowable dilution water volumes.

Any dilution of the convective waste necessitated by mixer pump operation recovery actions is likely to be via the mixer pump burrowing ring. The concern is that the mixer pump may not be providing the desired agitation of the tank waste. Therefore, if the water were added through the transfer pump, there is the potential that no or insufficient dilution would occur in the convective waste below the 96" level in the tank. By adding this water through the mixer pump burrowing ring, the lower regions of the convective layer will at least be agitated by the buoyant displacement of the water as it rises through the convective waste.

Desired effects of crust dilution are to: (1) directly address the mixer pump clearance issue by dissolving the "solids" matrix of the bubbly slurry, both releasing trapped gas in the crust and raising the elevation of the bottom of the crust, (2) to help in creating a direct path for the released gas to escape from the crust to the tank headspace, (3) to help remove trapped gas volume in the crust by absorption of soluble gases in the dilution water $\left(\mathrm{N}_{2}, \mathrm{~N}_{2} \mathrm{O}, \mathrm{NH}_{3}\right)$, (4) to reduce the bulk density of the crust to minimize the probability of unintended sinking of the crust.

Table 6-1 lists physically possible tank back-dilution options.

Table 6-1 Tank Back-Dilution Options

\begin{tabular}{|c|}
\hline Water Addition Location \\
\hline Transfer Pump to convective waste layer \\
\hline $\begin{array}{c}\text { Mixer Pump Burrowing Ring to convective waste layer } \\
\text { (this option applies only for recovery of mixer pump operation or performance) }\end{array}$ \\
\hline MMA to crust \\
\hline Mixer Pump Inlet to bottom of crust \\
\hline Transfer System Vent to top of crist \\
\hline
\end{tabular}




\subsection{OPERATIONAL CONTROL SCHEME}

\section{Devices and Monitoring Parameters for Process Control}

The control devices listed in Table 6-2 are used to regulate the volumetric flow rates through the transfer system piping. As a result, this allows the dilution of the transferred slurry to be controlled.

Table 6-2 Transfer System Flow Control Devices

\begin{tabular}{|l|r|r|}
\hline Control of Flush/ Dilution Water Flow & $\begin{array}{r}\text { WSS discharge pressure regulation valve PCV-401 } \\
\text { FCP process water throttle valve V-410 } \\
\text { ACC-401 nitrogen Flask Regulated Pressure }\end{array}$ \\
\hline
\end{tabular}

The instruments listed in Table 6-3 monitor the process parameters of the transfer system. These parameters are concerned with control of the waste dilution and transfer rate.

Table 6-3 Selected New Instrumentation for RAPID Transfer System (2 Sheets)

\begin{tabular}{|c|c|c|}
\hline $\begin{array}{l}\text { Process } \\
\text { Parameter }\end{array}$ & $\begin{array}{l}\text { Element } \\
\text { and } \\
\text { Location }\end{array}$ & $\begin{array}{l}\text { Display } \\
\text { and } \\
\text { Location }\end{array}$ \\
\hline \multirow[t]{2}{*}{ Water Supply Flow rate } & $* \mathrm{FE}-419$ & *FIT-419 \\
\hline & $\mathrm{FCP}$ & $\mathrm{FCP}$ \\
\hline \multirow[t]{2}{*}{ Water Supply Flow Totalizer } & *FE-419 & *FQI-419 \\
\hline & FCP & $\mathrm{FCP}$ \\
\hline \multirow[t]{2}{*}{ Water Supply Temperature } & *TE-373 & *TI-373 \\
\hline & PPP & FCP \\
\hline \multirow[t]{2}{*}{ Water Supply Pressure } & $* \mathrm{PE}-420$ & $* \mathrm{pI}-420$ \\
\hline & $\mathrm{FCP}$ & FCP \\
\hline Transfer Line Flow rate & SY-101-WT-FQIT-367 & $\begin{array}{c}\text { SY-101-WT-FQIT-367 } \\
\text { FCP }\end{array}$ \\
\hline
\end{tabular}


Table 6-3. Selected New Instrumentation for RAPID Transfer System (2 Sheets)

\begin{tabular}{|c|c|c|}
\hline $\begin{array}{c}\text { Process } \\
\text { Parameter }\end{array}$ & $\begin{array}{l}\text { Element } \\
\text { and } \\
\text { Location }\end{array}$ & $\begin{array}{l}\text { Display } \\
\text { and } \\
\text { Location }\end{array}$ \\
\hline Transfer Line Flow Totalizer & $\begin{array}{c}* * \mathrm{FE}-367 \\
\mathrm{PPP}\end{array}$ & $\begin{array}{c}* * \mathrm{FQIT}-367 \\
\text { FCP }\end{array}$ \\
\hline Transfer Line Temperature & $\begin{array}{c}* * \text { TE-369 } \\
\text { PPP }\end{array}$ & $\begin{array}{c}* * \mathrm{TI}-369 \mathrm{~A} \\
\text { FCP }\end{array}$ \\
\hline Transfer Line Pressure & $\begin{array}{c}* * \text { PE }-368 \\
\text { PPP }\end{array}$ & $\begin{array}{c}* * \mathrm{PI}-368 \mathrm{~A} \\
\text { FCP }\end{array}$ \\
\hline WSS Inlet Hose Temperature & $\begin{array}{l}* \text { TI-410 } \\
\text { WSS }\end{array}$ & $\begin{array}{l}* \text { TI-410 } \\
\text { WSCP }\end{array}$ \\
\hline TK-401 Temperature & $\begin{array}{c}* \mathrm{TI}-412 \\
\text { WSS } \\
\end{array}$ & $\begin{array}{l}{ }^{*} \mathrm{TI}-412 \\
\text { WSCP }\end{array}$ \\
\hline ACC-401 Temperature & $\begin{array}{c}* \mathrm{TE}-414 \\
\text { WSS }\end{array}$ & $\begin{array}{l}{ }^{* \mathrm{TI}-414} \\
\text { WSCP }\end{array}$ \\
\hline PPP Leak Detection Alarm & $\begin{array}{c}* * \text { LDE-365 } \\
\text { PPP }\end{array}$ & $\begin{array}{c}* * \mathrm{LDA}-365 \\
\text { FCP }\end{array}$ \\
\hline $\begin{array}{l}\text { Transfer Line and Drop Leg } \\
\text { Leak Detection Alarm }\end{array}$ & $\begin{array}{c}* * \mathrm{LDE}-366 \\
\text { tank } 241-\mathrm{SY}-102\end{array}$ & $\begin{array}{c}* * \text { LDA-366 } \\
\text { FCP }\end{array}$ \\
\hline $\begin{array}{c}\text { Transfer Leak-By Pressure } \\
\text { Switch/Alarm }\end{array}$ & $\begin{array}{l}* * \text { PS }-370 \\
\text { PPP }\end{array}$ & $\begin{array}{c}* * \mathrm{PAH}-370 \mathrm{~A} \\
\text { FCP }\end{array}$ \\
\hline $\begin{array}{l}\text { TK-401 Low / Low-Low Water } \\
\text { Level Alarms }\end{array}$ & $\begin{array}{c}* \text { LE-416 } \\
\text { WSS }\end{array}$ & $\begin{array}{c}* \text { LAL-416 / LALL-416 } \\
\text { WSCP }\end{array}$ \\
\hline $\begin{array}{l}\text { TK-401 High / High-High Water } \\
\text { Level Alarms }\end{array}$ & $\begin{array}{c}\text { *LE-416 } \\
\text { WSS }\end{array}$ & $\begin{array}{c}\text { *LAH-416 / LAHH-416 } \\
\text { WSCP }\end{array}$ \\
\hline
\end{tabular}

*POR32-RW-

**SY101-WT-

Table 6-4 provides a summary of instrumentation used to support the operation of the transfer system. These controls are composed of indications and alarms that signal the presence of a threshold condition which requires some sort of operator action. 
Table 6-4. Tank 241-SY-101 Transfer System Process Control Features

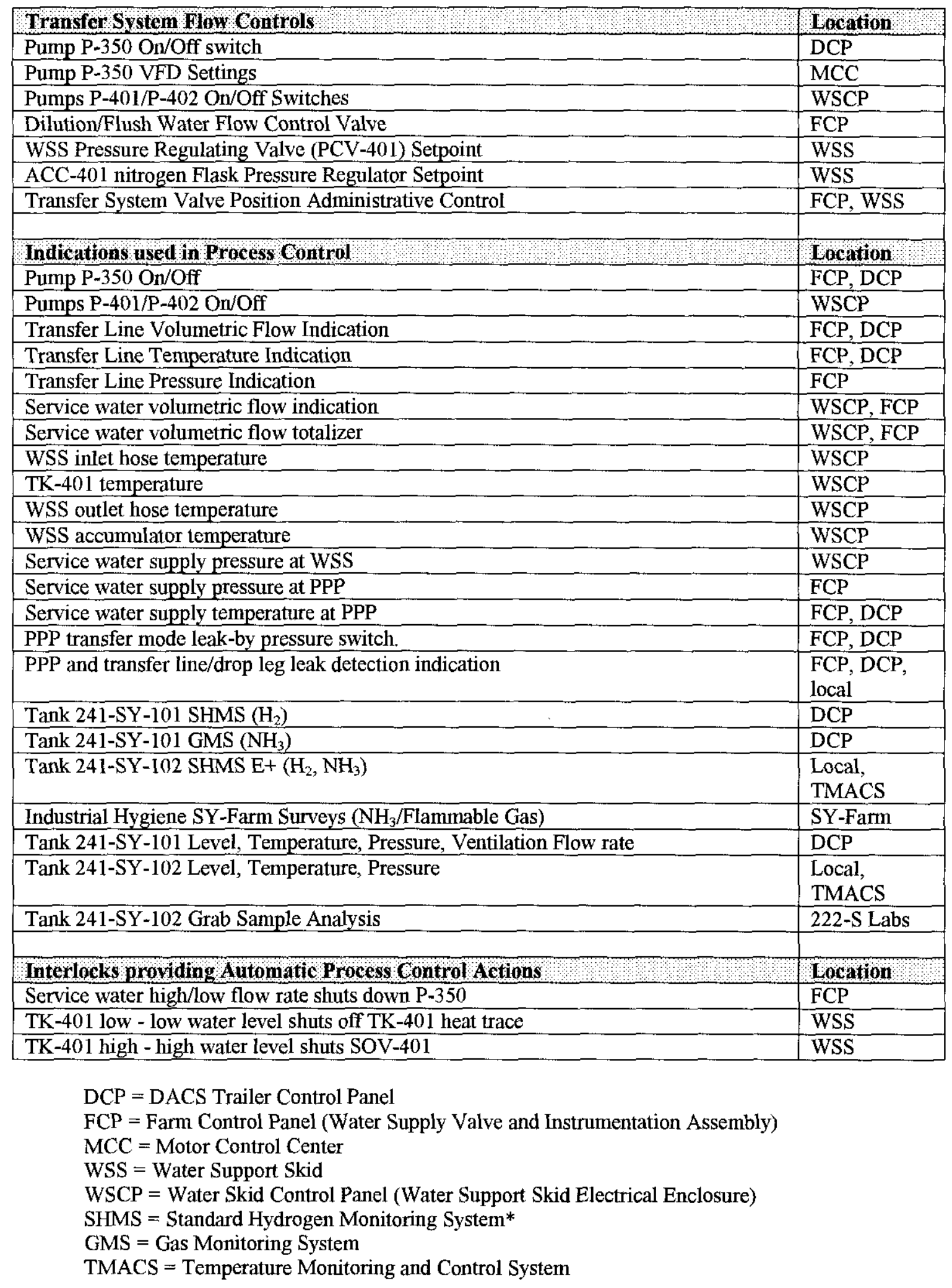


Tables 6-5 through 6-9 provide a summary of the requirements placed upon instrumentation used to support the operation of the transfer system.

Table 6-5. Flow Instrument Loops Performance Per HNF-4972

\begin{tabular}{|c|c|c|c|c|c|}
\hline $\begin{array}{l}\text { Instrument } \\
\text { toop }\end{array}$ & Description & $\begin{array}{l}\text { Range of } \\
\text { Process } \\
\text { Variable }\end{array}$ & $\begin{array}{l}\text { Range of } \\
\text { Indication }\end{array}$ & $\begin{array}{l}\text { Accuracy of } \\
\text { Indication }\end{array}$ & $\begin{array}{l}\text { Setpoint(s) of } \\
\text { Alarm(s) driven } \\
\text { by the } \\
\text { Instrument } \\
\text { Loop }\end{array}$ \\
\hline 367 & $\begin{array}{l}\text { Transfer Flow } \\
\text { Rate }\end{array}$ & 0 to $210 \mathrm{gpm}$ & 0 to $310 \mathrm{gpm}$ & $\begin{array}{l} \pm 15.5 \mathrm{gpm} \\
(\mathrm{FQIT}-367)\end{array}$ & N/A \\
\hline 367 & $\begin{array}{l}\text { Totalized } \\
\text { Transfer Flow }\end{array}$ & 0 to $550 \mathrm{kgal}$ & 0 to $10^{9} \mathrm{gal}$ & $\begin{array}{l} \pm 5.02 \% \\
(\text { FQIT-367) }\end{array}$ & N/A \\
\hline 418 & Water Flow Rate & 0 to $70 \mathrm{gpm}$ & 0 to $273 \mathrm{gpm}$ & N/A & $\mathrm{N} / \mathrm{A}$ \\
\hline 418 & $\begin{array}{l}\text { Totalized Water } \\
\text { Flow }\end{array}$ & 0 to $367 \mathrm{kgal}$ & 0 to $367 \mathrm{kgal}$ & N/A & N/A \\
\hline 419 & Water Flow Rate & 0 to $70 \mathrm{gpm}$ & 0 to $273 \mathrm{gpm}$ & $\begin{array}{l} \pm 2.81 \mathrm{gpm} \\
\text { (FQIT-419) }\end{array}$ & $\begin{array}{l}\text { High: } 70 \mathrm{gpm} \\
\text { Low: } 20 \mathrm{gpm}\end{array}$ \\
\hline 419 & $\begin{array}{l}\text { Totalized Water } \\
\text { Flow }\end{array}$ & 0 to $367 \mathrm{kgal}$ & 0 to $10^{9} \mathrm{gal}$ & $\begin{array}{l} \pm 1.16 \% \\
\text { (FQIT-419) }\end{array}$ & N/A \\
\hline
\end{tabular}

Table 6-6. Leak-Detection Instrument Loops Performance Per HNF-4972

\begin{tabular}{|c|c|c|c|c|c|}
\hline listrument & Description & $\begin{array}{l}\text { Range of } \\
\text { Process } \\
\text { Variable }\end{array}$ & $\begin{array}{l}\text { Desired Range } \\
\text { of lindication }\end{array}$ & $\begin{array}{l}\text { Accuracy of } \\
\text { Indication }\end{array}$ & $\begin{array}{l}\text { Setpoint(s) of } \\
\text { Alarm(s) driven } \\
\text { by the } \\
\text { Instrument } \\
\text { Loop }\end{array}$ \\
\hline 365 & Leak Detection & 1 & $\begin{array}{l}<5 / 8 \text { inch } \\
\geq \frac{5}{8} \text { inch }^{1}\end{array}$ & N/A & $10 \mathrm{k} \mathrm{ohm}$ \\
\hline 366 & Leak Detection & $T$ & $\begin{array}{l}</ 2 \text { inch } \\
\geq 1 / 2 \text { inch }^{1}\end{array}$ & N/A & $10 \mathrm{k}$ ohm \\
\hline
\end{tabular}


Table 6-7. Level Detection Instrument Loops Performance Per HNF-4972

\begin{tabular}{|c|c|c|c|c|c|}
\hline $\begin{array}{l}\text { Instrument } \\
\text { Loop }\end{array}$ & Description & $\begin{array}{l}\text { Range of } \\
\text { Process } \\
\text { Variable }\end{array}$ & $\begin{array}{l}\text { Desired Range } \\
\text { of Indication }\end{array}$ & $\begin{array}{l}\text { Accuracy of } \\
\text { Indication }\end{array}$ & $\begin{array}{l}\text { Setpoint(s) of } \\
\text { Aliarm(s) } \\
\text { Instrument } \\
\text { Loon }\end{array}$ \\
\hline 416 & $\begin{array}{l}\text { WSS: } \\
\text { TK-401 Level } \\
\text { High-High Alarm }\end{array}$ & 0 in. to 77.5 in. $*$ & N/A & N/A & 74 inches \\
\hline 416 & $\begin{array}{l}\text { WSS: } \\
\text { TK-401 Level } \\
\text { High Alarm }\end{array}$ & 0 in. to $77.5 \mathrm{in}$ * & $\mathrm{N} / \mathrm{A}$ & N/A & 64 inches \\
\hline 416 & $\begin{array}{l}\text { WSS: } \\
\text { TK-401 Level } \\
\text { Low Alarm }\end{array}$ & 0 in. to 77.5 in. $*$ & $\mathrm{~N} / \mathrm{A}$ & N/A & 36 inches \\
\hline 416 & $\begin{array}{l}\text { WSS: } \\
\text { TK-401 Level } \\
\text { Low-Low Alarm }\end{array}$ & 0 in. to 77.5 in.* & N/A & N/A & 30 inches \\
\hline
\end{tabular}

*TK-401 has an effective cylindrical operating height of 77.5 inches

Table 6-8. Pressure Detection Instrument Loops Performance Per HNF-4972

\begin{tabular}{|c|c|c|c|c|c|}
\hline $\begin{array}{l}\text { Instrument } \\
\text { Loop }\end{array}$ & Description & $\begin{array}{l}\text { Range of } \\
\text { Process } \\
\text { Variable }\end{array}$ & $\begin{array}{l}\text { Desired Range } \\
\text { of Indication }\end{array}$ & $\begin{array}{l}\text { Accuracy of } \\
\text { Indication }\end{array}$ & $\begin{array}{l}\text { Setpoint(s) of } \\
\text { Alarm(s) driven } \\
\text { by the } \\
\text { Instrument } \\
\text { Loop }\end{array}$ \\
\hline 368 & $\begin{array}{l}\text { Transfer Line } \\
\text { Pressure } \\
\text { Indication }\end{array}$ & 0 to $375 \mathrm{psig}$ & N/A & N/A & N/A \\
\hline 370 & $\begin{array}{l}\text { Flush Manifold } \\
\text { Pressure Sensor }\end{array}$ & 0 to 375 psig & N/A & $\overline{\mathrm{N} / \mathrm{A}}$ & 15 psig \\
\hline 371 & $\begin{array}{l}\text { Flush Manifold } \\
\text { Pressure Sensor }\end{array}$ & 0 to $375 \mathrm{psig}$ & N/A & N/A & 15 psig \\
\hline 417 & $\begin{array}{l}\text { WSS } \\
\text { Discharge } \\
\text { Pressure } \\
\end{array}$ & 0 to $200 \mathrm{psig}$ & 0 to $250 \mathrm{psig}$ & \pm 17.97 psig & $\overline{\mathrm{N} / \mathrm{A}}$ \\
\hline 420 & $\begin{array}{l}\text { PPP Water } \\
\text { Supply Pressure }\end{array}$ & 0 to 200 psig & 0 to $250 \mathrm{psig}$ & $\pm 12.5 \mathrm{psig}$ & N/A \\
\hline
\end{tabular}


Table 6-9. Temperature Instrument Loops Performance Per HNF-4972

\begin{tabular}{|c|c|c|c|c|c|}
\hline $\begin{array}{l}\text { Instrument } \\
\text { Loop }\end{array}$ & Bescription & $\begin{array}{l}\text { Range of } \\
\text { Process } \\
\text { Variable }\end{array}$ & $\begin{array}{l}\text { Desired Range } \\
\text { of Indication }\end{array}$ & $\begin{array}{l}\text { Accuracy of } \\
\text { Indication }\end{array}$ & $\begin{array}{l}\text { Setpoint(s) of } \\
\text { Alarm(s) driven } \\
\text { by the } \\
\text { Instrument } \\
\text { Loop }\end{array}$ \\
\hline 369 & $\begin{array}{l}\text { PPP waste } \\
\text { discharge } \\
\text { temperature }\end{array}$ & $102^{\circ}$ to $130^{\circ} \mathrm{F}$ & $32^{\circ}$ to $212^{\circ} \mathrm{F}$ & $\pm 7.76^{\circ} \mathrm{F}$ & N/A \\
\hline 373 & $\begin{array}{l}\text { PPP water } \\
\text { supply } \\
\text { temperature }\end{array}$ & $102^{\circ}$ to $130^{\circ} \mathrm{F}$ & $32^{\circ}$ to $212^{\circ} \mathrm{F}$ & $\pm 7.76^{\circ} \mathrm{F}$ & $114^{\circ} \mathrm{F}$ \\
\hline 401 & $\begin{array}{l}\text { WSS electrical } \\
\text { enclosure } \\
\text { temperature }\end{array}$ & $\overline{\mathrm{N} / \mathrm{A}}$ & $\mathrm{N} / \mathrm{A}$ & N/A & N/A \\
\hline 410 & $\begin{array}{l}\text { WSS water inlet } \\
\text { temperature }\end{array}$ & $102^{\circ}$ to $130^{\circ} \mathrm{F}$ & $32^{\circ}$ to $212^{\circ} \mathrm{F}$ & $\pm 27.7^{\circ} \mathrm{F}$ & $112^{\circ} \mathrm{F}$ \\
\hline 411 & $\begin{array}{l}\text { TK-401 wall } \\
\text { temperature }\end{array}$ & $102^{\circ}$ to $130^{\circ} \mathrm{F}$ & $32^{\circ}$ to $212^{\circ} \mathrm{F}$ & N/A & $132^{\circ} \mathrm{F}$ \\
\hline 412 & $\begin{array}{l}\text { TK-401 water } \\
\text { temperature }\end{array}$ & $102^{\circ}$ to $130^{\circ} \mathrm{F}$ & $32^{\circ}$ to $212^{\circ} \mathrm{F}$ & $\pm 27.7^{\circ} \mathrm{F}$ & N/A \\
\hline 413 & $\begin{array}{l}\text { WSS water } \\
\text { outlet } \\
\text { temperature }\end{array}$ & $102^{\circ}$ to $130^{\circ} \mathrm{F}$ & $32^{\circ}$ to $212^{\circ} \mathrm{F}$ & $\pm 27.7^{\circ} \mathrm{F}$ & $112^{\circ} \mathrm{F}$ \\
\hline 414 & $\begin{array}{l}\text { ACC- } 401 \text { wall } \\
\text { temperature }\end{array}$ & $102^{\circ}$ to $130^{\circ} \mathrm{F}$ & $32^{\circ}$ to $212^{\circ} \mathrm{F}$ & $\pm 27.7^{\circ} \mathrm{F}$ & $112^{\circ} \mathrm{F}$ \\
\hline 415 & $\begin{array}{l}\text { WSS outlet } \\
\text { flexible hose } \\
\text { temperature }\end{array}$ & $102^{\circ}$ to $130^{\circ} \mathrm{F}$ & $32^{\circ}$ to $212^{\circ} \mathrm{F}$ & $\pm 27.7^{\circ} \mathrm{F}$ & $112^{\circ} \mathrm{F}$ \\
\hline HT1 & $\begin{array}{l}\text { Transfer line } \\
\text { flex hose heat } \\
\text { trace thermostat }\end{array}$ & $102^{\circ}$ to $130^{\circ} \mathrm{F}$ & $\mathrm{N} / \mathrm{A}$ & $\begin{array}{l}\text { N/A (factory } \\
\text { calibrated only) }\end{array}$ & $130^{\circ} \mathrm{F}$ \\
\hline HT2 & $\begin{array}{l}\text { Transfer line } \\
\text { flex hose heat } \\
\text { trace thermostat }\end{array}$ & $102^{\circ}$ to $130^{\circ} \mathrm{F}$ & N/A & $\begin{array}{l}\text { N/A (factory } \\
\text { calibrated only) }\end{array}$ & $130^{\circ} \mathrm{F}$ \\
\hline
\end{tabular}

The key to reliable operation of the transfer system is to alter the physical properties of the waste removed from tank 241-SY-101 to make it more benign for fluid flow considerations and thus make the slurry pumping method more reliable. The change of the physical properties of the waste is achieved through dilution of the waste with heated water. The water dilution creates several beneficial changes in the properties of the waste:

(1) Immediate reduction of the waste density and more importantly, a proportionally larger reduction in the effective viscosity of the slurry. This produces the beneficial affect of increasing transport Reynolds numbers at a given flow velocity with the attendant reduction in the slurry flow critical velocity. 


\section{HNF-4264 REV. 2}

(2) The establishment of a concentration driving force to dissolve soluble solids in the waste slurry produced. Although the kinetics of the soluble solids dissolution is thought to be fairly well characterized, the time constants of the mechanisms are as long or longer than the transit time of the transfer system. However, great benefit is realized if an upset condition causes the slurry to be trapped in the transfer line. In this case, significant solids dissolution combats the effects of solids settling and additional precipitation, possibly avoiding a plugging situation.

Laboratory viscometry of the $\sim 1.5 \mathrm{SpG}$ pure liquid portion of the convective waste has shown a viscosity of about 10 to $13 \mathrm{cP}$ at a $50 \mathrm{sec}^{-1}$ shear rate and $120^{\circ} \mathrm{F}$ (Person 1999). When this liquid is diluted with one part water at $120^{\circ} \mathrm{F}$, the viscosity becomes $\cong 3 \mathrm{cP}$ at the $50 \mathrm{sec}^{-1}$ shear rate. Because of the presence of significant amounts of solids in the insitu convective wastes, the viscosity of this waste will be higher than its liquid-phase viscosity. It is currently estimated that the in-situ viscosity of the convective wastes in tank 241-SY-101 to be in the range of 50 to $200 \mathrm{cP}$ at a $50 \mathrm{sec}^{-1}$ shear rate.

Dilution of tank 241-SY-101 wastes with heated water is expressed by the dilution ratio (DR):

$$
\mathrm{DR}=\frac{\text { FQIT }-419}{\text { FQIT }-367}
$$

Where

$$
\mathrm{DR}=\text { dilution ratio }
$$

FQIT-419 = indicated dilution water flow rate

FQIT-367 $=$ indicated transfer line flow rate

With this definition, pure water flow corresponds to a dilution ratio of $\infty$, whereas pure waste flow corresponds to a dilution ratio of zero. Therefore a 1 part waste to 1 part water dilution corresponds to a $\mathrm{DR}$ of 0.5 since the indicated transfer line flow rate (FQIT-367) is the sum of equal parts of waste flow (not directly measured) and water flow rate (FQIT-419).

The low dilution limit of one part water to two parts waste $(\mathrm{DR}=0.33)$ has significant short-term implications since violating this limit produces the immediate result of filling the transfer line with concentrated salt solution. This is undesired since conceivable upset conditions could result in solids precipitation and potential plugging of the transfer line. The high dilution limit of two parts water to one part waste $(\mathrm{DR}=0.67)$ is not as time critical as the low-end limit since this results in the relatively slow addition of undesired water volume into the DST system.

If the control parameter values are automatically logged in a data logger, the material balance shall be done by the operator at startup, 30 minutes and 1 hour after startup and 
every two hours thereafter until shutdown when an additional material balance shall be performed. If automatic data logging is not available; the operator shall log the parameters and perform the material balance as above except the 2 hour frequency shall be reduced to every hour.

For the initial transfer from tank 241-SY-101, DR $=0.33$ is expected to equate to a diluted slurry density of $1.4 \mathrm{~kg} / \mathrm{L}$. Likewise, $\mathrm{DR}=0.5$ corresponds to a diluted slurry density of $1.3 \mathrm{~kg} / \mathrm{L}$, while $\mathrm{DR}=0.67$ corresponds to a diluted slurry density of $1.2 \mathrm{~kg} / \mathrm{L}$. As remediation activities progress on this tank, planned tank back-dilution will lower the waste density in tank 241-SY-101. As a result, for subsequent transfers the dilution ratios specified may be adjusted to achieve a desired diluted slurry density.

During start-up and shutdown of the transfer system, the high end of the steady-state DR range must be exceeded. Prior to starting pump P-350, dilution water flow must be established. By the dilution ratio criteria, this situation represents $\mathrm{DR}=\infty$. Then pump P-350 is started at a low speed that is slowly increased until the desired transfer flow rate (nominally 60 to $120 \mathrm{gpm}$ at the 1:1 dilution) is achieved. Similarly, at the point of intended pump P-350 shutdown, the value of DR should be as high as possible. This is achieved by ensuring that the transfer line flow rate is slowly adjusted to the minimum controllable or measurable value prior to P-350 pump shut down. This time period ensures that the transfer line contains waste with the maximum possible water dilution.

Section 6.3, Transfer Completion Criteria, discusses verification techniques for determining mass transfer between the tanks. These techniques may be used to obtain evidence that would suggest to a rough order, the amount of the water added to the system that actually did end up in tank 241-SY-102. However, these techniques can only be used when the system has been shutdown following a transfer.

When possible, the transfer system provides redundant indications for determining material balances. The listing of these "on-line" process measurements are shown in Table 6-10:

Table 6-10. Material Balance Indications

\begin{tabular}{|c|c|c|}
\hline Water Supply Flow & Waste Transfer Line Flow & Tank 241-SY 102 Receipt \\
\hline $\begin{array}{c}\text { POR32-RW-FQIT-419 } \\
\text { Service Water Totalized Flow } \\
\text { Indicator) }\end{array}$ & SY101-WT-FQIT-367 & SY-102-WST-LIT-101 \\
& Waste Transfer Flow Totalizer) & (Tank 241-SY-102 ENRAFTM level \\
gage) \\
$\begin{array}{c}\text { Instrument Accuracy } \\
\pm 1.16 \% \text { of totalized flow* }\end{array}$ & $\pm 5.02 \%$ of totalized flow* & Instrument Accuracy \\
& & \pm 0.04 inches $( \pm 110$ gal) \\
\hline
\end{tabular}

*Hickman (1999)

Per OSD-T-151-007, the allowable rate of temperature change in a DST with a $65^{\circ} \mathrm{F}$ temperature is $10^{\circ} \mathrm{F}$ per hour. Tank $241-\mathrm{SY}-102$ waste has an approximate temperature of $65^{\circ} \mathrm{F}$. The minimum volume of waste in tank 241-SY-102 at the start of the transfer is $500 \mathrm{kgal}$ at a nominal $65^{\circ} \mathrm{F}$ and $1.2 \mathrm{SpG}$. 
For the assumptions:

- at start of the transfer, tank $241-\mathrm{SY}-102$ contains $500 \mathrm{kgal}$ of $1.2 \mathrm{SpG}$ waste at $65^{\circ} \mathrm{F}$

- that the heat capacities of the waste in tank 241-SY-102 is equal to that of the waste slurry transferred from tank 241-SY-101 (0.75 Btu/lb)

- and the dilution water flow rate is $60 \mathrm{gpm}$ at $120^{\circ} \mathrm{F}$

The maximum hourly bulk waste temperature increase in tank 241-SY-102 is expected to be well below $1^{\circ} \mathrm{F}$ per hour. The $10^{\circ} \mathrm{F}$ per hour OSD limit will not be approached during the initial waste transfer from tank 241-SY-101.

\subsection{TRANSFER COMPLETION CRITERIA}

When the volumetric change indicated by the level rise in tank 241-SY-102 indicates that the predetermined volume of tank 241-SY-101 waste has been moved to tank 241-SY-102, the transfer will be terminated and a verification of the transfer volume will be performed. This transfer volume verification uses the totalized volume transferred to 241-SY-102 and the totalized water addition volume to calculate the volume of waste transferred. Other characterization information as available, may also be used as determined by Process Engineering. Examples could include analysis of the changes in the concentrations of certain analytes

\section{Transfer Termination Criteria}

When the volume change in tank 241-SY-102 minus the water volume added to the system equals the predetermined transfer volume of tank 241-SY-101 waste (nominally $96 \mathrm{kgal}$ )

The total volume of transferred waste must include allowance for the volume that may be siphoned in the time period between shutdown of the transfer pump and the establishment of the Administrative Lock on the system. As discussed in Section 6.6, the RAPID transfer system operating procedure must explicitly require the time at which the status of pump P-350 and valves V-362 and V-351 is changed to be recorded.

\subsection{DILUTION RATIO VERIFICATION}

Good operating practice requires the use for a continuous material balance. The material balance offers a way to double-check the performance of controlling the transfer line dilution ratio using FQIT-367. This function will be described subsequently. 
In the example of Section 7.3, the volume of tank 241-SY-101 waste transferred as indicated by the process instrumentation matches the volume determined by material balance verification to three significant figures. In actuality, there will be discrepancies between the two figures. Assuming a baseline tank 241-SY-101 waste transfer volume of $100 \mathrm{kgal}$ and baseline water addition volume of $100 \mathrm{kgal}$, the measurement errors that could be expected under ideal conditions are indicated in Table 6-10. This table provides a listing of the instrumentation that will permit transfer operation. In the event of failure of any of these instruments, the transfer must be terminated.

The concept of tank 241-SY-102 supernate density change is the only reliable means of determining if the water added to the system ends up in tank 241-SY-102 instead of tank 241-SY-101. Changes in various transfer pump performance parameters have been suggested as indicators for changes in the physical properties of the working fluid. However, these methods are generally deemed unsatisfactory for process control by themselves. Additionally, the significant crust and gas void volume in tank 241-SY-101 render any changes in tank level to be unusable for on-line process control.

There is reasonable confidence in the waste fluid properties and the pump design that, if the transfer pump is operated at a higher flow rate than the flow rate of dilution water to it, that the dilution water will be entrained by the pump and moved to tank 241-SY-102. There is also high confidence in the accuracy at which the volume changes in tank 241-SY-102 can be detected by the ENRAFTM level gage and in the accuracy at which the volume of water supplied to the PPP can be recorded via the instruments driven by FE-419.

This confidence suggests that a material balance can provide a check of the actual average dilution ratio achieved by comparing the level change in tank 241-SY-102 to the totalized volume of water supplied to the PPP. Any discrepancy of a certain threshold may indicate an undesired average dilution ratio may have been achieved. Alternatively, a material balance may provide indication of a malfunction of an instrument, a leak in the system, or indication that totalized FQIT-367 readings provide a poor measure of the actual transfer line flow.

Within a 30-minute time span, a nominal transfer line flow rate of 120 gpm would indicate a volume transfer of 3600 gallons. With a 110 gallon resolution on the ENRAF ${ }^{\mathrm{TM}}$ level gage in tank 241-SY-102, the level gage should be able to measure this volume change to within $(110 / 3600) * 100 \%$ or about $3.0 \%$. The repeatability of the ENRAFTM is an order of magnitude better than the accuracy $(0.004$ inch versus 0.04 inch). The accuracy of the volume transfer measurement in tank 241-SY-102 via the ENRAFTM $^{\mathrm{T}}$ should improve at each additional 30-minute measurement as the resolution of the ENRAF ${ }^{T M}$ in terms of the transferred volume increases. With the assumption that during waste transfer, all water supplied to the PPP is transferred to tank 241-SY-102, a continuous material balance can be reasoned. Referring to the definition of the dilution ratio (DR) from Section 6.1: 


$$
\mathrm{DR}=\frac{\text { FQIT }-419}{\text { FQIT }-367}
$$

Totalized (i.e., integrated) values of the respective flow rates serve to indicate the average dilution ratio achieved. This can be accomplished by substituting flow volumes for flow rate in the definition of $\mathrm{DR}$ :

FQIT-367 $\rightarrow$ volume change indicated by SY-102-WST-LIT-101

$\rightarrow$ volume change indicated by manually integrated FQIT-367 log readings

FQIT $-419 \rightarrow$ volume change indicated by FQIT-419

$\rightarrow$ volume change indicated by manually integrated FQIT-419 log readings

This expression forms a process control and summarizes the goal of slurry composition control. It indicates that at any time during the waste transfer, the ratio of the volume of water supplied to the PPP to the volume transferred into tank 241-SY-102 must be within the range of 0.33 to 0.67 .

The only volumetric measurement of the transfer flow that is qualified as Safety Class is FQIT-367. Therefore, the ENRAF gage in tank 241-SY-102 could only be used to terminate the transfer if it indicates that the total volume has been transferred and that this volume is less than that indicated by FQIT-367. The transfer volume as indicated by SY-102-WST-LIT-101 cannot be used to extend the transfer beyond the limiting volume as indicated through the use of the FQIT-367 indication.

With this limitation, the following data sources can be used at the shift manager's discretion to terminate the transfer when the material balance calculated using any of the data sources indicates that the desired volume has been moved from tank 241-SY-101 to tank 241-SY-102:

Tank 241-SY-102 volume increase
a) SY-102-WST-LIT-101 (SY-102 ENRAFTM)
b) SY101-WT-FQIT-367
c) Manually integrated SY101-WT-FQIT-367 log readings

Volume of water supplied to the PPP

a) POR32-RW-FQIT-419

b) Manually integrated POR32-RW-FQIT-419 log readings

It should be noted that this process control differs from the AC requirements of Sections 6.1 and 6.2:

a) Section 6.1 specifies an AC to provide a material balance for a leak-detection function. The absolute value of: 


$$
\text { (FQIT-367) }-\frac{2750 \mathrm{gal}}{\text { in }}(\Delta \text { level per SY-102-WST-LIT-101) }
$$

is monitored and additional leak-detection activities are specified if the magnitude of the value exceeds a certain limit at the time of observation.

b) Section 6.2 places an $\mathrm{AC}$ on the value of the total volume of material removed from tank 241-SY-101 as measured by ((FQIT -367)-(FQIT - 419)).

\subsection{SPECIFIC OPERATING INSTRUCTIONS FOR TRANSFER}

Process Engineering will determine a number of operational limits for the transfer. These limits will be communicated to Operations via a Process Memo prior to the transfer:

(1) The desired volume to be transferred from tank 241-SY-101

(2) The limiting volume to be transferred from tank 241-SY-101 (taken from HNF-IP-1266)

(3) The not-to-exceed level rise in tank 241-SY-102 (transfer will terminate if this level is reached)

(4) The not-to-exceed volume of water to be supplied to the PPP (transfer will terminate if this volume is reached.)

\subsection{CONTROL OF TANK BACK-DLUTION ACTIVITIES}

In order to achieve the final condition, the remediation project is currently planning to transfer at least $300 \mathrm{kgal}$ of waste with subsequent tank back-dilution of a similar volume of water. This transfer/dilution process will have to be done in steps approximately no larger than $150 \mathrm{kgal}$ because of several considerations:

1) constraints on drawdown of tank 241-SY-101 to protect the mixer pump operation

2) the available space in the receiver tank, 241-SY-102

3) constraints on adding water to tank 241-SY-101 intended to prevent inadvertent sinking of the crust.

Many options are available to accomplish the dilution process. The selection of the specific option is dependent upon the specific goals of each step. The project has considered many variables including location, rate, temperature, method of mixing, volume per step, etc. Different method/condition of water addition may be used as the project progresses down this path consistent with the project philosophy of taking small steps quickly.

Initially, dilution water will be added directly on the top of the crust without controls specified on the water temperature. Depending upon the behavior of the visible portions of the crust, up to $30 \mathrm{kgal}$ may be added in this fashion. At the nearest convenient opportunity, operation of the mixer pump will be investigated. 
Following this, $30 \mathrm{kgal}$ of water heated to the bulk tank temperature will be injected into the mixed slurry layer at an elevation of $8 \mathrm{ft}$ through the inlet of the transfer (P-350) pump. The water thus introduced will be buoyant with respect to the surrounding convective waste. Buoyant mixing will occur as the water the plume rises through the convective layer to the base of the crust.

The concept to verify mixer pump operability will be to, after initial waste transfer, review the mixer pump operating parameters following each pump run for evidence of mixer pump performance degradation. This review after each pump run will continue until the TRG determines that changed tank conditions have not significantly degraded the capability of the mixer pump to perform its intended function. In addition, the normal quarterly review of mixer pump performance would continue. If the analysis shows the mixer pump operation to be degraded, an additional $42 \mathrm{kgal}$ of dilution water may be added to the convective waste through the mixer pump burrowing ring.

The dilution water will be introduced at a moderate rate, limited to $70 \mathrm{gpm}$ by system design. The indications used to monitor and initiate control responses to the water addition rate are discussed in Section 7.6. Primarily, the control responses intend to ensure tank atmospheric fuel concentrations remain below $25 \% \mathrm{LFL}$.

\subsection{INHERENT OPERATIONAL CONCERNS}

\section{Tank to Tank Siphoning}

It has been determined (Meyer \& Biggs 1999) that at the point of transfer pump (P-350) shutdown following a waste transfer, while dilution water is still supplied to the PPP, siphoning action between tanks 241-SY-101 and -102 will continue to "transfer" waste from tank to tank at rates of up to $8 \mathrm{gpm}$ (on an undiluted basis). This equates to the 2,000 gallon capacity of TK-401 being capable of siponing up to 1150 gallons of waste to tank 241-SY-101. It is noted that active measures are required to stop the siphoning action. Unless the dilution water is running more than $40 \mathrm{gpm}$, waste siphoning will occur when the transfer pump is stopped. (At greater than $40 \mathrm{gpm}$, the water flow to pump P-350 exceeds the siphon flow rate, preventing waste from entering the pump). This could result in the transfer pump filling with waste when 241-SY-101 siphons to 241-SY-102.

The impact of the siphoning potential is addressed in the TSR for Administrative Lock on tank farm equipment. For implementation of AC 5.20 for the Tank 241-SY-101 RAPID Mitigation System, the Administrative Lock condition is demonstrated by:

Removing and securing the motive force (i.e., electrical power) from the pump

AND 
Closing and securing either Valve V-362 or V-351 and securing either in the closed position to remove the motive force for siphoning.

Securing of the motive force to the transfer pump is accomplished by application of an Administrative Lock condition, either with an installed lock mechanism on the pump's motor controller OR by stationing a qualified operator to maintain the motive force in a secure configuration. Securing of the valve in the closed position is accomplished by application of an Administrative Lock condition with an installed lock mechanism on the valve. Application of the Administrative Lock Program requirements to the designated valves is a contractor-imposed prudent control necessary to safely perform crust growth remediation actions for Tank 241-SY-101 (French 1999).

This interpretation requires the assumption that for any condition of the transfer system when the transfer line is full and dilution water supplied to the transfer pump, siphoning at $8 \mathrm{gpm}$ occurs during the time period between stopping the transfer pump and establishing the TSR Administrative Lock per AC 5.20. The operational implication of these prudent contractor imposed controls is that the status of pump P-350 (on / off), valve V-262 (open / shut) and valve V-351 (open / shut) must be chronologically qualified. Associating the status changes of these three pieces of equipment with a time stamp allows determination of the amount of time the RAPID transfer system is maintained in a configuration allowing the possible siphoning of waste at $8 \mathrm{gpm}$. Therefore the RAPID transfer system operating procedure must explicitly require the time at which the status of pump P-350 and valves V-362 and V-351 is changed to be recorded.

Flushing of the RAPID transfer system (including pump P-350) must be performed following termination of waste transfer operations. The establishment of a hydraulic lock must follow the completion of flushing operations on pump P-350. Specifically, hydraulic lock is placed on pump P-350 whenever the RAPID transfer system is returned to the stand-by configuration (i.e., all process valves are shut - see Section 4.2.1).

\section{Process Volumetric Measurements}

The objective of the transfer will be to move a specified volume of waste from tank 241-SY-101, mixing it with a specified volume of water, and transporting the waste to tank 241-SY-102. The transfer will be continued until the volume of waste transferred as measured by the material balance techniques equals the desired transfer volume. The assumption of these "on-line" or "real-time" process control measurements is that the volume of waste transferred from tank 241-SY-101 and the volume of dilution and flush water supplied to the PPP are additive in tank 241-SY-102. Three points are made about this:

(1) The error inherent in this assumption (less than 3\%) is insignificant to the "real-time" process decisions. 
(2) After shutdown of the transfer, "off-line" measurement (i.e., verification) techniques, as discussed in Sections 6.4 and 6.5, will determine the effect of supernate density changes on the resulting level in tank 241-SY-102 to determine if the current level actually corresponds to the transfer termination criteria.

(3) It is assumed that one part by volume tank 241-SY-101 waste and one part by volume water forms two parts by volume diluted waste.

The magnetic flow meters provided for the transfer system indicate volumetric measurements only, and cannot discern densities or mass flow rates. Level changes in tank 241-SY-102, while measured easily, do not account for changes in waste density or gas content. Additionally, level changes in tank 241-SY-101 that may occur as a result of the transfer cannot be reliably predicted or used as a process control measurement due to the potential for gas release. Thus the "on-line" process control measurements will be incapable of determining the relationship between the volume of dilution water supplied to the PPP and the volume of dilution water transferred to tank 241-SY-102.

The concern of where the water added to the system ends up may never be completely addressed. It is expected that when pump P-350 is running at a flow rate in excess of the dilution water flow rate that the majority of the water injected at the inlet of the pump will be entrained. Even if a small amount of dilution water impinges on the pump P-350 inlet screen with sufficient velocity to overcome the pressure drop across the screen, it should be rapidly entrained by the waste moving towards the inlet and thus return to the pump. If, however, a small volume of water can escape completely from the inlet of pump P-350 and buoy itself upward towards the crust, the instrumentation of the system will probably be incapable of detecting it. Even if this does occur, the $25 \%$ lower flammability limit (LFL) and ignition controls established for remediation activities (French 1999) control any undesired effects that may result.

Cold testing of the transfer pump has shown the potential for leakage around the press fit joints in the pump housing. This leak has been variously estimated from less than $1 \mathrm{gpm}$ to $5 \mathrm{gpm}$. This leakage is reduced at higher temperature through better sealing. There is no way to account for this leakage in the material balance because no method exists to measure the actual leakage during transfer. The net effect of this leakage will be to leave a small percentage of the dilution water in tank 241-SY-101. 


\subsection{OPERATIONS PLAN}

\subsection{INITIAL PUMP P-350 INSTALLATION AND STANDBY LINE-UP MAINTENANCE}

Current project planning calls for installation of the transfer pump P-350 in tank 241-SY-101 several months before system start-up and the commensurate operation of pump P-350. A significant concern is the affect this period of inactivity will have on this pump as it is submerged in a warm, high density, saturated salt solution in equilibrium with a sizeable mass of precipitated salts. Upon pump P-350 installation, the transfer line should be back-flushed and a hydraulic lock placed on the P-350 discharge leg to insure the pump column and pump itself is filled with fresh water. This should limit the mechanisms by which concentrated waste could enter the pump internals to that of static mass diffusion. The back-flush should also be performed prior to any operation of the transfer pump. The back-flush will minimize the exposure of the pump internals and piping to the waste during periods when the transfer system is in the standby line-up. Additionally, periodic P-350 purges should be performed.

The manufacturer recommends that the pump be installed with authorization to operate at very low speed to free the internals of crystallized waste, yet preclude developing enough head for fluid to reach the top of the pump column. In lieu of this operation, a bi-weekly flush of two P-350 pump internal and column volumes (approximately 50 gallons) is recommended until it can be demonstrated that pump operation is not affected by this proposed mechanism of solids precipitation in the pump internals. A hydraulic lock should be placed on the P-350 discharge leg following the bi-weekly flush. The manufacturer stated that a lower frequency of purge would be acceptable if the relationship between the purge frequency and rotor breakaway torque could be demonstrated. Such a relationship could only be shown by periodic bumping of the pump, an activity currently disallowed by the Authorization Basis.

The bi-weekly flushing requirement will be reviewed for applicability based upon completion of the following activities:

- The initial waste transfer

- The spare transfer pump is available.

\subsection{A DISCUSSION OF FLOW AND TEMPERATURE MEASUREMENT ERROR}

The operation of the transfer system magnetic flow meters (FE-367, FE-419) will be verified under actual system conditions. The general technique will be to compare the indicated dilution water and waste slurry flow rates and volumes from the respective magnetic flow meters to the volume changes indicated by level rise in tank 241-SY-102. 
Practical level measurement difficulties in tank 241-SY-101 preclude its level change from being used as a volumetric measurement.

An additional part of this test will be to determine the pump P-350 VFD setpoint for the desired steady-state waste transfer slurry flow rate. A minimum transfer rate of $60 \mathrm{gpm}$ is needed to achieve a flow velocity of $6 \mathrm{ft} / \mathrm{sec}$. The dilution water flow can be supplied to the PPP at a rate of up to $70 \mathrm{gpm}$ and should not be less than $20 \mathrm{gpm}$ during transfer operations. The dilution water flow rate measurement is provided with alarms (SY-461-RW-FAL-419 and -FAH-419) to notify the operator when water is supplied to the PPP at flow rates less than $20 \mathrm{gpm}$ or greater than $70 \mathrm{gpm}$. These alarm setpoints are $25 \mathrm{gpm}$ and $65 \mathrm{gpm}$ to account for inaccuracies in the alarm circuitry (Hickman 1999).

While not to exceed $70 \mathrm{gpm}$, efficient operation indicates a steady state dilution water flow rate close to the high capacity limit is desired. The desired DR is one part waste to one part water by volume. At a dilution water flow rate of $60 \mathrm{gpm}$, the allowed waste flow rate would range between $30 \mathrm{gpm}$ and $120 \mathrm{gpm}$ within dilution limits. This would result in a transfer flow rate of $90 \mathrm{gpm}$ to $180 \mathrm{gpm}$. Therefore, specifying a dilution water flow rate of $60 \mathrm{gpm}$ and a transfer flow rate of $120 \mathrm{gpm}$ is a good balance between transfer efficiency and operating margin. The pump P-350 VFD should be set to produce a $120 \mathrm{gpm}$ flow rate through FE-367 at the $60 \mathrm{gpm}$ dilution water flow rate.

Additional considerations are required for the magnetic flow meters used in the transfer operations. These are the accuracies of the installed flow-rate displays available to the Farm Control Panel (SY101-WT-CP-350A) operator. These accuracies are rounded to the next highest integer gpm flow rate as determined from the project instrument setpoint basis document (Hickman 1999). This results in accuracies of $\pm 3 \mathrm{gpm}$ for FQIT-419 and $\pm 16 \mathrm{gpm}$ for FQIT-367. It is noted that more accurate flow-rate indications are available within these instrument loops, but these indications are not readily accesible to the operator at the valve and instrument control stand.

Although it is expected that any bias in the two flow instruments will be in the same direction, this cannot be assured. Therefore, an actual dilution ratio (DR) value could be significantly different from the indicated DR value:

Indicated: $\quad \mathrm{DR}=\frac{\mathrm{FQIT}-419}{\mathrm{FQIT}-367}=\frac{60 \mathrm{gpm}}{120 \mathrm{gpm}}=0.50$

Actual: $\quad \mathrm{DR}=\frac{60 \pm 3 \mathrm{gpm}}{120 \pm 16 \mathrm{gpm}}=0.42$ to 0.61

Indicated: $\quad \mathrm{DR}=\frac{\mathrm{FQIT}-419}{\mathrm{FQIT}-367}=\frac{30 \mathrm{gpm}}{60 \mathrm{gpm}}=0.50$ 
Actual: $\quad \mathrm{DR}=\frac{30 \pm 3 \mathrm{gpm}}{60 \pm 16 \mathrm{gpm}}=0.27$ to 0.75

Additionally, there are volumetric flow (i.e., critical velocity) concerns arising from the inaccuracy of the FQIT-367 indication:

Indicated: $\quad$ FQIT-367 $=60 \mathrm{gpm}$

Actual: $\quad$ FQIT-367 $=44 \mathrm{gpm}$

These considerations combine to show that in order to maintain $>6 \mathrm{ft} / \mathrm{sec}$ in the transfer line and ensure that the dilution ratio limits are satisfied in the presence of these flow rate measurement errors, steady state operations during waste transfer should strive to:

1) maintain the indicated flow rate on FQIT-367> $80 \mathrm{gpm}$

2) maintain the value of $D R$ as close to 0.5 as possible.

This recommendations should ensure that, over a reasonably steady a period of waste transfer operations, the transfer line critical velocity will be satisfied and that the low dilution limit of one-part water : two-parts waste $(\mathrm{DR}=0.33)$ will not be violated:

$(80-16) \mathrm{gpm}=64 \mathrm{gpm} \rightarrow \mathrm{v}>6 \mathrm{ft} / \mathrm{sec}$

$\mathrm{DR}=\frac{40-3 \mathrm{gpm}}{80+15 \mathrm{gpm}}>0.33$

It is noted that if a transfer line flow rate of less than $80 \mathrm{gpm}$ is used, the indicated DR should be maintained above 0.50 to ensure that the actual DR does not drop below 0.33 .

This process control dilution/flush water temperature range of $102{ }^{\circ} \mathrm{F}$ to $130^{\circ} \mathrm{F}$ must be adjusted to account for the TI-373 loop inaccuracy. This inaccuracy is specified to the nearest integer temperature as $\pm 8{ }^{\circ} \mathrm{F}$. Therefore the water supply temperature as indicated on TI-373 at the instrumentation and valve control stand should be maintained between $102{ }^{\circ} \mathrm{F}$ and $130{ }^{\circ} \mathrm{F}$ to ensure that water of at least $102{ }^{\circ} \mathrm{F}$ and not more than $130^{\circ} \mathrm{F}$ is supplied to the PPP.

However, it should be noted that the instrument loop 373 drives the dilution water low temperature alarms (SY101-WT-TAL-373A and B). The uncertainty of these alarms is $\pm 4^{\circ} \mathrm{F}$ (Hickman 1999). With this consideration, it may be prudent to try to maintain dilution water temperature as indicated on TI-373 so as not to interfere with these alarms. 


\subsection{TRANSFER SYSTEM PREHEAT}

Immediately prior to waste transfer operations, those portions of the transfer line that will see waste slurry are preheated by performing a heated water flush and by use of the transfer line heat tape. These line sections include the transfer line, the P-350 pump discharge line, and the P-350 pump internal purge path. Therefore, prior to waste transfer activities, each of these three sections of process piping are flushed in sequence for two minutes per section. The flush flow rate is specified to be up to $60 \mathrm{gpm}$, with $60 \mathrm{gpm}$ being the target flow rate. The actual flow rate achievable may be less because of the flow restriction in that leg of piping (i.e., pump P-350 internals). These flushes will add assurance against solids precipitation upon transfer start-up.

Once the system lines have been preheated, transfer operations must begin before the PPP low water temperature alarm (TAL-373A/B) activates, or the preheat operation must be repeated.

\subsection{SYSTEM STARTUP MANAGEMENT PLAN}

The system startup management plan uses a process of developing an operational experience base during the initial operation of the transfer system. The basic mechanics of the system operation are covered by the Acceptance, Operational, and Functional Test Procedures. The system startup management plan accomplishes a number of goals for transfer system operations. These include

- Magnetic Flow Meter Installed Operation

- Operational Flammable Gas, Ammonia, and VOC Emissions

Ammonia is indicated as being an extensive problem for the tank 241-SY-101 transfer effort (Hedengren 1999). The estimated ammonia concentrations in tank 241-SY-101 waste, and the estimated behavior of ammonia in those wastes when exposed to air, has driven incorporation of the ASSD into the transfer system. The primary purpose of the ASSD is to minimize the direct contact of tank 241-SY-101 convective wastes with tank atmosphere.

At the beginning of the initial transfer, particular attention will be paid to the off gassing from both tanks. This will add confidence that adverse or otherwise difficult to control gas concentrations and emissions are unlikely to occur during the waste transfer

\subsection{TRANSFER OPERATIONS}

The transfer system is designed to be a simple, robust system to minimize training requirements and the probability of component/interface requirements that could compromise the system's operating reliability. 


\subsubsection{Transfer Start-Up}

In order to initiate a waste transfer from tank 241-SY-101 to tank 241-SY-102, the waste level in tank 241-SY-102 must be greater than 170 inches ( $468 \mathrm{kgal})$ to limit ammonia emissions from the surface of the supernate. Additionally, this level cannot exceed 270 inches $(750 \mathrm{kgal})$ in order to provide reserve operational volume for ongoing saltwell pumping activities. This adds the constraint that the small waste transfer at a nominal 1:1 water dilution cannot result in exceeding a tank 241-SY-102 level of 393 inches.

Initiating the waste transfer operations refers to the transition from the Stand-By configuration to the transfer operation configuration. This transition is achieved by first warming any section of system piping which, if not performed, could subject tank wastes to temperatures below $102{ }^{\circ} \mathrm{F}$. This preheat is accomplished by performing three system flushes/preheats in rapid succession. These are:

(1) Transfer Line Flush or Preheat (Section 4.2.2)

(2) Transfer Line Back-Flush or Preheat (Section 4.2.3)

(3) Pump P-350 Purge (Section 4.2.4)

Next, the Waste Transfer (Section 4.2.8) is established. To do this, the dilution water flow is established by the appropriate valve line-up. Throttle valve V-410 at the FCP is adjusted to the desired dilution water flow rate of $60 \mathrm{gpm}$. Pump P-350 is then started at a pre-selected speed. It is anticipated that the starting speed is less than the optimum transfer speed, and so pump speed must be adjusted to obtain the desired slurry transfer flow rate. The specifications of the transfer system state that at no time during standard transfer operations can the waste transfer flow rate exceed twice the dilution water flow rate. Therefore, the transfer flow rate for the waste/dilution water mixture should never exceed three times the dilution water flow rate.

\subsubsection{Controlled Transfer Shut-Down}

A controlled system shutdown is essentially the reverse of the transfer start-up. The idea is to adjust dilution water and pump P-350 flow rates to minimize the waste concentration in the transfer line prior to stopping pump P-350. Once the maximum dilution has been achieved in the transfer line and pump P-350 has been shut down, the three standard system flushes are performed followed by placing the system in the System Standby lineup (Section 4.2.1). The operations required to return the transfer system to the Stand-By condition are:

(1) Transfer Line Flush or Preheat (Section 4.2.2)

(2) Pump P-350 Discharge Line Flush or Preheat (Section 4.2.3)

(3) Pump P-350 Purge (Section 4.2.4)

(4) Perform the Siphon Break Valve Operations 
(5) Establish the Stand-By Configuration (Section 4.2.1)

In order to minimize waste concentrations in the transfer line in preparation to shut down pump P-350, the dilution water flow rate is set to at least $60 \mathrm{gpm}$. Next, the speed of pump P-350 is slowly adjusted downwards until the transfer line flow rate is $60 \mathrm{gpm}$ (or equal to the dilution water flow rate). Once the $60 \mathrm{gpm}$ transfer flow rate is achieved and maintained for a few minutes, pump P-350 can be stopped.

\subsubsection{Off-Normal Transfer Shut-Down and Flushing}

Off-Normal transfer shut down and flushing, with a loss of normal flushing capability, is the evolution that uses ACC-401 on the WSS. This accumulator and its supporting equipment are used to respond to a major upset condition that requires the uncontrolled shut down of pump P-350. This condition might result from a loss of process water, a loss of electric power, or detection of high airborne contaminant concentrations. The objective is to clear the transfer line of wastes and this is achieved by flushing this line to both tanks 241-SY-102 and 241-SY-101. This is achieved by performing the ACC-401 Transfer Line Flush (Section 4.2.6).

At this point, the valve operation to establish a siphon break is performed followed by returning the transfer system to the Stand-By line-up (Section 4.2.1). The flush of the transfer line using ACC-401 need only be performed once, since normal operation of the water skid must be established before ACC-401 can be refilled.

\subsubsection{Tank Farm Access Considerations during Transfer Operations}

The design of the flexible hose-in-hose arrangement of the transfer line and its lead blanket shielding offers no structural protection from vehicular contact. Because of the susceptibility of the transfer system to vehicular damage, as a minimum, the control provided by TSR AC 5.10.2.b (LMHC 1999c) must be followed. This control begins at the time of transfer line installation and not just during transfer operations.

During transfer operation, the over-ground transfer line will be a source of ionizing radiation not normally present in the tank farm. This transfer line and certain associated structures will be posted as a high-radiation area. Personnel access to these locations during transfer operations must consider this fact.

Transfer operations will require operator presence at the water supply valve and instrumentation stand assembly (FCP) and the water support skid electrical enclosure (WSCP). The DACS Instrument Trailer should be monitored during transfer operations. Additionally, operator presence is required at the SY-Farm motor control center (MCC) whenever the speed of pump P-350 must be adjusted. Adequate data logging must be performed periodically per Section 8.4.5. 


\subsubsection{Monitored Parameters for Transfer Operations}

A requirement for transfer operations is for tank 241-SY-101 and -102 temperatures and ENRAF $^{\text {TM }}$ levels and SHMS/GMS gas concentrations to be monitored with regular periodicity by the DACS/TMACS (Tank Monitoring and Control System) system. Additionally, the following process control parameters must be monitored and recorded at 60-minute intervals if data-logging capability is not provided or is not operational for the instrument. These parameters are required for process control, but also have use in subsequent engineering analysis of the transfer operations:

- Tank 241-SY-102 ENRAF ${ }^{\text {TM }}$ level

- Tank 241-SY-101 1-A and 1-C ENRAF ${ }^{\mathrm{TM}}$ levels

- FCP water supply totalized flow (from FE-419).

- WSS water supply totalized flow (from FE-418).

- Transfer line totalized flow (from FQIT-367).

- Tank 241-SY-101 hydrogen concentration (GMS-1/-2)

- Tank 241-SY-101 ammonia concentration (GMS-1/-2)

- Tank 241-SY-102 hydrogen concentration (SHMS-E+)

- Tank 241-SY-102 ammonia concentration (SHMS-E+)

- SY-Farm stack hydrogen concentration (GMS-2)

- SY-Farm stack ammonia concentration (GMS-2)

Additional system parameters are to be recorded for use in subsequent engineering analysis of the transfer operation:

- Pump P-350 VFD output frequency

- Pump P-350 VFD output current

- Pump P-350 VFD output voltage

- Pump P-350 VFD output power factor

\subsection{TANK BACK-DILUTION OPERATIONS}

\subsubsection{Tank Back-Dilution Start-Up}

Start-up of tank back-dilution is equivalent to performing typical flushes of the transfer system within required water flow rate and temperature limits. The flow rate (10 to 60 $\mathrm{gpm}$ ) is controlled with flow control valve $\mathrm{V}-410$. 


\subsubsection{Tank Back-Dilution Shut-Down}

Shut-down of tank back-dilution is performed by shutting flow control valve V-410 and stopping the running water supply pump on the WSS.

\subsubsection{Tank Farm Access Considerations during Tank Back-Dilution Operations}

The design of the flexible hose arrangement of the dilution water line offers no structural protection from vehicular contact. Because of the susceptibility of the dilution system to vehicular damage, as a minimum, the control provided by TSR AC 5.10.2.b (LMHC 1999 c) must be followed.

Tank back-dilution operations will require continuous operator interface at the water supply valve and instrumentation stand assembly (FCP) and the water support skid electrical enclosure (WSCP). The DACS Instrument Trailer should be monitored during transfer operations. Adequate data logging must be performed periodically per Section 8.5.5.

\subsubsection{Monitored Parameters for Tank Back-Dilution Operations}

A requirement for transfer operations is for tank 241-SY-101 and -102 temperatures and ENRAF levels and SHMS/GMS gas concentrations to be monitored with regular periodicity by the DACS/TMACS (Tank Monitoring and Control System) system. Additionally, the following process control parameters must be monitored and recorded at 60-minute intervals if data-logging capability is not provided or is not operational for the instrument. These parameters are required for process control, but also have use in subsequent engineering analysis of the transfer operations:

- Tank 241-SY-101 1-A and 1-C ENRAF levels

- FCP water supply totalized flow (from FE-419).

- WSS water supply totalized flow (from FE-418).

- Tank 241-SY-101 hydrogen concentration

- Tank 241-SY-101 ammonia concentration

- SY-Farm stack hydrogen concentration

- SY-Farm stack ammonia concentration

\subsection{MONITORING AND RESPONSE PLAN}

Table 7-1 provides summary guidance as to the proper response if a monitored parameter is outside its expected range. During the transfer operation, besides the operating staff, representatives from the following organizations will be available and will be able to support process changes as needed. 
Project management

Process Engineering

Operations Management

Cognizant Engineer

Technology Support

These representatives will be knowledgeable of the logic behind the summary tables as well as the supporting analysis that has been performed.

In general if the transfer conditions are outside expected conditions and can not be easily brought into range the transfer will be stopped, the condition evaluated and the necessary adjustments made to maintain control of the condition in the tanks. Tables 7-2 and 7-3 describe the major instruments whose indication may trigger remediation system action.

If the response action is to terminate the waste transfer the following general guidance is provided for system restart:

Following shutdown of the tank 241-SY-101 to tank 241-SY-102 transfer due to abnormal or anomalous tank 241-SY-101 conditions, the Technical Review Group (TRG) will review the tank data. Under these conditions, restart must be authorized by the TRG. Unscheduled meetings may be held to review abnormal occurrences, restarts, changes to procedures, etc; actions shall be ratified at the regular meetings. 
Table 7-1. Transfer System Key Process Control Variables*

\begin{tabular}{|c|c|c|c|c|c|}
\hline Instrument & Description & Low Limit & $\begin{array}{l}\text { Low Limit } \\
\text { Response }\end{array}$ & High Limit & $\begin{array}{l}\text { High Limit } \\
\text { Response }\end{array}$ \\
\hline FQIT-367 & $\begin{array}{l}\text { Transfer Line } \\
\text { Flow Rate }\end{array}$ & $\begin{array}{l}60 \mathrm{gpm} \\
\text { (transfer only) }\end{array}$ & $\begin{array}{l}\text { Increase transfer } \\
\text { flow rate (and } \\
\text { water flow rate if } \\
\text { needed) }\end{array}$ & $\begin{array}{l}210 \mathrm{gpm} \\
\text { (transfer only) }\end{array}$ & $\begin{array}{l}\text { Reduce transfer } \\
\text { pump flow rate }\end{array}$ \\
\hline FQIT-367 & $\begin{array}{l}\text { Totalized } \\
\text { Transfer Line } \\
\text { Flow }\end{array}$ & $\mathrm{N} / \mathrm{A}$ & N/A & $603 \mathrm{kgal}$ & $\begin{array}{l}\text { Place transfer } \\
\text { system in Stand- } \\
\text { By configuration }\end{array}$ \\
\hline FQIT-419 & Water Flow Rate & $\begin{array}{l}20 \mathrm{gpm} \\
\text { (transfer only) }\end{array}$ & $\begin{array}{l}\text { Increase water } \\
\text { flow rate }\end{array}$ & $70 \mathrm{gpm}$ & $\begin{array}{l}\text { Reduce water } \\
\text { flow rate }\end{array}$ \\
\hline FQIT-419 & $\begin{array}{l}\text { Totalized Water } \\
\text { Flow }\end{array}$ & N/A & N/A & $402 \mathrm{kgal}$ & $\begin{array}{l}\text { Place transfer } \\
\text { system in Stand- } \\
\text { By configuration }\end{array}$ \\
\hline TI-373 & $\begin{array}{l}\text { PPP Water } \\
\text { Supply } \\
\text { Temperature }\end{array}$ & $102^{\circ} \mathrm{F}$ & $\begin{array}{l}\text { Take actions to } \\
\text { prevent solids } \\
\text { precipitation in } \\
\text { transfer line } \\
\text { (see Notes) }\end{array}$ & $130^{\circ} \mathrm{F}$ & $\begin{array}{l}\text { Take actions to } \\
\text { prevent, or } \\
\text { minimize the } \\
\text { volume of, } \\
\text { excessively hot } \\
\text { water entering } \\
\text { tank } \\
241-S Y-101\end{array}$ \\
\hline PI-368 & $\begin{array}{l}\text { Transfer Line } \\
\text { Pressure } \\
\text { Indication }\end{array}$ & N/A & N/A & $\begin{array}{l}>15 \text { psig } \\
\text { increase per hour } \\
\text { or day (at } \\
\text { constant transfer } \\
\text { line flow rate) }\end{array}$ & $\begin{array}{l}\text { Notify shift } \\
\text { manager for } \\
\text { evaluation }\end{array}$ \\
\hline
\end{tabular}

Notes: Transfer system corrective actions may include:

- increase/decrease water supply flow rate and/or temperature to the WSS

- increase/decrease water supply flow rate to the PPP

- increase/decrease transfer line flow rate to tank 241-SY-102

- energize/deenergize applicable water-skid heat traces

- energize/deenergize PPP water supply hose heat trace

If the waste transfer system operation cannot be readily brought back into control by some combination of the above corrective actions, the activity will be terminated and the transfer system placed in the Stand-By configuration (Section 4.2.1). Where circumstances permit, a controlled transfer shutdown (Section 7.5.2) would be preferred over an off-normal transfer shutdown (Section 7.5.3).

Other transfer system instrumentation exists, but these instruments are not used as primary process control indications. However, this additional instrumentation may be used to initiate corrective actions on the transfer system. Tables 6-5 through 6-9 provide a listing of these system specific instruments, their process and instrument response ranges, and alarm setpoints (where applicable).

The instrumentation listed in this table are the most time critical for the RAPID transfer system. As such, upset conditions must be addressed quickly or the onset of functional impairment of the transfer system could rapidly develop. 
Table 7-2. Existing SY-Farm Level Instrumentation

\begin{tabular}{|c|c|c|c|c|c|}
\hline Instrument & Description & Low Limit & $\begin{array}{l}\text { Low Limit } \\
\text { Response }\end{array}$ & High Limit & $\begin{array}{l}\text { High Gimit } \\
\text { Response }\end{array}$ \\
\hline $\begin{array}{l}\text { tank 241-SY- } \\
102 \text { ENRAF'M }\end{array}$ & Waste level & 170 inches & $\begin{array}{l}\text { Do not initiate } \\
\text { transfer until } \\
\text { tank level }>170 \\
\text { inches }\end{array}$ & 393 inches & (1) \\
\hline $\begin{array}{l}\text { tank 241-SY- } \\
1011-A \\
\text { ENRAF }^{T M}\end{array}$ & Waste level & (2) & (1) & (1) & (1) \\
\hline $\begin{array}{l}\text { tank 241-SY- } \\
\text { 101 1-C } \\
\text { ENRAF'M }\end{array}$ & Waste level & (1) & (1) & (1) & (1) \\
\hline $\begin{array}{l}\text { tank } 241-S Y- \\
101 \text { in-tank } \\
\text { video } \\
\text { camera }\end{array}$ & Waste level & (1) & (1) & (1) & (1) \\
\hline $\begin{array}{l}\text { tank } 241-S Y- \\
102 \text { waste level } \\
\text { change } \& \text { FQIT- } \\
367 \text { reading }\end{array}$ & $\begin{array}{l}\text { Material Balance } \\
\text { for Leak } \\
\text { Detection }\end{array}$ & N/A & N/A & (3) & (4) \\
\hline
\end{tabular}

Notes:

(1) Terminate waste transfer and place the system in the Stand-By configuration.

(2) The waste level measurements and observations in tank 241-SY-101 are not provided with any quantitative limits, but rather, to indicate the occurrence of any "step changes" larger than those associated with the slow rate of waste removal. Such changes would indicate the occurrence of discrete events of significant size, which are associated with negative connotations for control of the waste behavior. Examples could be:

- Indication of a sudden release of a sizeable gas volume due to a short term level drop that is much more rapid than the steady rate of waste removal.

- Indication of a sudden release of a sizeable gas volume due to the observation of significant splashing or splattering.

- Indication of crust bridging or adhesion due to lack of a steady level drop or video evidence of significant crust cracking or shifting. It is expected that the observers (Operations Management, Process Engineering, Project Management, etc) will evaluate the relative rates of level change with respect to the pumping rate in tank 241SY-101. If the bridging approaches 5 inches less level drop than waste removed the transfer will be shutdown and the conditions monitored/evaluated until the waste surface settles to nearly balance transfer out or the TRG has an adequate understanding of the reason for the abnormal condition. Video evidence of crust cracking or shifting will be evaluated against similar guidelines but will also be compared to the headspace gas concentration as reported in DACS.

(3) [tank 241-SY-102 current waste level - tank 241-SY-102 initial waste level] x 2,750 gal/in - FQIT-367

$$
\begin{aligned}
& \leq 1400 \text { gal @ } 30 \text { minutes } \\
& \leq 1400 \text { gal @ } 60 \text { minutes } \\
& \leq 2000 \text { gal } @ 22 \text { hours }
\end{aligned}
$$

(4) Inspect leak detectors and transfer line. If leak is detected, terminate waste transfer and place the system in the Stand-By configuration. 
Table 7-3. Existing SY-Farm Gas Monitoring Instrumentation

\begin{tabular}{|c|c|c|c|c|c|}
\hline Instrument & Description & Low Limit & $\begin{array}{l}\text { Low Limit } \\
\text { Response }\end{array}$ & Aigh Limit & Olingh Linit \\
\hline $\begin{array}{l}\text { SY-Farm } \\
\text { GMS-1 and } \\
\text { GMS-2 }\end{array}$ & $\begin{array}{l}\text { Tank } 241-S Y- \\
101 \text { hydrogen } \\
\text { concentration }\end{array}$ & N/A & N/A & $\begin{array}{l}6900 \mathrm{ppm} \\
\text { (alarm setpoint } \\
\text { to anticipate the } \\
25 \% \text { LFL } \\
\text { condition) }\end{array}$ & (1) \\
\hline $\begin{array}{l}\text { SY-Farm } \\
\text { GMS-2 }\end{array}$ & $\begin{array}{l}\text { Tank 241-SY- } \\
101 \text { ammonia } \\
\text { concentration }\end{array}$ & N/A & N/A & $3000 \mathrm{ppm}$ & (1) \\
\hline $\begin{array}{l}\text { SY-Farm } \\
\text { SHMS-E+ } \\
\text { (local } \\
\text { indication) }\end{array}$ & $\begin{array}{l}\text { Tank 241-SY- } \\
102 \text { hydrogen } \\
\text { concentration }\end{array}$ & N/A & N/A & $\begin{array}{l}6250 \mathrm{ppm} \\
\text { (alarm setpoint } \\
\text { to anticipate the } \\
25 \% \mathrm{LFL} \\
\text { condition) }\end{array}$ & (1) \\
\hline $\begin{array}{l}\text { SY-Farm } \\
\text { SHMS-E+ (local } \\
\text { indication) }\end{array}$ & $\begin{array}{l}\text { Tank 241-SY- } \\
102 \text { ammonia } \\
\text { concentration }\end{array}$ & N/A & N/A & $3000 \mathrm{ppm}$ & (1) \\
\hline $\begin{array}{l}\text { SY-Farm } \\
\text { GMS-2 }\end{array}$ & $\begin{array}{l}\text { SY-Farm } \\
\text { ventilation stack } \\
\text { ammonia } \\
\text { concentration }\end{array}$ & N/A & N/A & $1000 \mathrm{ppm}$ & (1) \\
\hline \multirow{2}{*}{$\begin{array}{l}\text { IH Portable } \\
\text { Ammonia } \\
\text { Monitor }\end{array}$} & \multirow{2}{*}{$\begin{array}{l}\text { SY-Farm } \\
\text { area/ground } \\
\text { ammonia } \\
\text { concentration }\end{array}$} & \multirow[t]{2}{*}{ N/A } & \multirow[t]{2}{*}{ N/A } & $25 \mathrm{ppm}$ & (2) \\
\hline & & & & $250 \mathrm{ppm}$ & (3) \\
\hline \multirow[t]{2}{*}{$\begin{array}{l}\text { IH Portable } \\
\text { VOC Monitor }\end{array}$} & \multirow{2}{*}{$\begin{array}{l}\text { SY-Farm } \\
\text { area/ground } \\
\text { VOC } \\
\text { concentration }\end{array}$} & \multirow[t]{2}{*}{ N/A } & \multirow[t]{2}{*}{$\mathrm{N} / \mathrm{A}$} & $2 \mathrm{ppm}$ & (2) \\
\hline & & & & $25 \mathrm{ppm}$ & (3) \\
\hline
\end{tabular}

Notes:

(1) Terminate waste transfer and place the system in the Stand-By configuration.

(2) Respiratory protection required in-farm.

(3) Detection of $250 \mathrm{ppm}$ ammonia or $25 \mathrm{ppm}$ VOC at ground level requires immediate transfer system shutdown and tank farm evacuation.

(4) In-Tank gas monitoring may be the only effective means to indicate the onset of an upset conditions. Even if gas concentration levels are well below the limits of this table, particular attention will be paid to the dynamic variations in the values as indicators of the need for process control actions. 


\subsection{OFF- NORMAL CONDITIONS}

\subsection{HIGH TANK HEADSPACE FLAMMABLE GAS CONCENTRATION}

A safety control imposed upon the transfer operation is the flammable gas concentration control limit of $25 \%$ of the LFL (equivalent to $6,900 \mathrm{ppm}_{2}$ in tank 241-SY-101 and $6,250 \mathrm{ppm} \mathrm{H}_{2}$ in tank $241-\mathrm{SY}-101$ or the SY-Farm stack). The safety action is to initiate immediate shutdown of transfer operations. However, good operating practice will dictate that significant control action be taken long before this concentration is achieved if the flammable condition is the result of a controlled release. Any process change that results in a significant headspace flammable gas concentration increase or rate of concentration increase should warrant immediate operator response to counter the change. Depending upon which tank is experiencing the change, the corrective action should be to either reduce the rate of water addition, reduce the rate of waste transfer, or both. If flammable gas concentrations do not respond to input corrective actions, the transfer will be terminated at $25 \%$ of the LFL.

\subsection{EXCESSIVE SY-FARM VENTILATION SYSTEM AMMONIA OR VOC EMISSIONS}

This condition is the result of the agitation and chemical alteration of the tank 241-SY-101 wastes as they commingle with the wastes in tank 241-SY-102. The condition is defined as 3,000 ppm NH 3 in tank 241-SY-101 headspace or $1000 \mathrm{ppm} \mathrm{NH}_{3}$ in the SY-Farm stack. Therefore, the recovery action will be either a controlled reduction of the rate or shutdown of tank 241-SY-101 waste transfer. Ideally, if a correlation between the rate of waste transfer and concentration of off gases can be demonstrated, the corrective action for an undesired gas concentration or rate of concentration change may be to reduce the rate of waste transfer. A reduction in the rate of waste transfer would be preferable to a controlled shutdown of transfer operation. A controlled shutdown is preferable to an evacuation of the tank farm with the consequent shutdown of the transfer system.

ESH\&QA (Environmental, Safety, Health, and Quality Assurance) Ammonia and VOC Monitoring in SY-Tank Farm

- Detection of $25 \mathrm{ppm}$ ammonia or $2 \mathrm{ppm}$ VOC at ground level requires mask use in-farm

- Detection of $250 \mathrm{ppm}$ ammonia or $25 \mathrm{ppm}$ VOC at ground level requires immediate transfer system shutdown and tank farm evacuation 


\subsection{LOSS OF SY-FARM PRIMARY VENTILATION}

The concern is uncontrolled build-up of gas and vapor concentrations within the tank headspaces. Initiating a controlled shutdown of the tank 241-SY-101 waste transfer upon loss of ventilation will minimize this buildup.

\subsection{LOSS OF SY-FARM ANNULUS VENTILATION}

The concern is loss of leak detection capability. Limiting condition for operation (LCO) 3.2.6 permits continued operations upon loss of the annulus continuous air monitor if the annulus conductivity probes remain operable. If both annulus leak detection systems are inoperable, a controlled shutdown of the tank 241-SY-101 waste transfer is to be performed in accordance with LCO 3.2.6.

\subsection{LOSS OF ELECTRIC POWER}

The concern of this condition is to minimize the probability of line plugging. In this case, the action is to manually activate the ACC-401 transfer line flush. Once power is restored, the normal sequence of system flushes should be performed as soon as possible.

\subsection{LOSS OF DILUTION WATER}

Upon loss of dilution water supply, the low water supply flow detected at the PPP should trip pump P-350 to minimize the amount of undiluted slurry pumped into the transfer line. If the low water flowrate interlock does not operate properly, the operator response is to stop pump P-350 as soon as possible. This will be immediately followed by a transfer line flush. Once the system water supply is restored, the normal sequence of system flushes should be performed as soon as possible. These actions are designed to minimize the probability of salt precipitation in the transfer line resulting in a line plug.

\subsection{LOSS OF P-350 PUMP}

The normal sequence of system flushes should be performed as soon as possible. This action is designed to minimize the probability of salt precipitation in the transfer line resulting in a line plug.

\subsection{TRANSFER LINE LEAK}

Responses to this condition may be dictated by the severity of the leak. A primary safety concern will be to minimize the amount of a potential environmental release. Upon 
detection of a small-contained leak, a controlled shutdown of the waste transfer system with subsequent water flushes will be specified. Upon a major leak or line break, an immediate P-350 pump shutdown is desired.

\subsection{TRANSFER LINE PLUG}

Recovery from pipeline plugging will utilize heated, pressurized water. Water pressure is gradually cycled on the plug. The slow nature of the pressure cycling prevents packing of the plug. The reapplication of the heated water increases the driving force for dissolution of soluble solids. The pressure can be cycled up to the system rating. If the plug is not immediately removed, the effect is to eventually create a small flow path through the solids plug. Eventually, the flow path will be enlarged through erosion and or dissolution, and the plug should fail under the applied pressure, clearing the line.

This pressurized, heated water can be supplied by either the water supply pumps (P-401 / -402), or the nitrogen pressurized water accumulation tank (ACC-401). Both sources can cycle water pressure to a plug. In the case of the water supply pumps, this can be accomplished with the pressure control valve $\mathrm{PCV}-401$, or for $\mathrm{ACC}-401$, by recharging its air flask. The PPP valve arrangement is such as to allow pressure to be applied to cause flow in the transfer line to either tank.

\subsection{TRANSFER LINE BACK LEAKAGE}

The pressure switches in the PPP (PS-370, PS-371) serve as indications of radioactive wastes leaking into water supply piping. During normal transfer operations, the flush water piping to the transfer line is isolated from:

- the waste flow by valves V-353 and V-354

- the tank headspace by valve V-355

- the dilution water supply by valve V-360

- $\quad$ pump P-350 internals by valve V-361

Therefore, in the valve line-up for transfer operations, this section of PPP piping is isolated. The pressure switch on this section of piping is set to alarm upon detection of $15 \mathrm{psi}$. Upon an alarm, the normal procedures to shutdown, flush and vent the system are performed followed by returning the system to the Stand-By configuration. The cause of the pressure switch activation must be determined and corrected before waste transfer operations can resume. Potential causes of such a condition could be an improper valve line-up, water leak-by at valve V-360 or waste leak-by at valves V-353 or V-354. If the latter, contamination within the PPP piping would also require evaluation and remediation activities. A remediation activity might be repeated flushes (transfer line flush and back flush and pump P-350 purge) through this section of piping. 
HNF-4264 REV. 2

This page intentionally left blank. 


\subsection{REFERENCES}

Antoniak, Z. I., 1998, Thermal Analysis of Tank 241-SY-101 Crust Growth and Partial Retrieval, TWS99.11, Pacific Northwest National Laboratory, Richland, Washington.

Barton, W. B., 1999, Maximum First Transfer and Dilution Volumes for 241-SY-101, RPP-5344, Lockheed Martin Hanford Corporation, Richland, Washington.

Beck, M. A., 1999, "101SY/102SY Composite Boildown," (internal memorandum 82100-99-008), Numatec Hanford Corporation, Richland, Washington.

Erhart. M. F., 1999, Functional Requirements and Technical Criteria for the 241-SY-101 RAPID Mitigation System, HNF-3885, Rev. 0, Lockheed Martin Hanford Corporation, Richland, Washington.

Estey, S. D. 1999, First Revision to Letter of Instruction for Composition Studies on Samples Supporting Tank 241-SY-101 Level Growth Mitigation/Remediation, (internal memorandum 74B50-99-011, to J. R. Jewett, February 8), Lockheed Martin Hanford Corporation, Richland, Washington..

Estey, S. D., and T. A. Hu, 1998, Flow Velocity Analysis for Avoidance of Solids Deposition During Transport of Hanford Tank Waste Shurries, HNF-2728, Rev. 0, Lockheed Martin Hanford Corporation, Richland, Washington.

Fowler, K. D., 1995, Tank Farm Waste Compatibility Program, WHC-SD-WM-OCD-015, Rev. 1, Westinghouse Hanford Company, Richland, Washington.

French, R. T., 1999, Contract No. DE-AC06-96RL13200 - Submittal Of Updated Unreviewed Safety Question (USQ) Evaluation And Supplemental Controls for Tank 241-SY-101, (letter 99-TSD-051 to R. D. Hanson, April 27), U.S. Department of Energy, Office of River Protection, Richland, Washington.

Hedengren, D. C., 1999, Ammonia Concentrations from the Transfer of Waste from Tank 241-SY-101 to Tank 241-SY-102, (internal memorandum 74B40-99-045 to N. W. Kirch, March 11), Lockheed Martin Hanford Corporation, Richland, Washington.

Herting, D. L., 1995, Tank Characterization Report for Double-Shell Tank 24I-SY-10I, WHC-SD-WM-ER-409, Rev. 0, Westinghouse Hanford Company, Richland, Washington. 


\section{HNF-4264 REV. 2}

Hickman, G. L., 1999, Setpoint Calculations for RAPID Project, HNF-4972, Rev 2, Fluor Daniel Northwest, Richland, Washington.

LMHC, 1999a, RAPID Mitigation Transfer Procedure for Pumping Tank 241-SY-101 To Tank 241-SY-102, TO-430-100, Rev./Mod. A-0, Lockheed Martin Hanford Corporation, Richland, Washington.

LMHC, 1999b, River Protection Project Final Safety Analysis Report.

HNF-SD-SAR-067, Rev. 1, Lockheed Martin Hanford Corporation, Richland, Washington.

LMHC, 1999c, Tank Waste Remediation System Technical Safety Requirements, HNF-WM-SD-TSR-006, Rev 0-Q, Lockheed Martin Hanford Corporation, Richland, Washington.

LMHC, 1999d, Tank 241-SY-101 Safety Basis for Remediation Actions and Operations Before Closure of the Unreviewed Safety Question on Waste Surface Change, HNF-3737, Rev. 1, Lockheed Martin Hanford Corporation, Richland, Washington.

Meyer, P. A., and J. R. Biggs, 1999, An Analysis of the Potential for Inadvertent Siphon Flow in the Transfer Line between Tanks 241-SY-101 and 241-SY-102, TWS99.49, Revision 1, Pacific Northwest National Laboratory, Richland, Washington

Meyer, P. A., C. W. Stewart, and C. E. Brennan, 1999, Effects of Crust Ingestion on Mixer Pump Performance in Tank 241-SY-101: Workshop Results, TWS99.58, Pacific Northwest National Laboratory, Richland, Washington

Morris, K. H., 1999, Safety Equipment List for the 241-SY-101 RAPID Mitigation Project, HNF-4531 Rev1, Cogema Engineering, Richland, Washington.

Mulkey, C. H., 1997, Data Quality Objectives for the Waste Compatibility Program, HNF-SD-WM-DQO-001, Rev 2, Lockheed Martin Hanford Corporation, Richland, Washington.

Onishi, Y., and K. P. Recknagle, 1999, SY-101 Slurry Transfer Meeting Minutes, TWS99.23, Pacific Northwest National Laboratory, Richland, Washington.

Person, J. C., 1999, Dilution Studies Of Tank 241-SY-101 Waste. Preliminary Results, (internal memorandum 82100-99-015 to N. W. Kirch, April 22), Numatec Hanford Corporation, Richland, Washington.

Rassat, S. D., P. A. Gauglitz, S. M. Caley, L. A. Mahoney, D. P. Mendoza, 1999, A Discussion of SY-101 Crust Gas Retention and Release Mechanisms, PNNL-12092, Pacific Northwest National Laboratory, Richland, Washington. 
Raymond, R. E., 1999, Tank 241-SY-101 Surface-Level-Rise-Remediation-Project-Plan, HNF-3824, Rev 0, Lockheed Martin Hanford Corporation, Richland, Washington.

Reynolds, D. A., 1998, Prediction of Dilution and Temperature Effects on Waste from Tank 241-SY-101, (internal memorandum 74B50-98-061 to N. W. Kirch, December 15), Lockheed Martin Hanford Corporation, Richland, Washington.

Shook, C. A., and M. C. Rocco, 1991, Slurry Flow: Principles and Practice, Butterworth-Heinemann, Stoneham, Massachusetts.

Steen, F. H., 1999, Compatibility Analysis Results for Tank 241-SY-101 Core Composites, (letter WMH-9951091 to K. M. Hall, February 24), Waste Management Federal Services of Hanford, Inc., Richland, Washington.

Stewart, C. W, 1996, In Situ Rheology and Gas Volume in Hanford Double-Shell Waste Tanks, PNNL-11296, Pacific Northwest National Laboratory, Richland, Washington.

Tingey, J. M, P. R. Bredt, and E. H. Shade, 1994, The Effects of Heating and Dilution On the Rhelogical and Physical Properties of Tank 241-SY-101 Waste, PNL-10198, Pacific Northwest Laboratory, Richland, Washington.

Wagoner, J. D., 1998, Contract Number DE-AC06-96RL13200 - Supplemental Controls for Continued Operations in Tank 241-SY-101 (Letter 98-SCD-140 to R. D. Hanson, FDH), U.S. Department of Energy, Richland Operations Office, Richland, Washington. 
HNF-4264 REV. 2

This page intentionally left blank. 
HNF-4264 REV. 2

APPENDIX A

INDEX OF TECHNICAL OPERATING REQUIREMENTS

A-1 
HNF-4264 REV. 2

This page intentionally left blank.

A-2 
HNF-4264 REV. 2

\section{APPENDIX A}

\section{INDEX OF TECHNICAL OPERATING REQUIREMENTS}

A-1. Basis for Interim Operations (BIO) Controls See Table A-1.0

A-2. Operating Specification Document (OSD) Controls See Table A-2

A-3. Environmental Controls None Identified

A-4. Industrial Safety (Tank Farm HASP) Controls See Table A-3

A-5. Waste Compatibility/Waste Acceptance Controls None Identified

Table A-1. Safety SSCs and TSRs and Defense-in Depth for Representative Accidents. See HNF-3737, Table 12 for these accidents and controls. 


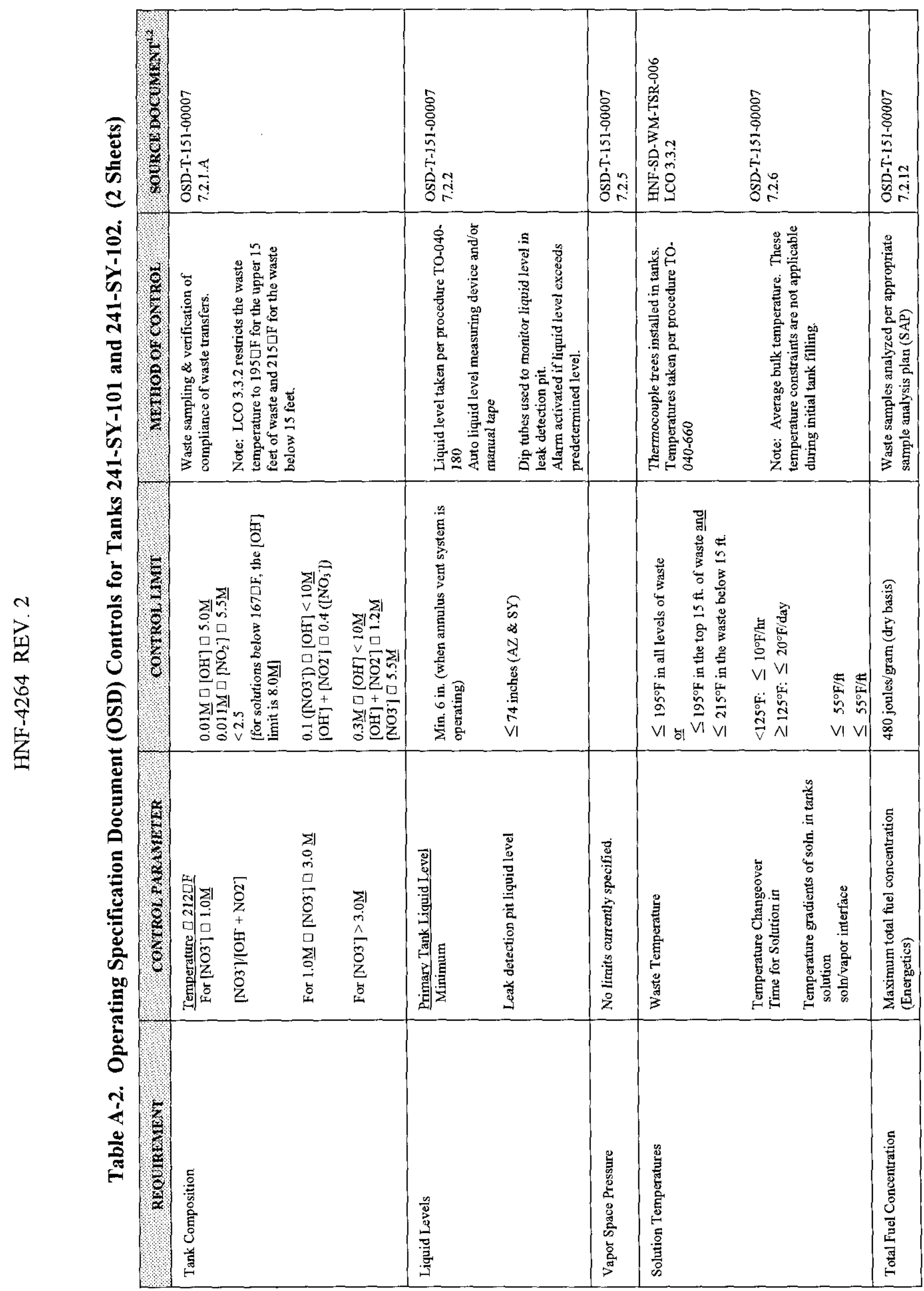




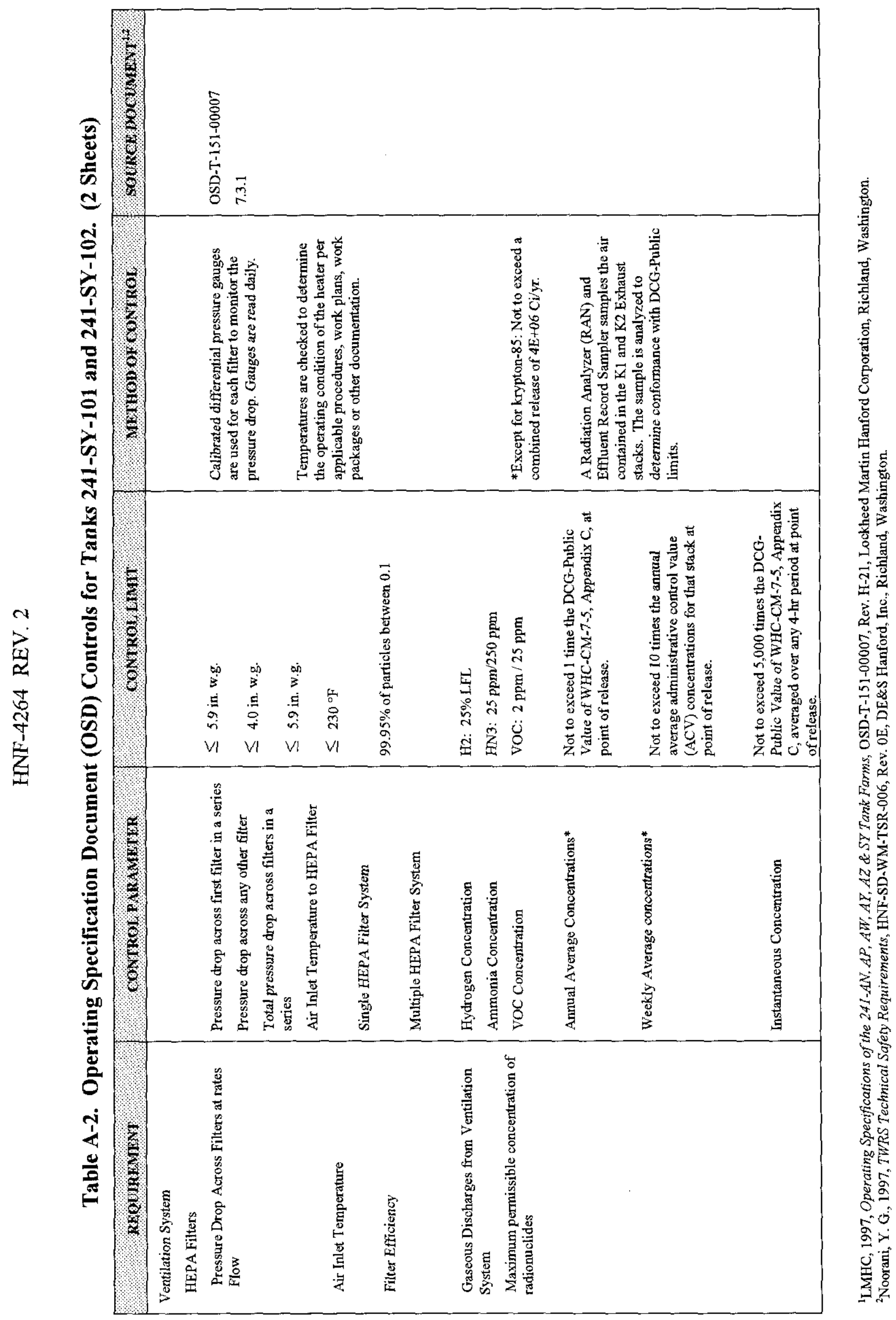

\& 


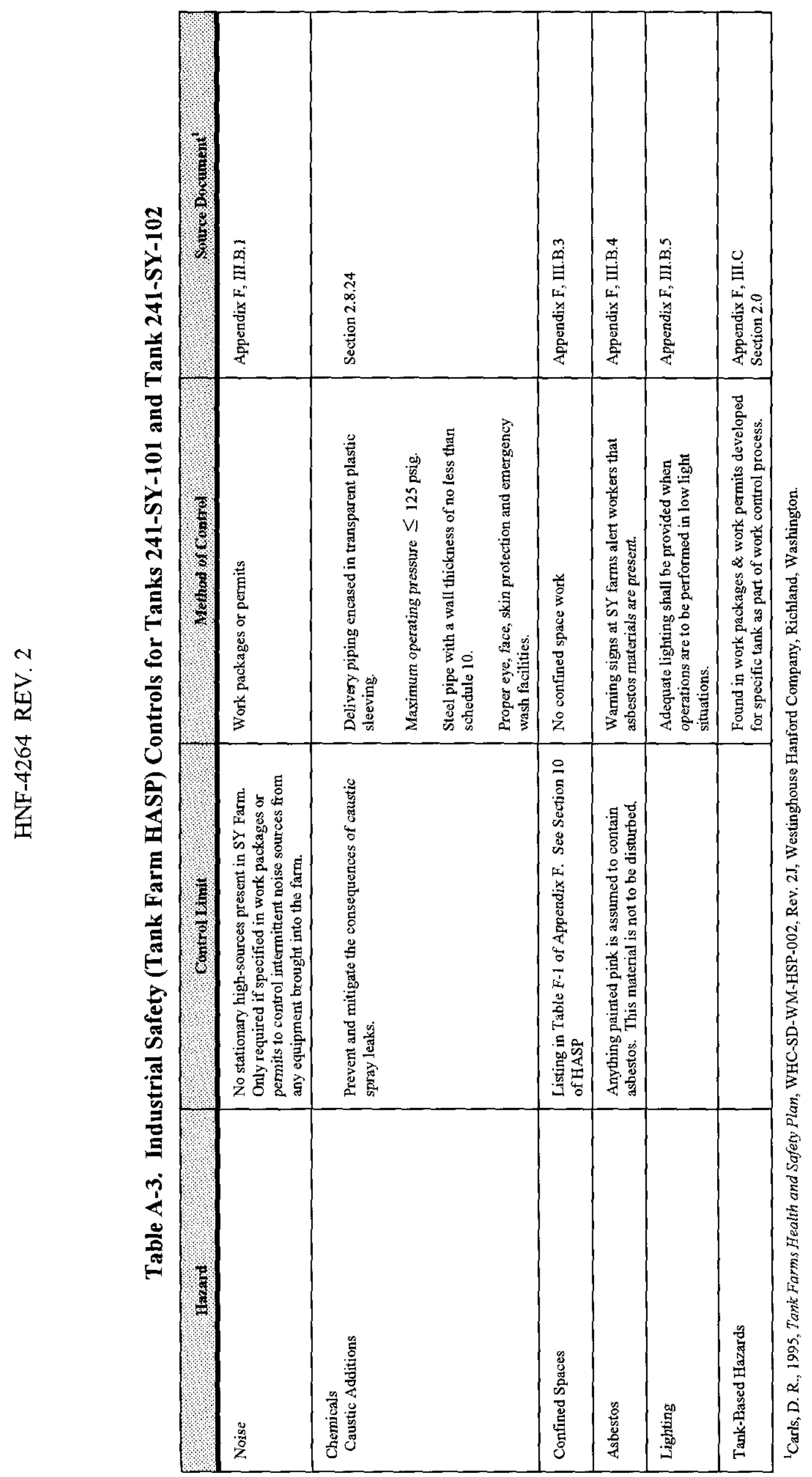

虽 


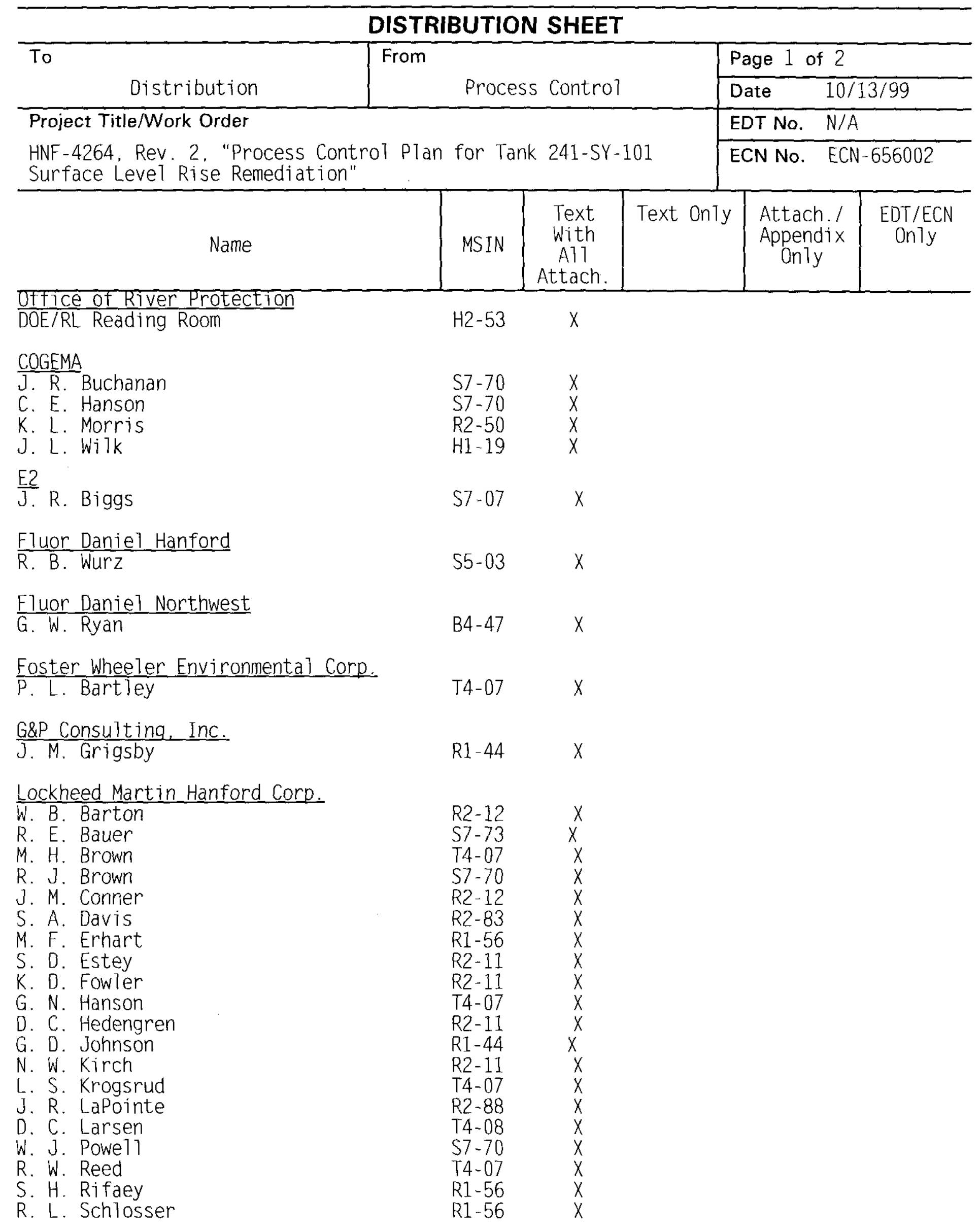




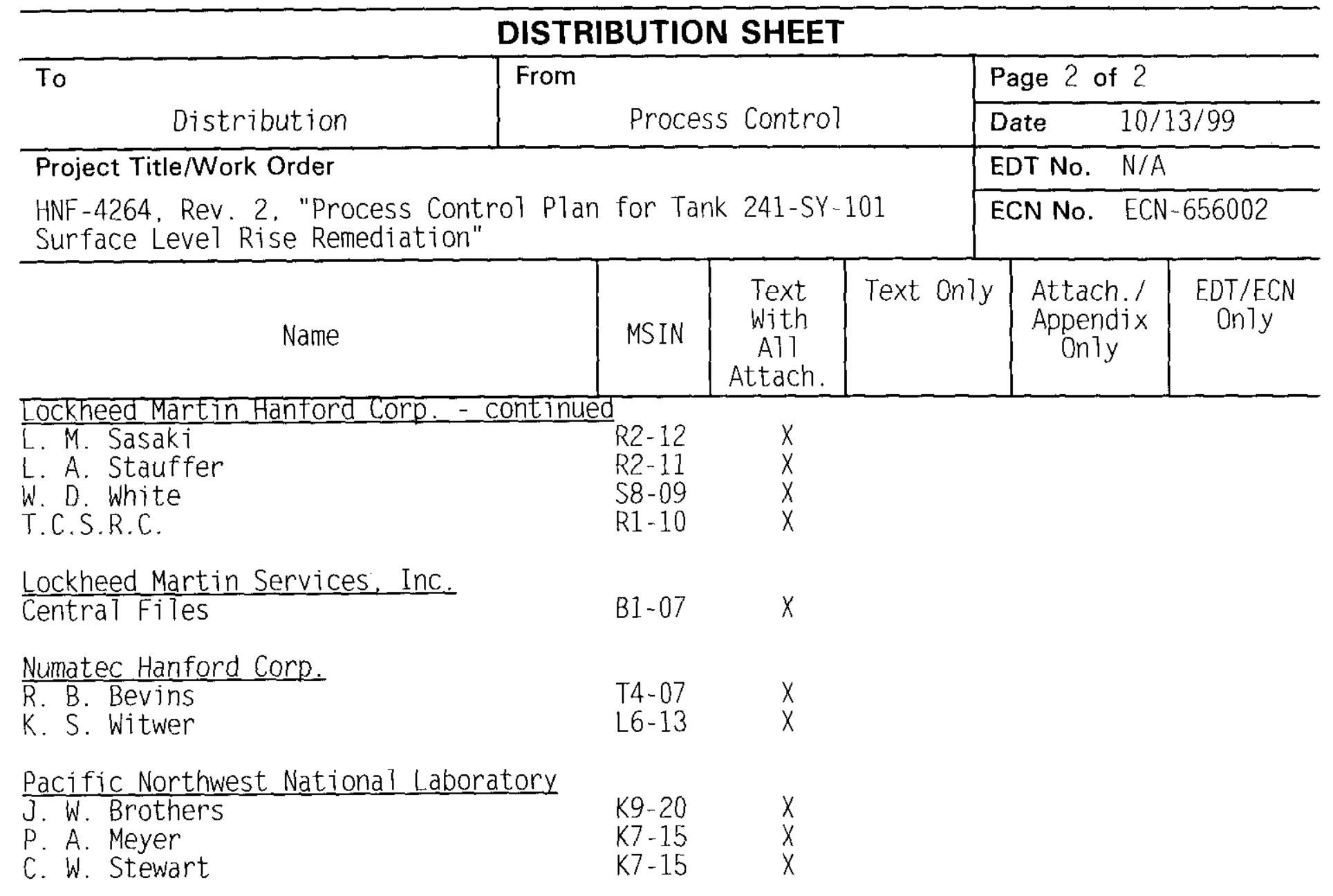

